\title{
Subsurface stratigraphy and depositional controls on Late Devonian-Early Mississippian sediments in southwestern Pennsylvania
}

\author{
Bret A. McDaniel \\ West Virginia University
}

Follow this and additional works at: https://researchrepository.wvu.edu/etd

\author{
Recommended Citation \\ McDaniel, Bret A., "Subsurface stratigraphy and depositional controls on Late Devonian-Early \\ Mississippian sediments in southwestern Pennsylvania" (2006). Graduate Theses, Dissertations, and \\ Problem Reports. 2377. \\ https://researchrepository.wvu.edu/etd/2377
}

This Thesis is protected by copyright and/or related rights. It has been brought to you by the The Research Repository @ WVU with permission from the rights-holder(s). You are free to use this Thesis in any way that is permitted by the copyright and related rights legislation that applies to your use. For other uses you must obtain permission from the rights-holder(s) directly, unless additional rights are indicated by a Creative Commons license in the record and/ or on the work itself. This Thesis has been accepted for inclusion in WVU Graduate Theses, Dissertations, and Problem Reports collection by an authorized administrator of The Research Repository @ WVU. For more information, please contact researchrepository@mail.wvu.edu. 
Subsurface Stratigraphy and Depositional Controls on Late DevonianEarly Mississippian Sediments in Southwestern Pennsylvania

Bret A. McDaniel

Thesis submitted to the Eberly College of Arts and Sciences at West Virginia University in partial fulfillment of the requirements for the degree of

\author{
Master of Science \\ in \\ Geology
}

\author{
Richard Smosna, Ph.D., Chair \\ Thomas Kammer, Ph.D. \\ Richard Goings, M.S.
}
Department of Geology and Geography
Morgantown, West Virginia 2006

Keywords: Murrysville, Cussewago, Weir, Berea, Hundred Foot, Oswayo Shale, Riddlesburg Shale, Southwestern Pennsylvania, Faulting, Rome Trough, Lineaments, Late Devonian, Early Mississippian, Appalachian Basin

Copyright 2006 Bret A. McDaniel 


\section{ABSTRACT \\ Subsurface Stratigraphy and Depositional Controls on Late Devonian-Early Mississippian Sediments in Southwestern Pennsylvania}

\section{Bret A. McDaniel}

Subsurface correlation of well-logs and isopach mapping of Upper Devonian-Lower Mississippian units have been coupled with outcrop measured sections to determine the nature and distribution of Upper Devonian-Lower Mississippian sandstones in southwestern Pennsylvania. The stratigraphic section studied ranges from the Upper Venango Formation to the Price Formation and includes the Hundred Foot, Murrysville (Cussewago / Berea) and Weir sandstones of southwestern Pennsylvania. Isopach maps were generated for the Hundred Foot sandstone, Oswayo Shale, Murrysville sandstone, Riddlesburg Shale, and Weir sandstones as well as eight cross-sections across the study area. The resulting sediment distribution patterns along the developing edge of the Late Famennian-Early Tournaisian foreland basin were dominantly barrier bar, fluvial, braid-delta and shoreface in nature. Evaluation of the isopach geometries suggests that these depositional systems were influenced both by pre-existing structural features and eustatic fluctuations. The author suggests that a strike-parallel structural feature, namely a Rome Trough graben fault, and cross-structural discontinuities (CSDs or lineaments) may have acted as barriers and pathways during sediment deposition in the developing Acadian basin. All three majors sandstones in this study show dramatic facies changes on opposing sides of a southwest-northeast trending Rome Trough basement fault suggesting that this fault may have been active, both in normal and reverse directions, during collisional pulses of the Acadian orogeny. The Devonian Hundred Foot sandstone displays a noticeable thickened section on the west side of the Rome Trough fault, while the Devonian Murrysville sandstone displays a distinct facies change from fluvial to deltaic across the fault. The Mississippian Weir sandstone, in contrast to the Hundred Foot, displays a thickened section on the east side of the basement fault. In addition, northwest-southeast trending CSDs, namely the Blairsville-Broadtop Lineament (B-BL) and the Pittsburgh-Washington Lineament (P-WL), may have influenced fluvial channel positions and acted as sediment traps. Both the Murrysville and Weir sandstones show fluvial channel incision as well as facies changes near these proposed lineaments. 


\section{Acknowledgments}

It has been a long and winding road to finally arrive at this moment, and it is with great thanks and relief to submit this thesis to the Geology and Geography Department of West Virginia University. Like all those that have undertaken this kind of work, I couldn't have completed this research without the guidance and helping hands from others along the way.

Dominion Exploration and Production, Inc. was instrumental in the creation of this idea, for I couldn't have even begun this work without their proprietary well logs, and sample logs. I am grateful to them for allowing this data to be put in thesis form.

A special thanks also goes out to Melissa Tharp, Samuel Billioni and Brenda Snyder for their help with some of the research, figures and material presented here. Their computer and research skills were invaluable.

Thanks to John Harper of the PA DCNR for pointing me in the right direction with reference material and general discussion of the Murrysville, and also to Ron Walden of Dominion Transmission, Inc. for providing me with logs from Oakford Storage in Westmoreland Co. I also want to thanks Texas Keystone, Inc. for providing me a key log for use in this study.

I have also been fortunate to have such a patient and knowledgeable committee behind me. Dick Smosna, Tom Kammer and Rick Goings have made what could have been a difficult process, much easier, with their suggestions and critiques.

To my parents, Gene and Kathy, for their unwavering support and love. And last, but not least, to my wife Luisa, whose patience, understanding, and inspiration (not to mention help with some of the figures) pushed me to the end. I am truly blessed with you at my side. 


\section{Table of Contents}

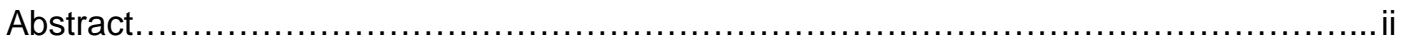

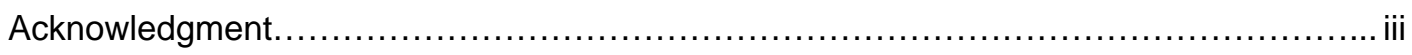

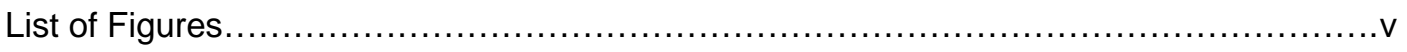

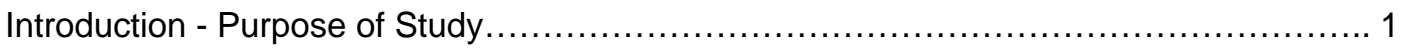

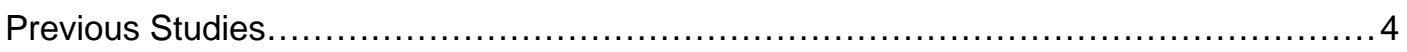

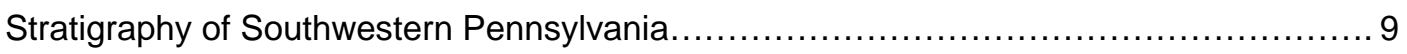

Structural History of Southwestern Pennsylvania........................................ 13

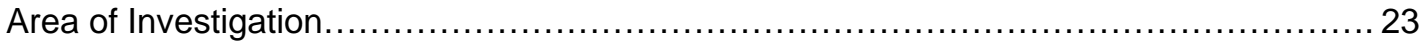

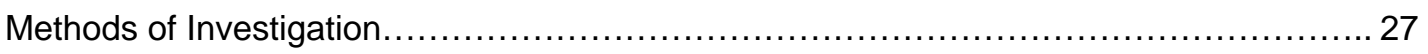

Measured sections at Cramer, PA

Hundred Foot sandstone Section.............................................. 35

Murrysville sandstone Section................................................... 35

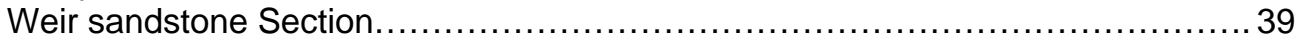

Description and Interpretation of Isopach Maps

Hundred Foot sandstone Isopach.......................................... 42

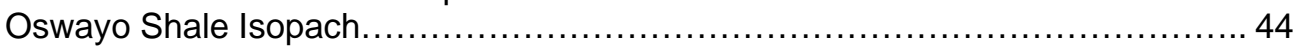

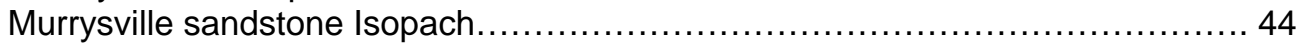

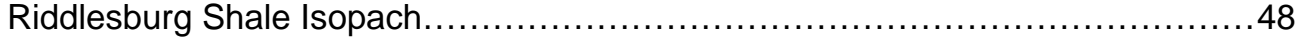

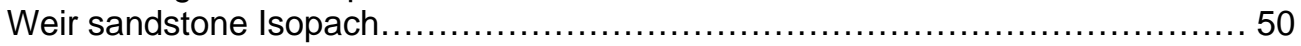

Description and Interpretation of Cross-sections

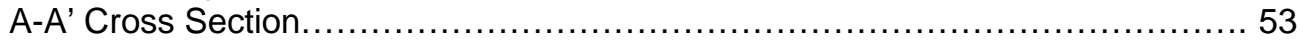

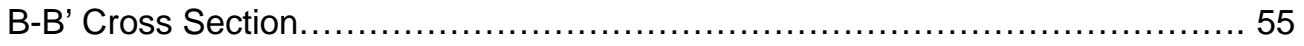

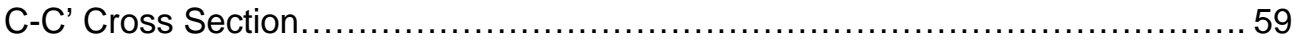

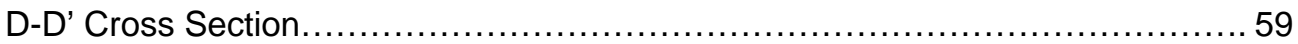

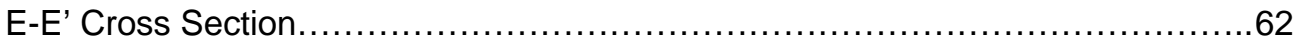

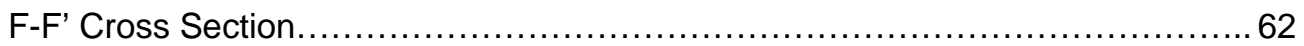

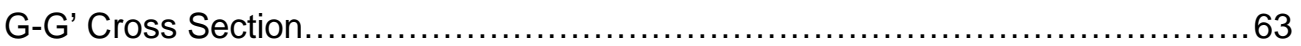

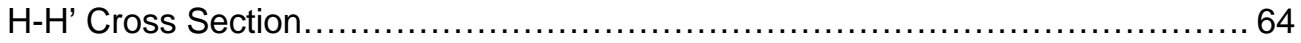

Paleogeography

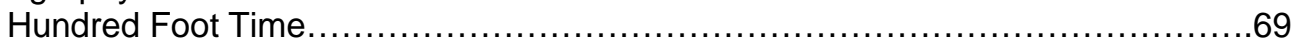

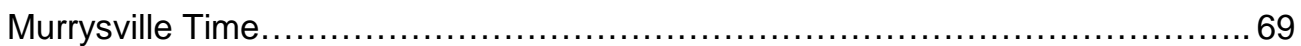

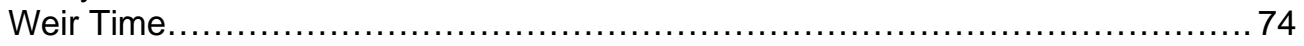

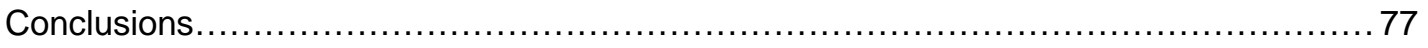

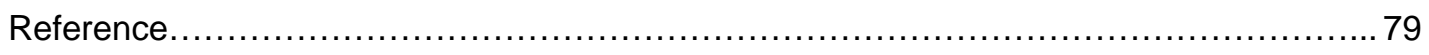

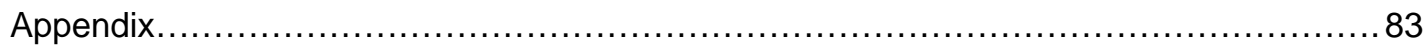




\section{List of Figures}

Figure 1. Stratigraphic formations and drillers' nomenclature within the study area................. 2

Figure 2. Stratigraphic relationships within selected counties of southwestern Pennsylvania....... 5

Figure 3. Regional relationships of the Berea (Murrysville) in the Appalachian Basin............... 7

Figure 4. Interpreted depositional pathways of Berea (Murrysville) sediments.................... 11

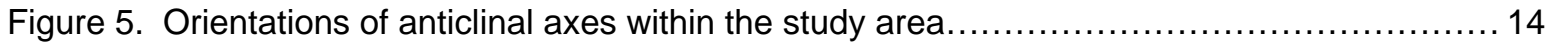

Figure 6. Position of the Rome Trough within the Appalachian Basin .......................... 15

Figure 7 . Orientation of major cross-structural lineaments within the study area $\ldots \ldots \ldots \ldots \ldots \ldots \ldots$

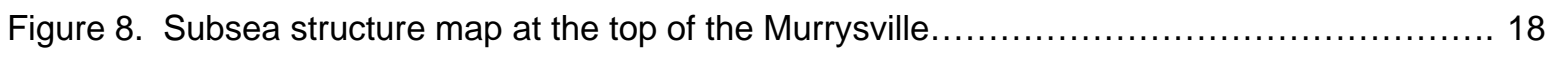

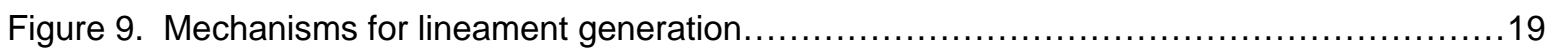

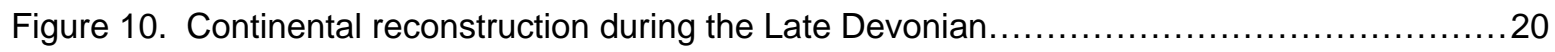

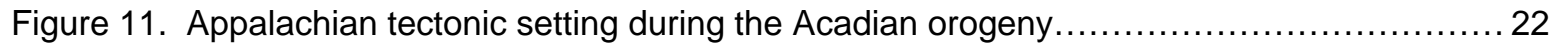

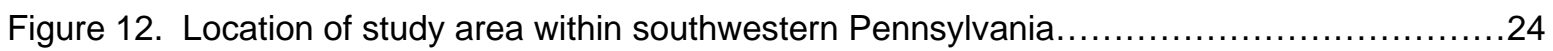

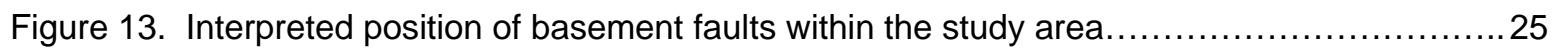

Figure 14. Interpreted position of lineaments within the study area...............................

Figure 15. Location of well log, sample log and outcrop data points used in the study..............28

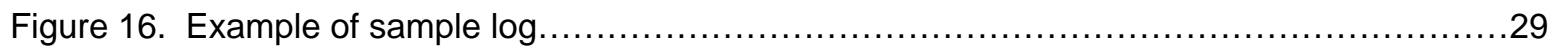

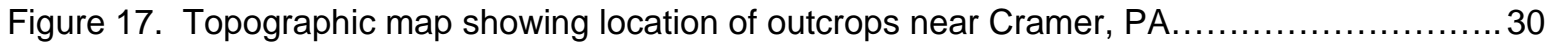

Figure 18. Compensated density type log from Westmoreland County $\ldots \ldots \ldots \ldots \ldots \ldots \ldots \ldots \ldots \ldots \ldots \ldots \ldots \ldots \ldots \ldots$

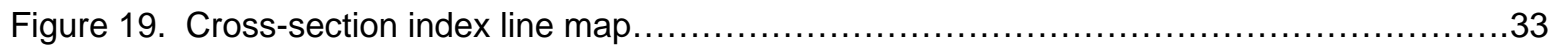

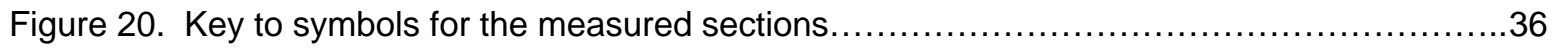

Figure 21. Measured section of the Venango Formation near Cramer, PA....................... 37

Figure 22. Measured section of the Murrysville sandstone near Cramer, PA..................... 38

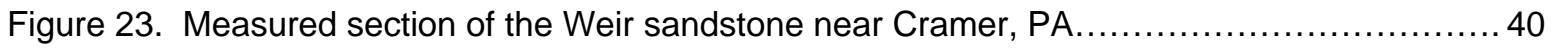

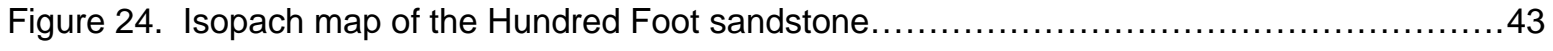

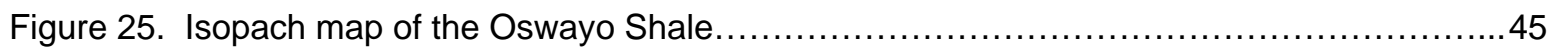

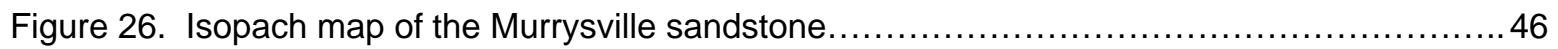

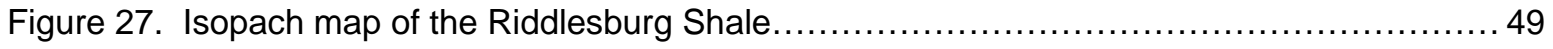




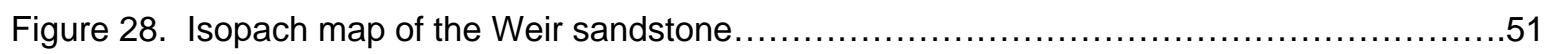

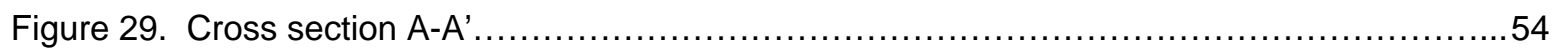

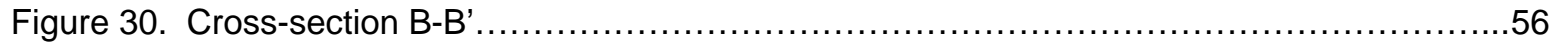

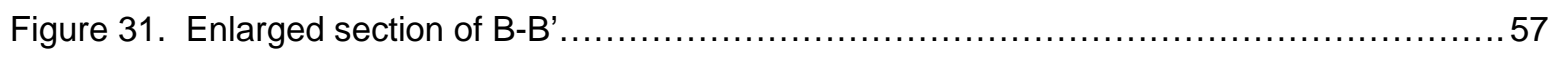

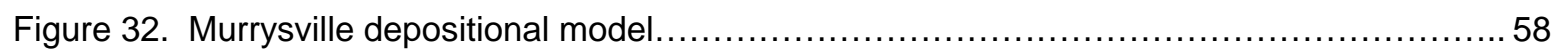

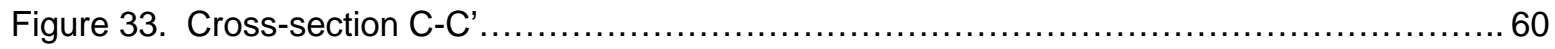

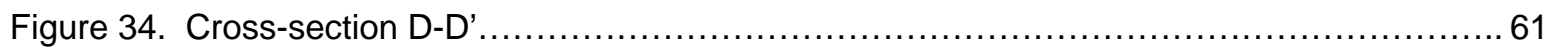

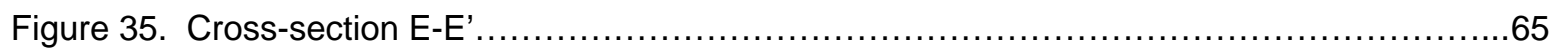

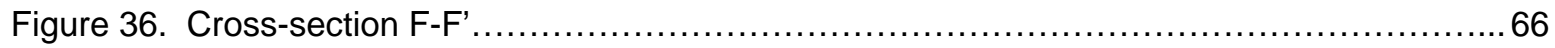

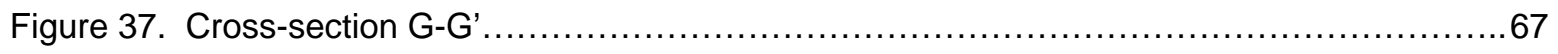

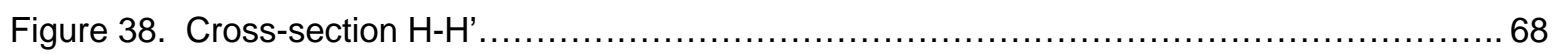

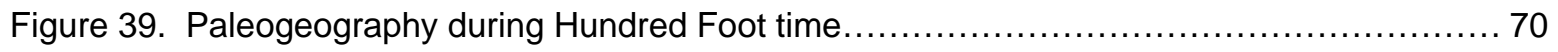

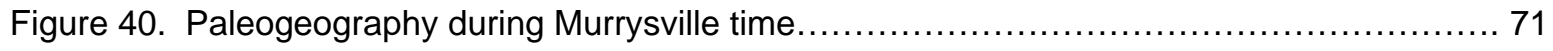

Figure 41 . Sea-level curve during the Late Frasnian-Early Tournaisian........................ 73

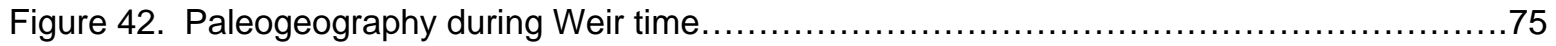




\section{Introduction - Purpose of Study}

With the ever-increasing energy demand for oil and natural gas, high petroleum prices have revitalized drilling and exploration in the Appalachian Basin. Southwestern Pennsylvania has received a significant development boost during these times of high prices as companies look for inexpensive drilling opportunities in Upper Devonian-Lower Mississippian reservoirs. Despite having its oil and gas roots back to 1859 with Drake's well in Titusville, PA, the oil and gas fields of Pennsylvania have been under nearly constant development up to the present, making the Appalachian Basin perhaps the most mature producing basin in the world.

Despite the sheer number of wells drilled into shallow Upper Devonian-Lower Mississippian reservoirs; there is still a great number of regional stratigraphic relationships that are not adequately understood. Part of the difficulty stems from the fact that the majority of subsurface information is in the hands of oil and gas companies that are somewhat reluctant to distribute these data to outside sources. Proprietary information is a valuable asset to any company in the oil and gas sector. Second, the data that companies do have are sometimes incomplete or limited in area, and this fact necessitates that geologic mapping must be confined to limited areas where well logs and field information are available. Third, in the era of quick turn-around on project development, it is often difficult to present regional work due to the limited time involved in research and data gathering. Mapping on small scales (fields) is the order of the day. Lastly, southwestern Pennsylvania is generally "outcrop poor" when it comes to the Upper Devonian-Lower Mississippian stratigraphic section. The overwhelming majority of subsurface data comes from well logs, and it is a difficult task to translate these data and compare it to the physical reality of the outcrop. Regional work is often the key to unlocking why a reservoir is productive in some areas and not others, and to give exploration companies a framework for prospecting in areas that have little development.

The purpose of this research is to re-examine, from a regional perspective, selected Upper Devonian and Lower Mississippian stratigraphic units, namely, the Hundred Foot, Murrysville and Weir sandstones in southwestern Pennsylvania (Figure 1.). There are very little published data that adequately present isopach maps for these units in Pennsylvania; therefore, the primary goal of the study is to generate maps of sandstone distribution and thickness. There are also a number of excellent stratigraphic cross-sections by previous authors for southwestern Pennsylvania, and the 


\begin{tabular}{|c|c|c|}
\hline Age & Formation & $\begin{array}{c}\text { Drillers' Nomenclature } \\
\text { (Sandstones) }\end{array}$ \\
\hline \multirow{3}{*}{$\begin{array}{l}\text { Lower } \\
\text { Mississippian }\end{array}$} & Burgoon Fm. & Big Injun \\
\hline & Shenango Fm. & Squaw \\
\hline & Cuyahoga Fm. & $2^{\text {nd }}$ Gas, Weir \\
\hline \multirow{4}{*}{$\begin{array}{l}\text { Upper } \\
\text { Devonian }\end{array}$} & (unnamed) & $\left.\begin{array}{r}\text { Berea } \\
\text { Cussewago }\end{array}\right\}$ Murrysville \\
\hline & Riceville Fm. & \\
\hline & Venango Fm. & $\left.\begin{array}{r}\text { Gantz } \\
\text { Fifty Foot }\end{array}\right\}$ Hundred Foot \\
\hline & & $\begin{array}{l}30 \text { Foot, Upper Nineveh } \\
\text { Snee, Lower Nineveh } \\
\text { Gordon Stray } \\
\text { Gordon }\end{array}$ \\
\hline
\end{tabular}

Figure 1. Generally accepted stratigraphic formation names and drillers' nomenclature used in southwestern Pennsylvania. Highlighted sandstones are those discussed in this study. 
second aim of this research is to extend these previous cross-sections farther east to their respective outcrops.

After researching and generating the isopach maps and cross sections, a number of interesting depositional features became evident that could only be seen when viewing the stratigraphy from a regional perspective. This paper attempts to show that two different types of structural features may have influenced depositional patterns within the developing foreland basin: Rome Trough basement faults and cross-structural lineaments. Both may have acted as sediment traps, or conversely, as sediment pathways during deposition. The final piece of research is to present a general paleogeographic interpretation for the Hundred Foot, Murrysville, and Weir sandstones and mechanisms for their apparent distribution. 


\section{Previous Studies}

The earliest work on Upper Devonian-Lower Mississippian stratigraphy was purely descriptive in nature with Newberry (1870) naming the Berea grit from exposures at Berea, Ohio. It was some years later, when oil and gas exploration became more prevalent, that Butts and Leverett (1904) coined the name Murrysville for the first prolific gas wells drilled near Murrysville, Pennsylvania. The term Murrysville has long been thought to represent the eastern equivalent of the western Ohio Berea and is generally the most common term in the literature, although various other names, especially drillers' terms (Butler County, Butler First, Butler Gas, Butler 30-Foot, Great Salt Water) have been used (Hughes, 1933.) The Cussewago was first named from Whites' (1881) type locality along Cussewago Creek in Crawford Co., PA, and has been interpreted as the Murrysville equivalent in northwestern Pennsylvania.

The first comprehensive correlation and description of the Berea in Ohio and Pennsylvania came from Pepper et al. (1954) who cleared up much of the correlation confusion, and confirmed that the type Berea of Ohio was equivalent to the drillers' Berea (Murrysville) in Western Pennsylvania, inasmuch as they both fell within the same stratigraphic sequence. Pepper et al (1954) further suggested that the Berea in Ohio had a northwestern source while the equivalent Murrysville in Pennsylvania had a southeastern source. Despite their seminal research and correlations, there was still some lingering confusion as to how the Murrysville and Berea were related.

More recent work, especially by Harper and Laughrey (1987) and Harper et al. (1989), has shown that in portions of Allegheny County, PA, and westward, the thick Murrysville sand splits into two sands, separated by the Bedford Shale (Figure 2.) They suggest that the Cussewago is equivalent only to the lower portion of the Murrysville and the Berea is equivalent to the upper portion. East of Allegheny County the Murrysville constitutes a single thick sandstone, with some exceptions (de Witt, 1946; Tomastik, 1996.) This thicker sequence is the focal point of this paper. Later work by Pashin and Ettensohn (1995) came to similar conclusions: that the Berea in Ohio lies above the Bedford Shale, whereas the Murrysville or Second Berea (Cussewago) lies below the Bedford Shale in western Pennsylvania.

Some authors have suggested renaming the Murrysville to the more descriptive Cussewago (Pepper et al., 1954; Kammer and Bjerstedt, 1986) to avoid further confusion. However, depositional 


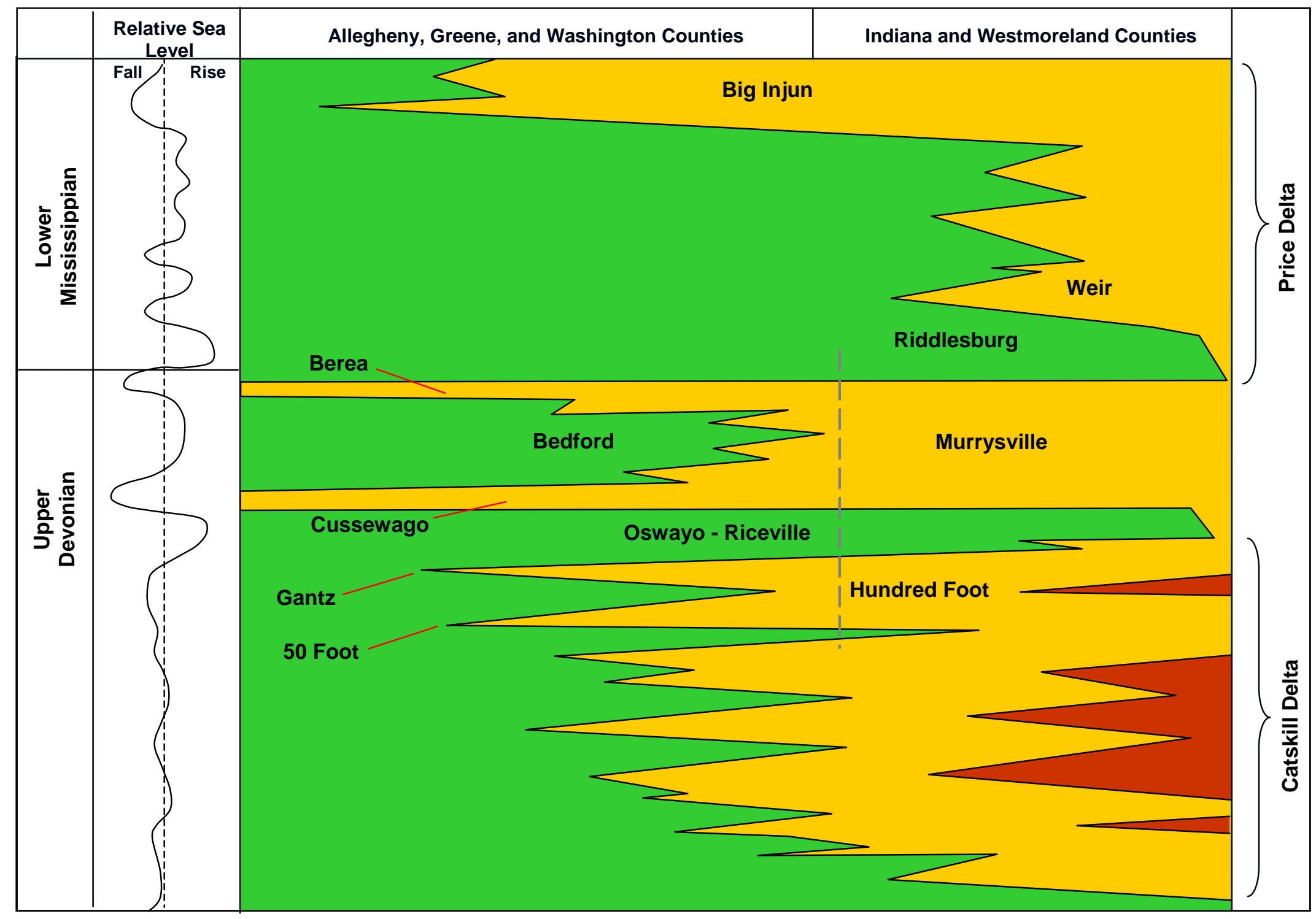

Figure 2. Stratigraphic relationships and relative sea-level change within selected counties in southwestern Pennsylvania. The gray dashed line indicates the approximate area where a change in drillers' nomenclature exists for the Murrysville and Hundred Foot in the east and their western equivalents. (Adapted and modified from Harper and Laughrey, 1987.) 
interpretations from Pennsylvania suggest a fluvial environment for the Murrysville, whereas equivalent sandstones in West Virginia suggest marine deposition (Kammer and Bjerstedt, 1986; Dolezal, 2004.) Bjerstedt and Kammer (1988) described the Cussewago as a shoreface sandstone generated during a transgressive phase of basin development. Harper and Laughrey (1989) and this study hold a rather opposite view as the Murrysville outcrop at Cramer, PA, and the depositional geometry of the mapped isopach body suggest fluvial-deltaic deposition. Additional work is needed to define how the Cussewago of West Virginia relates to the Cussewago / Lower Murrysville of Pennsylvania. The most comprehensive descriptions of Murrysville equivalent sandstones in adjacent states have been detailed by Dennison (1970); Boswell (1985); and Boswell et al. (1996) in West Virginia, and by Pepper et al. (1954); Potter et al. (1983); and Pashin and Ettensohn (1995) in Ohio.

Surprisingly, since the first regional correlations were conducted, the placement of the Devonian-Mississippian boundary has moved "up and down through about $300 \mathrm{ft}$. of section in western Pennsylvania" (Harper et al., 1989.) De Witt (1970) had suggested that the Berea is Lower Mississippian; whereas paleontological evidence from various authors (Carter and Kammer, 1990; Feldman et al., 1992) places the Berea in the Upper Devonian. Recent reevaluation of paleontological data (Pashin and Ettensohn, 1995) has placed the Berea and its equivalents in the Upper Devonian, and will be the accepted line of thought in this paper.

Stratigraphically older than the Murrysville are the sandstones, shales, and siltstones of the Venango Formation. The Hundred Foot sandstone, the lowermost unit in this study, the superjacent Riceville Shale, and the shale and siltstone of the Upper Venango were originally described by Stevenson (1878), who regarded this sequence as a transition zone between the Catskill Delta Complex below and the Pocono (or Price) Delta Complex above (Figure 2 and 3.) Various authors, namely Butts (1908) and Phalen (1910), were at odds as to which delta complex these rocks should belong. Laird (1941) attempted to rectify this conflict and placed the Upper Venango strata into separate units, a lower shale unit and an upper sandstone unit. Fettke and Bayles (1945) and Bayles (1949) referred to the uppermost shale beds in the upper sandstone unit, the Riceville, as equivalent to the Oswayo in New York. Harper and Laughrey (1987) felt that using the term Oswayo in Pennsylvania in anything but an informal sense is unjustified, citing that although there are lithologic similarities as well as similar fossil assemblages between the Oswayo Formation and the Upper Venango (Riceville), 


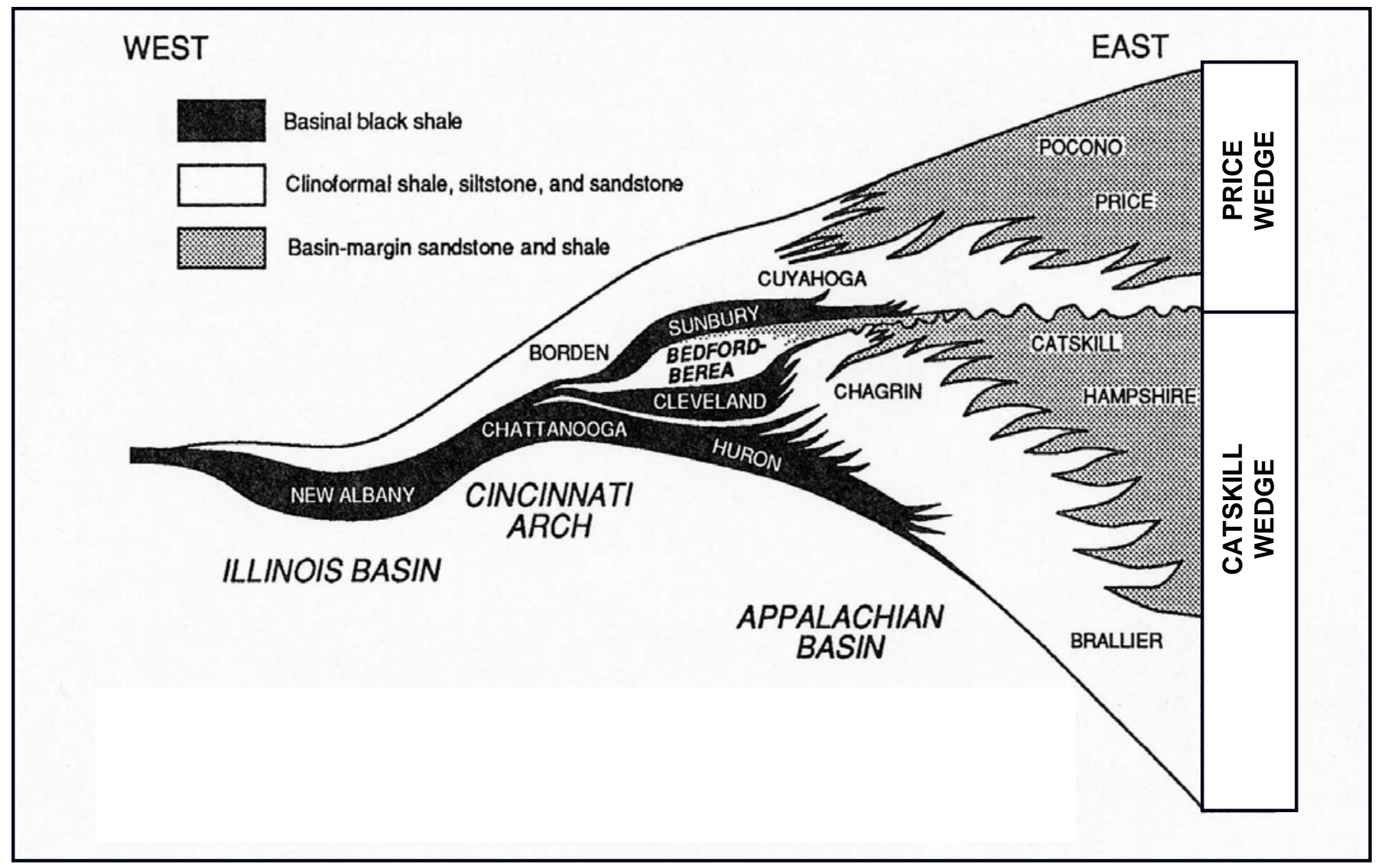

Figure 3. Regional stratigraphic relationships of the Berea (Murrysville) and adjacent formations. The Berea as shown here is a wedge of sediments extending further west than Catskill deposition and is considered a separate event preceding Price deposition. The Catskill delta was basin filling throughout the Upper Devonian until a major regression shifted the paleoshore to the west, allowing progradation of the Berea/Murrysville beyond the Catskill wedge (from Pashin and Ettensohn, 1995.) 
the Oswayo type section in New York is thought to be entirely marine whereas the Upper Venango in Pennsylvania displays both marine and nonmarine sedimentation. Recent work by Boswell et al (1987), and Bjerstedt and Kammer (1988) argue that the Riceville is the deeper marine equivalent of the more nearshore Oswayo. Additional work is needed to fully evaluate the interrelationships among the Venango Group sediments in Pennsylvania and their equivalents (Oswayo) in surrounding states.

Stratigraphically younger than the Murrysville are the Lower Mississippian Riddlesburg Shale and the Weir sandstone. Originally named by Reger (1927) for the outcrop of a green to black shale near the town of Riddlesburg, Pennsylvania, the Riddlesburg Shale is a member of the Rockwell Formation and is marine in origin as evidenced from its marine fauna. The Weir sandstone, the uppermost unit in this study, was described by Laird (1941) who called it the Conglomerate I for its massive conglomerate appearance in outcrop. Keep in mind that very little published work exists on the Weir sandstone in Pennsylvania. The Weir sandstone is actually a drillers' term originally applied to sandstones that occur in West Virginia. Some lines of thought put the drillers' $2^{\text {nd }}$ Gas sandstone (Weir) of Pennsylvania as the correlative formation to the Weir sandstone in West Virginia (Matchen, 2003, personal communication.) There is a lack of data to support that the Weir sandstones in Pennsylvania and West Virginia are equivalents inasmuch as they do occupy the same approximate stratigraphic position. However, the Weir as used in this study is widespread and consistent enough to be distinguished as a separate unit. 


\section{Stratigraphy of Southwestern Pennsylvania}

One of the major hurdles in undertaking a study of this type is the inconsistency in the naming of lithologic units on a regional basis. Early oil and gas drilling in the Appalachian basin was undertaken by small, independent groups with little regard to the naming conventions of stratigraphic sequences. The result is that local names were given to specific "drillers' sands" resulting in different names for the same formation. The problem was further complicated when workers from one area would move into a new region and apply the old, familiar names to stratigraphic units within that area. The resulting sequences are a mix of drillers' terms that may or may not be representative of actual correlative formations (Pepper et al., 1954.) Figure 1 is the generally accepted drillers' nomenclature used in western Pennsylvania.

The Devonian / Mississippian lithologic sequence in southwestern Pennsylvania constitutes late Famennian and early Tournaisian age sediments that were shed westward from eastern highlands uplifted during the Acadian orogeny. Stratigraphically, the uppermost Upper Devonian, and Lower Mississippian units will be examined in detail, including those formations which are stratigraphically above the drillers' Gordon sandstone (upper Venango Formation) and upward in section to the Weir sandstone. The total thickness for this sediment package averages approximately $700 \mathrm{ft}(200 \mathrm{~m})$, but varies greatly throughout the study area. Figure 3 is a stylized section for the southwestern portion of Pennsylvania for this study, based on observations by Pashin and Ettensohn (1995.)

The youngest lithologic unit within the study area is the Weir sandstone which is a member of the Rockwell Formation (Figure 2.) Below the Weir sandstone is the Riddlesburg Shale, a Sunbury Shale equivalent that sits disconformably above the Murrysville / Berea Sandstone. Below the Berea, especially in portions of Allegheny, Greene, and Washington Counties, are the interbedded siltstones and shales that comprise the Bedford Shale. Below the Bedford Shale is the Cussewago Sandstone. In the focus area of this paper, east of the counties mentioned above, the Bedford Shale pinches out and the Berea and the Cussewago merge to form the Murrysville, a single massive sandstone. Below the Murrysville is the Riceville Shale that is equivalent to the Oswayo Shale in West Virginia and the Chagrin Shale in Ohio. Below the Riceville is the first of the Venango Formation sandstones in southwestern Pennsylvania, the Hundred Foot sandstone. Note that the Hundred Foot is actually a

drillers' term rather than a formal type name however, the sandstone is widespread enough to justify 
the continued use of this name, at least in southwestern Pennsylvania. The drillers' terms Gantz and Fifty Foot, which are also commonly used in southwestern Pennsylvania and northern West Virginia, represent the splitting of the Hundred Foot sandstone into an upper and lower zone, much like the Berea and Cussewago are upper and lower zones of the Murrysville.

The Hundred Foot, Gantz and Fifty Foot sandstones are dominantly fine to coarse, angular to subangular, quartzitic sandstone and conglomerate that are white to gray in color. Interbedded siltstone and shale are common throughout much of the Hundred Foot within the study area. All of the sandstones mentioned above are thought to be migrating barrier-bar sandstones. The Riceville Shale consists mostly of white, light-gray and tan, fossiliferous siltstone and gray silty-shale and mudstone, and rests conformably above the Hundred Foot Sand. The Riceville represents deeper-marine sediments deposited just prior to the westward progradation of the Murrysville (Laird, 1941, Pepper et al., 1954; Potter et al., 1983; Harper and Laughrey, 1989; Pashin and Ettensohn, 1995.)

The Murrysville is generally dull greenish-yellow to gray sandstone and may contain conglomeratic lenses with pebbles greater than $5 \mathrm{~mm}$ in diameter. This unit also contains interbedded siltstone and shale. The Murrysville is thought to represent a fluvial environment that transported sediments westward into a shallow restricted sea that covered much of Ohio, western Pennsylvania and West Virginia during the late Devonian (Harper et al., 1989; Harper and Laughrey, 1987.) Although the Berea is well documented in Ohio, correlations often become difficult when trying to tie similar sandstones in southwestern Pennsylvania. Early research of Berea deposition, especially that of Pepper et al. (1954) proposed the idea that there were two different source areas for deposition during the Early Mississippian, one dispersing sediments in a southerly direction throughout mid-Ohio (the type Berea), and another source moving sediments westward into southwestern Pennsylvania (Murrysville) (Figure 4.)

The Riddlesburg Shale that rests disconformably above the Murrysville contains dark gray to greenish and grayish black laminated shale and siltstone with occasional sandstone and limestone beds. Harper et al. (1989) have interpreted the Riddlesburg as restricted marine because it contains burrows, brachiopods, bivalves, and occasional plant debris. It also marks a major transgressive event above the Murrysville. The Riddlesburg Shale grades upward into the Weir sandstone, a coarseningupward succession of fine-to coarse-grained sandstone and conglomerate. The Weir may represent 


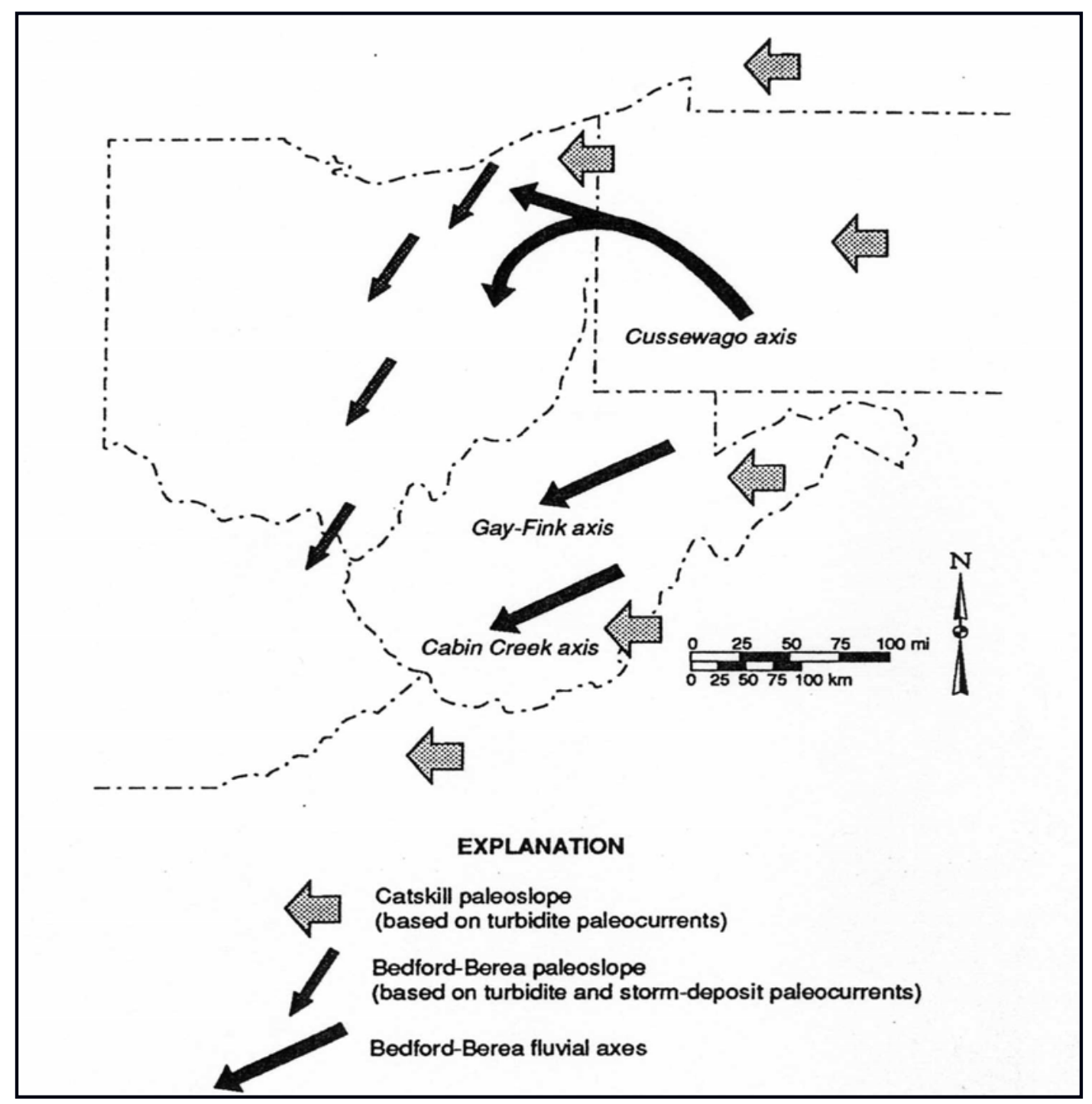

Figure 4. Interpreted sediment dispersal pathways of Berea during the Late Devonian. The Ohio Berea displays a southwesterly trend while the Pennsylvania Cussewago (Murrysville) trends to the northwest. Observations from this study also suggest a west-northwesterly trend for the Murrysville (from Pashin and Ettensohn, 1995.) 
shoreface and coastal deposition along a fluvial-dominated shoreline (Harper et al., 1989.) The Weir has also been referred to as the $2^{\text {nd }}$ Gas sandstone, another informal drillers' term. Although beyond the scope of this paper, one additional thought needs consideration concerning the Weir sandstone. There is a second sandstone that occurs in Allegheny, Washington, and Greene Counties above the Riddlesburg Shale called the Squaw (and occasionally the Papoose) sand that may somehow be related to the Weir sandstone further east, although the exact relationship remains undefined.

Late Devonian and Early Mississippian sediment deposition involved a complex interaction between eustatic changes (Van Tassel, 1994) and tectonic controls, especially during the development of the Acadian foreland basin (Fiall, 1985; Ettensohn, 1994; Pashin and Ettensohn, 1995.) In general, Upper Devonian-Lower Mississippian sandstone depositional systems within the study area can be characterized as barrier bar, shoreface, and fluvial deposits that accumulated on the eastern margin of a shallow, foreland basin (Cant, 1982; Dennison, 1985) and underwent intermittent periods of regressive and transgressive sea-level fluctuations. Isaacson et al. (1999) suggested that Famennian glaciation created a global sea-level drop, and may have generated a forced-regression within the Acadian epiric seaway. Pashin and Ettensohn (1995) also proposed a forced-regression scenario from their work on the Berea in Ohio. 


\section{Structural History of Southwestern Pennsylvania}

The study area in southwestern Pennsylvania falls within the Appalachian Plateau Province, and is dominated by high- and low-amplitude folds created during the Appalachian orogeny in the Pennsylvanian Period. The Appalachian Plateau province is characterized by broad, gentle, northeastsouthwest trending folds that, in general, are arcuate and parallel to the Valley and Ridge province. Wavelengths for folds in this region can range from 5 to 20 miles (8 to $32 \mathrm{~km}$ ) (Figure 5), with structural relief from hundreds of feet to over 2,500 feet $(4,000 \mathrm{~m})$ (Beardsley et al, 1999.) These structural folds created the necessary hydrocarbon trapping mechanism that would later be exploited during the early years of the petroleum industry. Despite the dominating structural style of Alleghenian deformation, there are a series of other recognizable deformation events that played a key role in Upper DevonianLower Mississippian sediment deposition.

The first is the development of the Rome Trough during the Precambrian. This deep structural feature, trending northeast-southwest, can be traced from New York, Pennsylvania, West Virginia, and into Kentucky (Figure 6.) The trough is a remnant of an ancient Cambrian rifting event that created a series of down-to-the-east basement faults that would later lead to the development of a foreland basin in this region (Wagner, 1976.) These normal faults may have been reactivated through time either by dropping down or popping up in response to regional tectonic events. Movement has been suggested along this fault system during the Cambrian and Ordovician and throughout most of the Paleozoic. This paper suggests that sediments as late as the Devonian-Mississippian may have been influenced by these ancient basement faults. Boswell (1985) has described similar Acadian clastic wedge sediments in West Virginia that show stacking patterns above Rome Trough basement faults.

Another feature of the Rome Trough that may have played a role in Devonian sedimentation was the creation of cross-structural features (lineaments) that are normal to the Rome Trough graben faults. Wagner and Lytle (1976) were the first to suggest that these features (also called cross-strike structural discontinuities or CSDs) had some influence on existing oil-field production in western Pennsylvania. In general, these features trend northwest-southeast and are thought to represent tensional fractures generated during the opening and closing of the rift basin during the Paleozoic. These CSDs had the potential to be reactivated during the Devonian Acadian orogeny. Figure 7 shows the inferred positions of the major lineaments in Pennsylvania and their orientation to one another. 


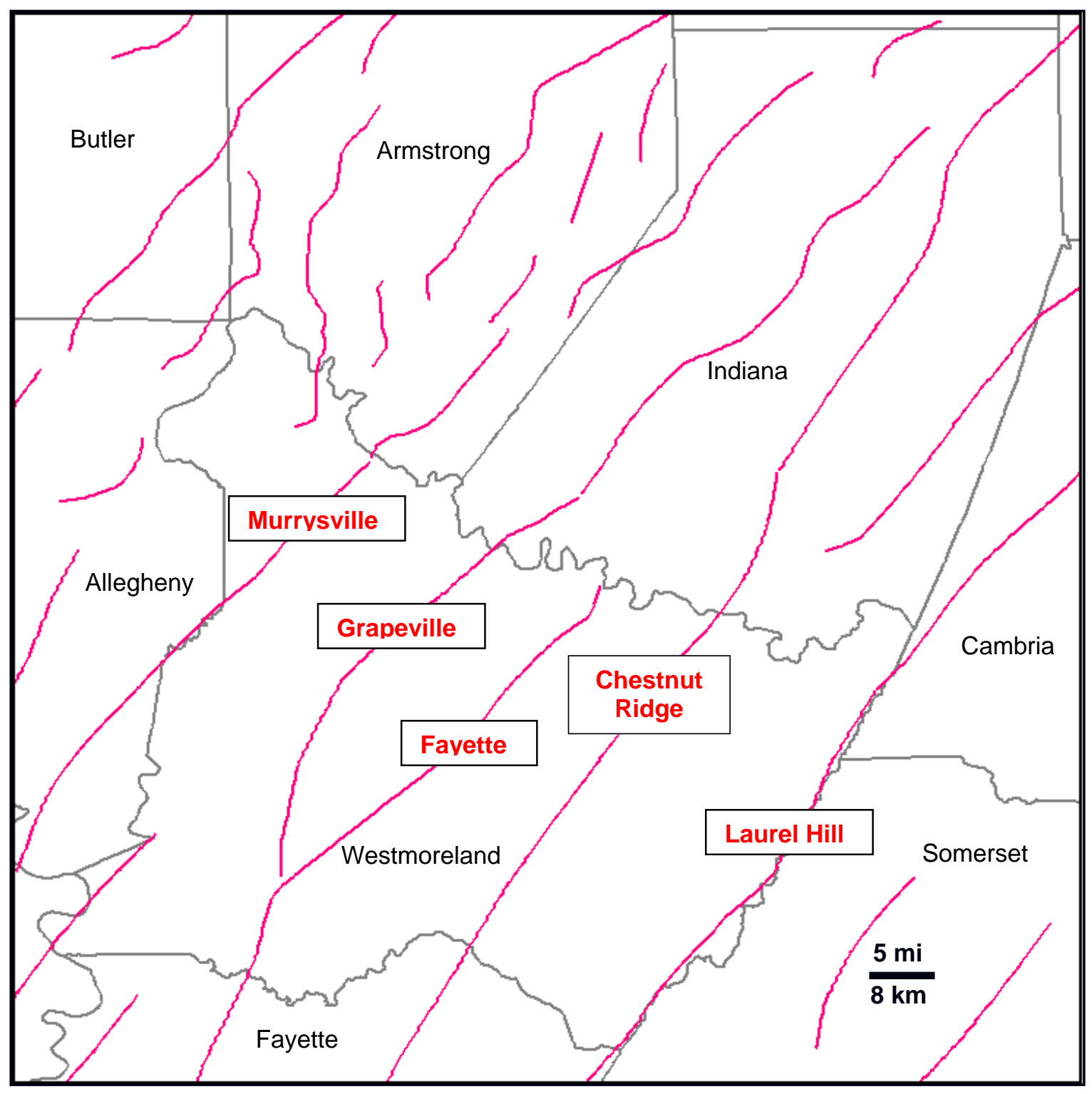

Figure 5. Orientations of major anticlinal axes within the study area. Dominant trend is northeastsouthwest. Note the bifurcation of the Grapeville and Fayette anticlines, and the terminations associated with many of the axial traces. These features were likely caused by cross-structural discontinuities that created varying degrees of detachments and folding during the Alleghenian orogeny. 


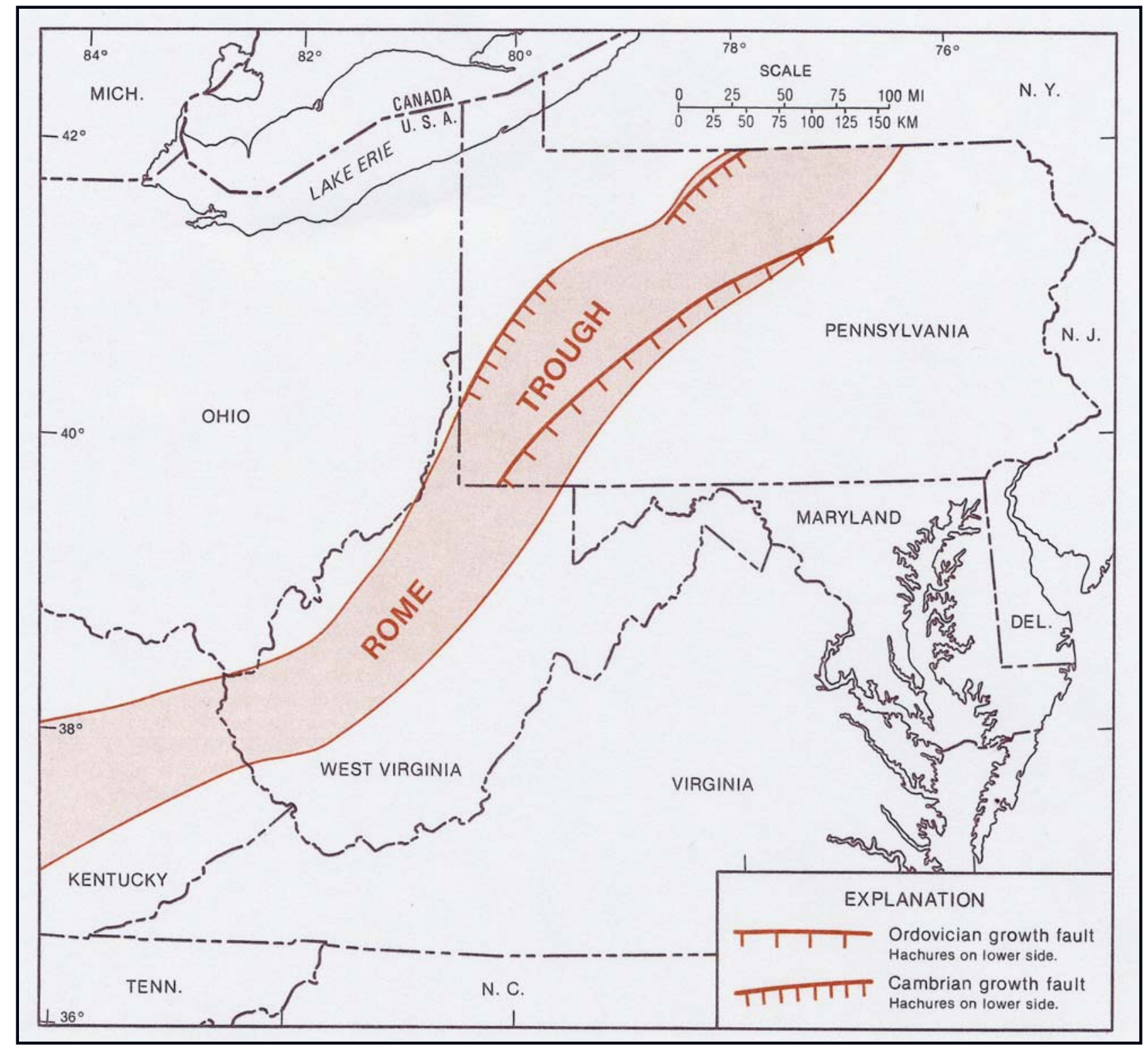

Figure 6. Positioning of the Rome Trough within the Appalachian Basin. Previous work suggests faulting occurred from the Precambrian to the Ordovician and may have influenced sediment deposition into the Late Devonian and Early Mississippian when these pre-existing features were reactivated during the Acadian orogeny (from Beardsley et al., 1999; faults from Wagner, 1971.) 


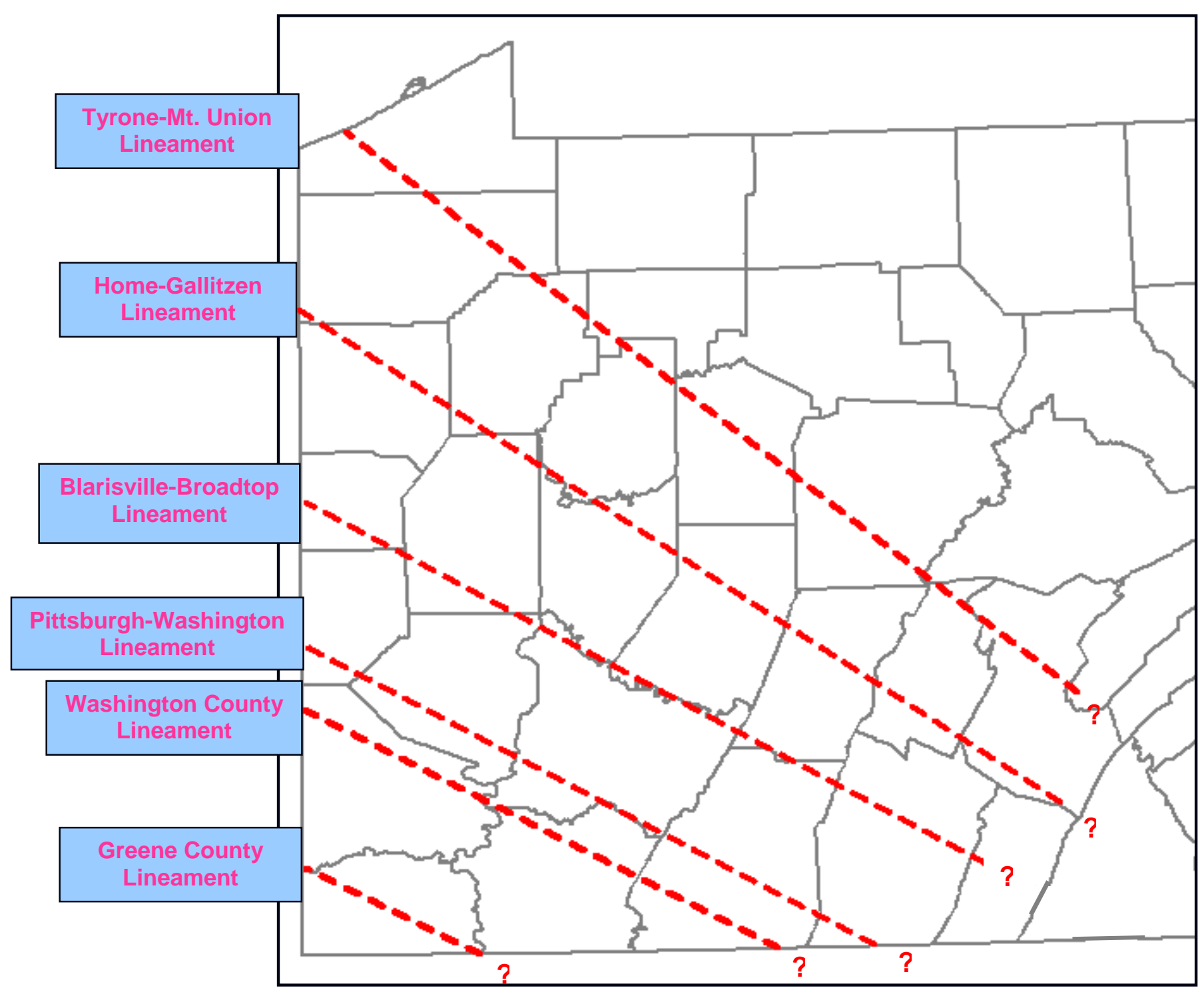

Figure 7. Orientation of major lineaments in western Pennsylvania. The dominant trend is northwestsoutheast (adapted from Flaherty, 1996, and Gold et al, 2005.) 
The two most pronounced of these lineaments are the Tyrone-Mt. Union (Rogers and Anderson, 1984) and the Pittsburgh-Washington Lineaments (Lavin et al., 1982.) The Pittsburgh-Washington Lineament has also been called the $40^{\text {th }}$ Parallel Lineament by various authors (Root and Hoskins, 1977; Gao, 2000; Castle, 2001.) Research suggests that these two lineaments may mark the boundaries of major crustal blocks that existed as part of an ancient transform fault system. There are also smaller, less pronounced lineaments in western Pennsylvania that have been inferred from gravity surveys, namely the Home-Gallitzen, Blairsville-Broadtop, Washington County, and Greene County Lineaments (Roen, 1968; Parrish and Lavin, 1982; Gold et al., 2005.) Keep in mind that lineaments do not exist as a single plane in the subsurface, but rather exhibit an area of damage surrounding the dominant zone of weakness. For the sake of simplicity, the lineaments in Figure 7 are shown as straight lines that, most likely, have subtle orientation changes along the transform zone.

Whereas lineaments have not been directly observed, various lines of evidence point to their existence in western Pennsylvania: (1) Bouguer gravity and magnetic anomalies show marked changes in response on opposing sides of a lineament (Parrish, 1981); (2) abrupt terminations in sediment deposition and facies changes have been known to occur near a proposed lineament (the Devonian Tully Limestone and Oriskany Sandstone, for instance); (3) sediment movement and channeling has been known to occur along a proposed lineament, especially in Catskill delta sediments (the Kane sandstone; Hussing, 1994); (4) pre-existing fractures may have allowed kimberlite emplacement in southwestern Pennsylvania during the Jurassic (Parrish and Lavin, 1982); (5) abrupt terminations can be seen in Alleghenian folds as they plunge out or in some instances bifurcate (Figure 8); (6) modern river drainage patterns may show angled bends over portions of their course especially where river and streams have breached existing folds (the Conemaugh River, for example.) Figure 9 displays some hypothetical methods of lineament development, and potential diagnostic features that may be evident from subsurface data.

Two other orogenic events also impacted the structural framework in the Appalachian Basin. The first was the Taconic orogeny, which occurred in the Ordovician, and the second, and most important to this study, is the Acadian orogeny, that occurred in the Late Devonian. Figure 10 is a continental reconstruction during the Late Devonian. The Acadian event marked the collision of the 


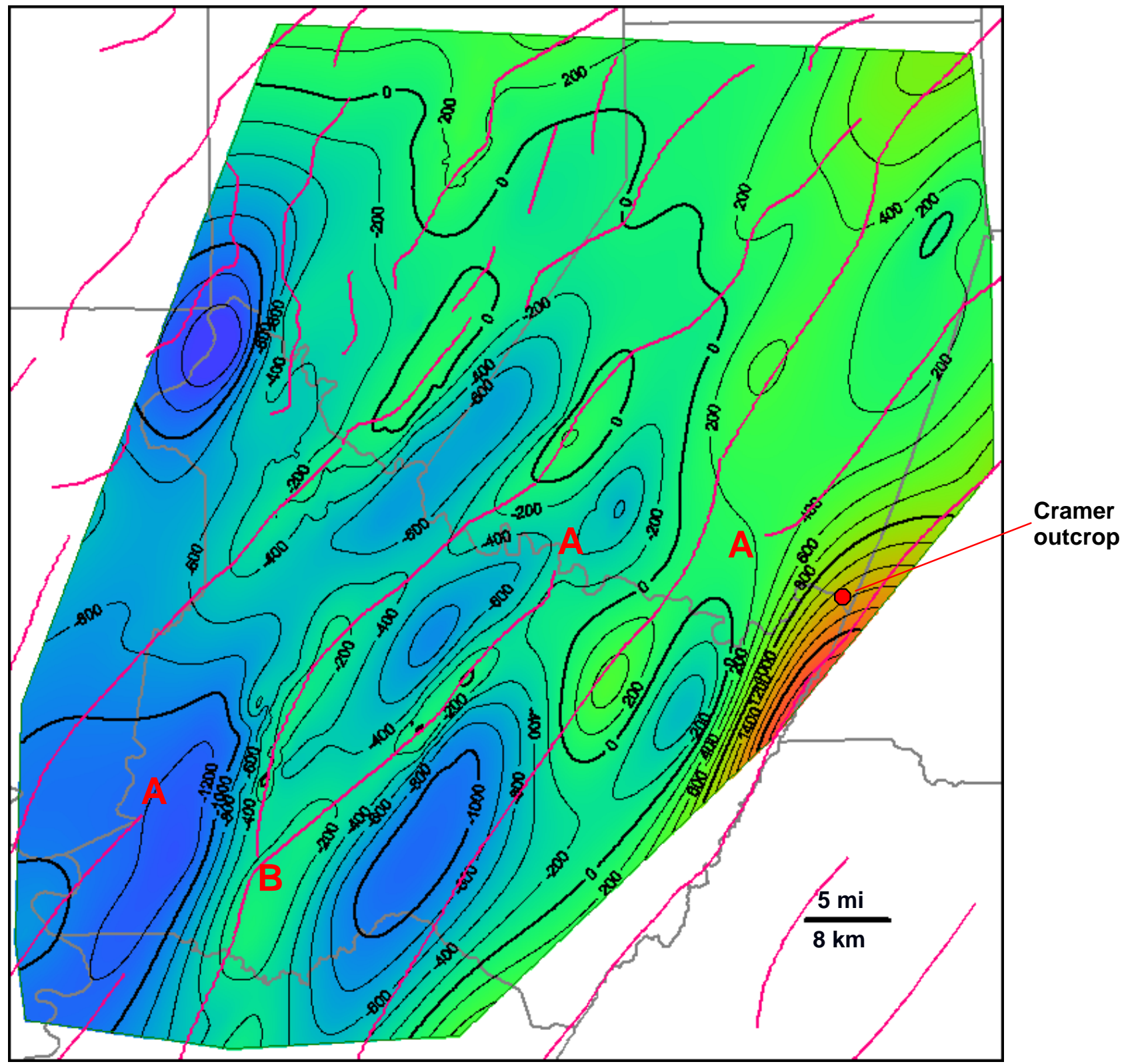

Figure 8. Subsea structure map at the top of the Murrysville. Terminations (A) and bifurcation (B) of anticlines created during the Alleghenian orogeny may have been controlled by lineaments. Cool colors represent structural lows and warm colors are structural highs. The contour interval is $200 \mathrm{ft}$ (61 m.) 


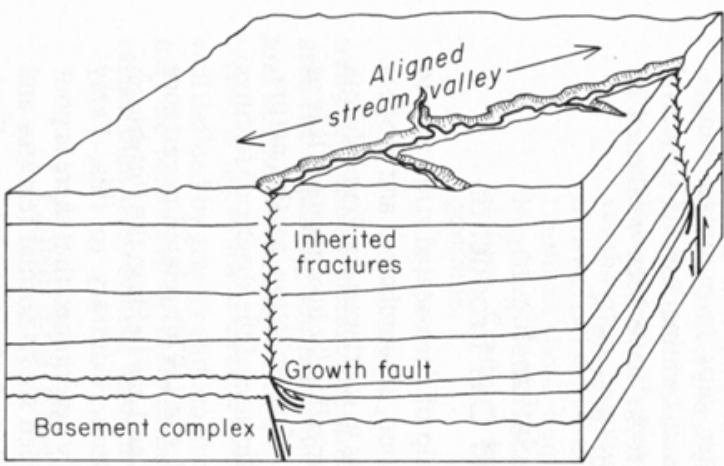

A

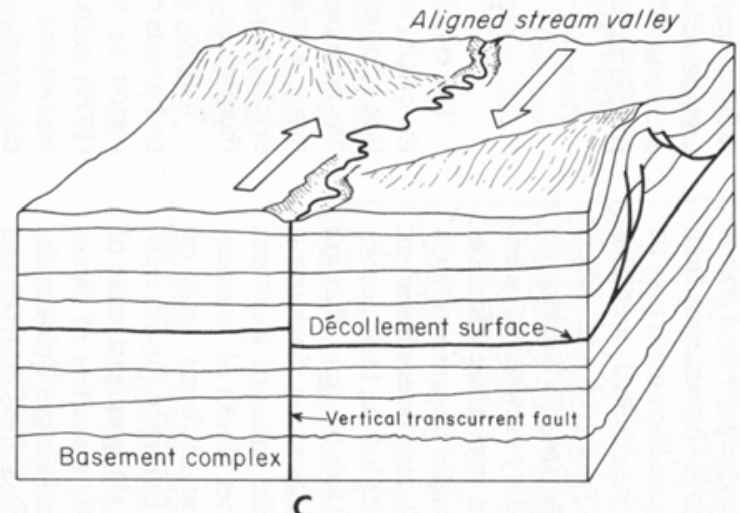

C

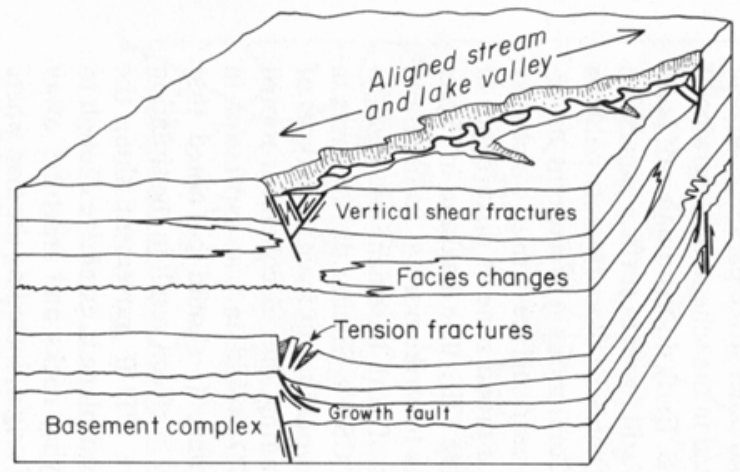

B

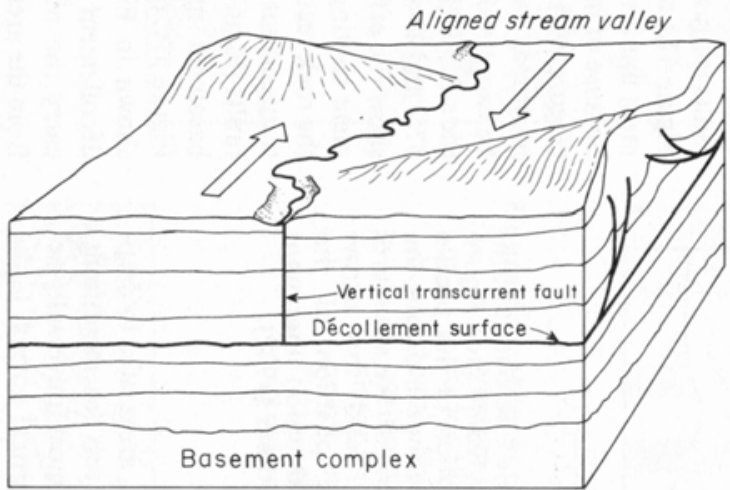

D

Figure 57. Block diagrams of four hypothetical situations in which deep-seated tectonic movements affected surface physiography and subsurface structure and stratigraphy. Concepts modified from Meissner (1984) and Kowalik and Gold (1976).

A. Vertical basement faulting, movement discontinued early, resulting in an inherited fracture pattern developed in successive strata.

B. Vertical basement faulting, movement continuous or recurrent, resulting in warping, tension fracturing, and/or shear fracturing at intermittent intervals. Such features in turn may affect depositional patterns.

C. Transcurrent basement faulting, movement recurrent, resulting in the offset of structural features and the change of stratigraphic position of décollement surfaces and other thrust faults.

D. Transcurrent faulting rooted in a deep décollement thrust zone, movement recurrent. Structural plunge of the anticlines may be offset in C and D because the rock units in adjacent blocks respond differently to compressional forces.

Figure 9. Four methods of generating lineaments and their diagnostic features (from Harper and Laughrey, 1987.) 


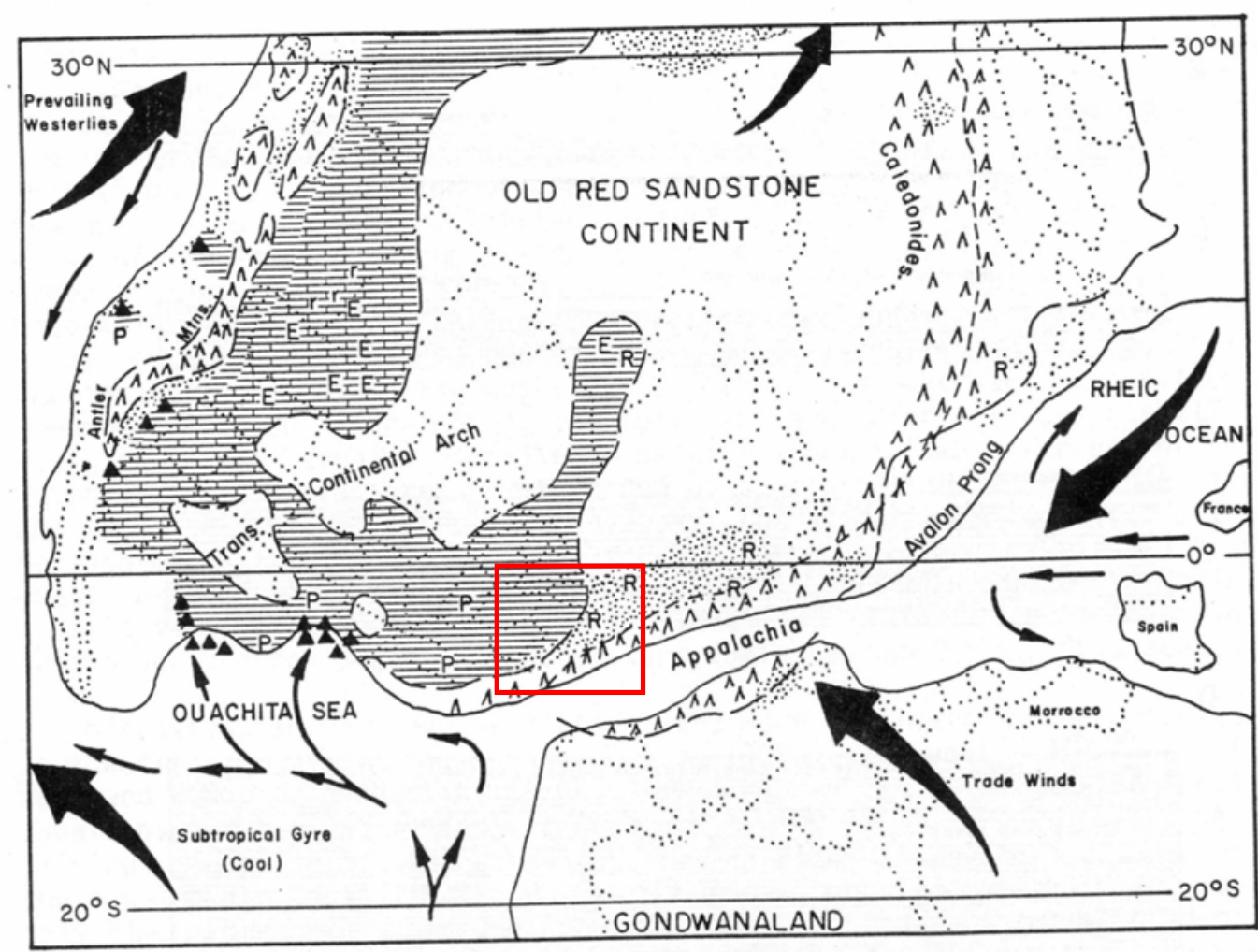

LEGEND
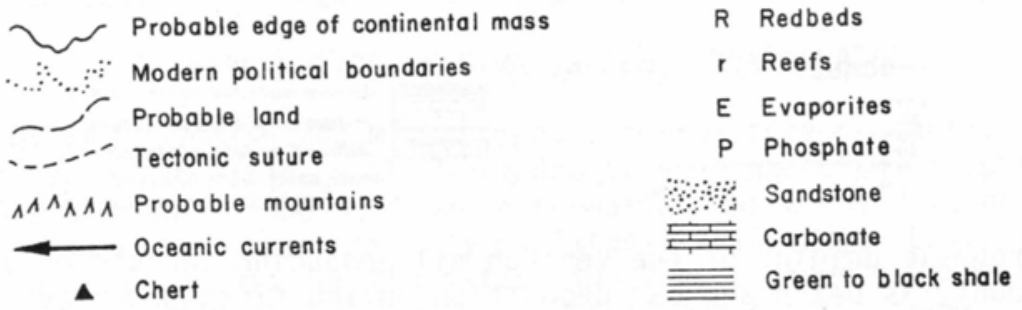

Figure 10. Reconstruction of continent positions during the Late Devonian. Red box highlights areas in New York, Pennsylvania, and West Virginia (from Sevon and Woodrow, 1981.) 
microcontinent Avalonia with eastern North American and generally occurred from Nova Scotia into New York (Ettensohn, 1985.) It is also likely that deformation continued farther south into what would be Pennsylvania, West Virginia and Virginia (Figure 11). This collision created the necessary uplift to begin shedding clastic material from eastern highlands into the developing foreland basin. The Catskill Delta Complex (of which the Hundred Foot Sand is a member) was created in this manner. As a consequence of the collision, the existing Rome Trough faults and associated lineaments may have been reactivated and continued to be active throughout the Late Devonian and Early Mississippian. The argument will be made here that the Murrysville as well as the Hundred Foot and Weir sandstones display features that suggest tectonic controls during deposition. 


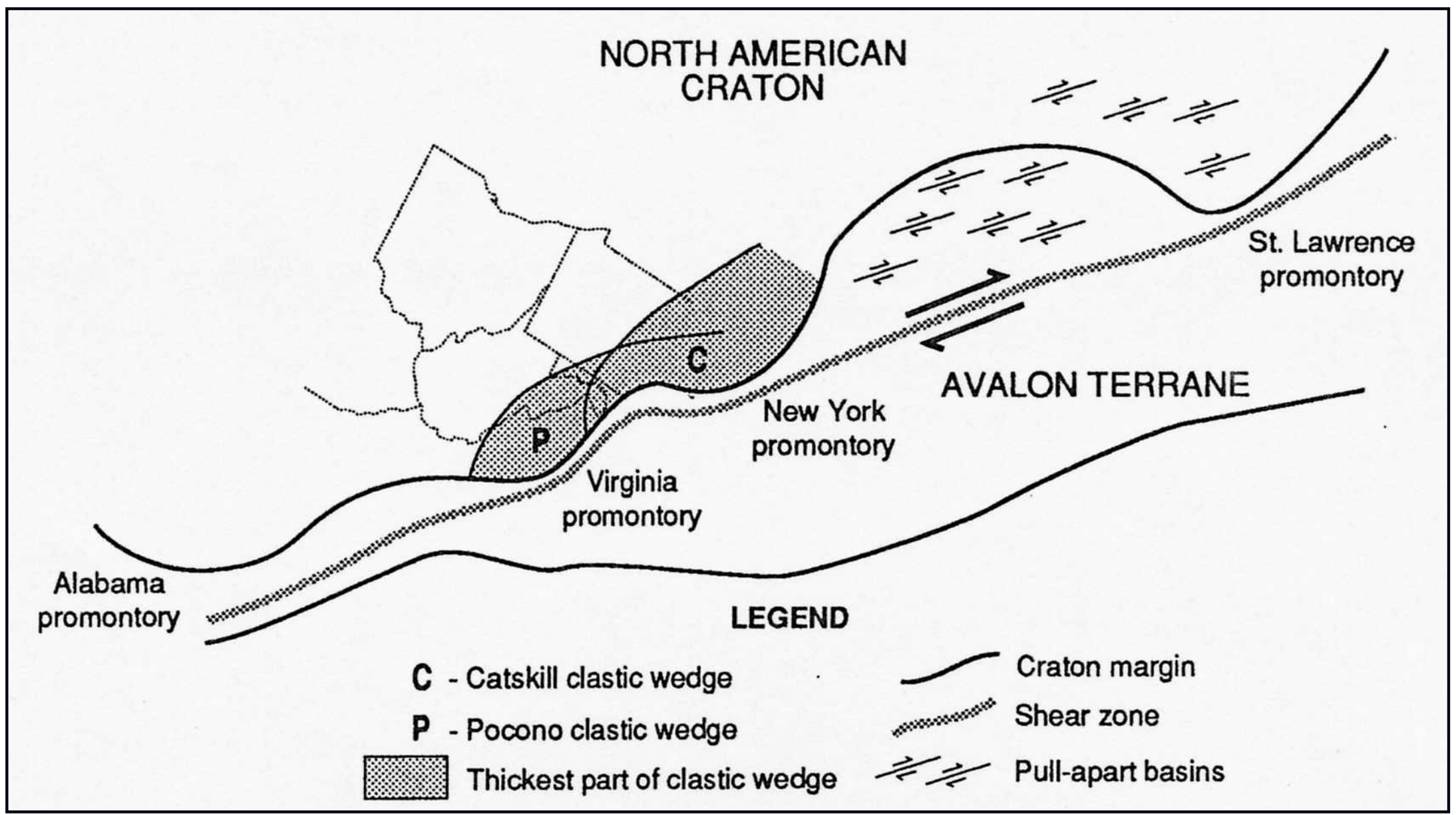

Figure 11. Tectonic setting showing the collisions that led to the formation of the Catskill wedge and the Price wedge (the older Pocono name is used in the illustration.) The Murrysville sandstone would be deposited between these two basin filling pulses (from Ettensohn, 1985.) 


\section{Area of Investigation}

The focus area for this study (Figure 12) encompasses all or portions of seven counties in southwestern Pennsylvania: Allegheny, Armstrong, Cambria, Fayette, Indiana, Washington, and Westmoreland counties, all of which fall within the Appalachian Plateau province. The geographic extents for mapping purposes range from latitude $N 40.9175$ to $S 40.0079$ and longitude E 78.8151 to $W$ 79.9334. The extent of the generated isopach maps cover approximately 2,650 square miles ( $4,270 \mathrm{sq}-\mathrm{km}$.)

This area was chosen for a number of reasons, namely: (1) the existence of gas storage fields in the Murrysville at the center of the study area (Westmoreland County) allows for a welldocumented Murrysville type section to be extended into areas that have not previously been described and correlated in detail; (2) there is better well-log coverage and availability here than in other areas; (3) the only well-documented outcrop of the Hundred Foot, Murrysville and Weir sandstones occur near the town of Cramer, PA, and it was essential to include these data in the study; (4) this area also exhibits two structural features that may have influenced sediment deposition during this interval. The first feature is the eastern edge of the Rome Trough that projects southwest-northeast through western Pennsylvania, and essentially bisects Westmoreland County (Figure 13, from Schultz, 1999), and the second is the inferred existence of cross-structural discontinuities (lineaments) that cross-cut the dominant northeast-southwest trending structural features (Figure 14); (5) this section compliments similar correlations of the Upper Devonian / Lower Mississippian made previously by Harper and Laughrey (1987) in Allegheny, Washington, and Greene Counties and extends those relationships further east. 


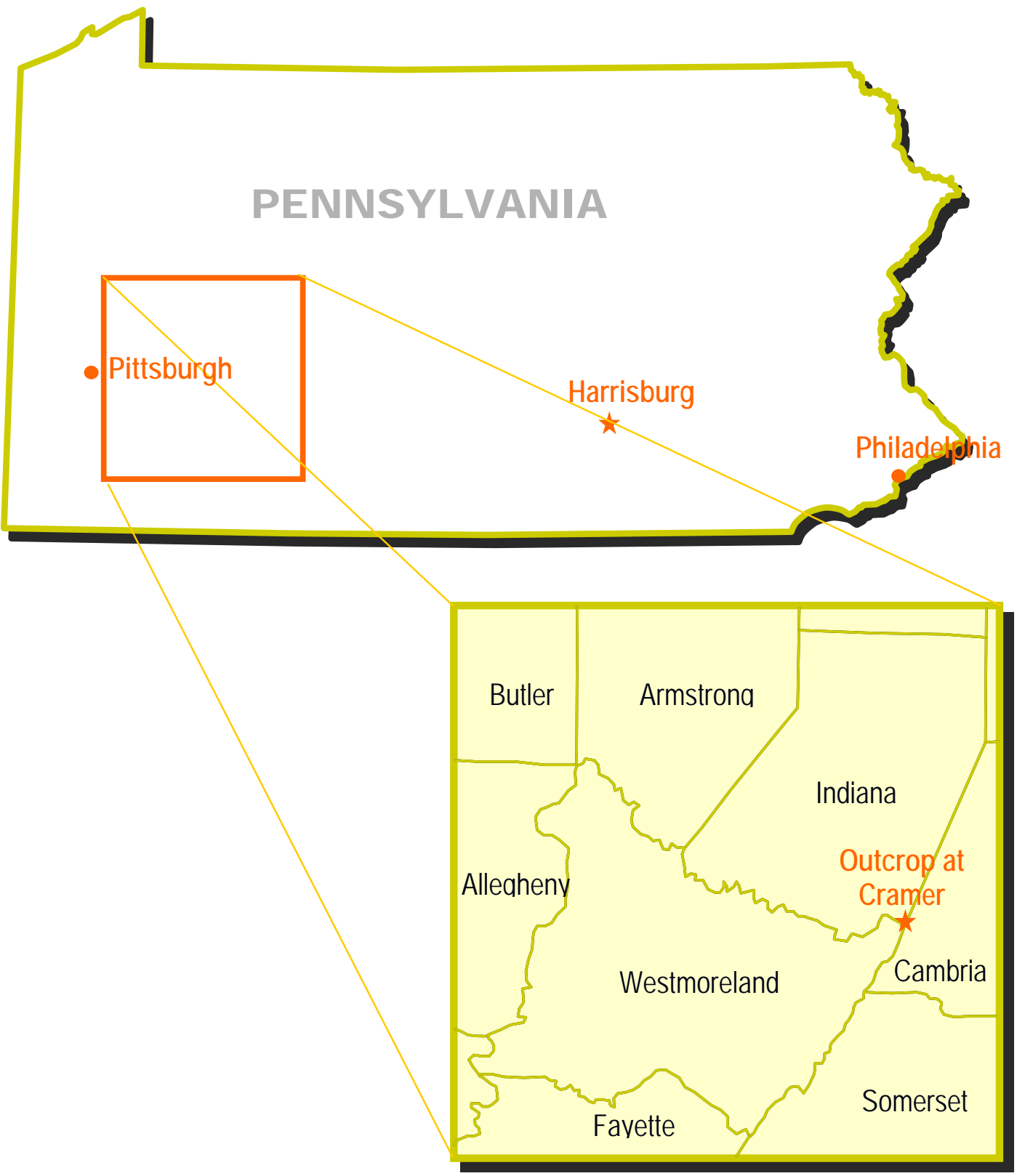

Figure 12. Study area in southwestern Pennsylvania showing the outcrop at Cramer, PA. 


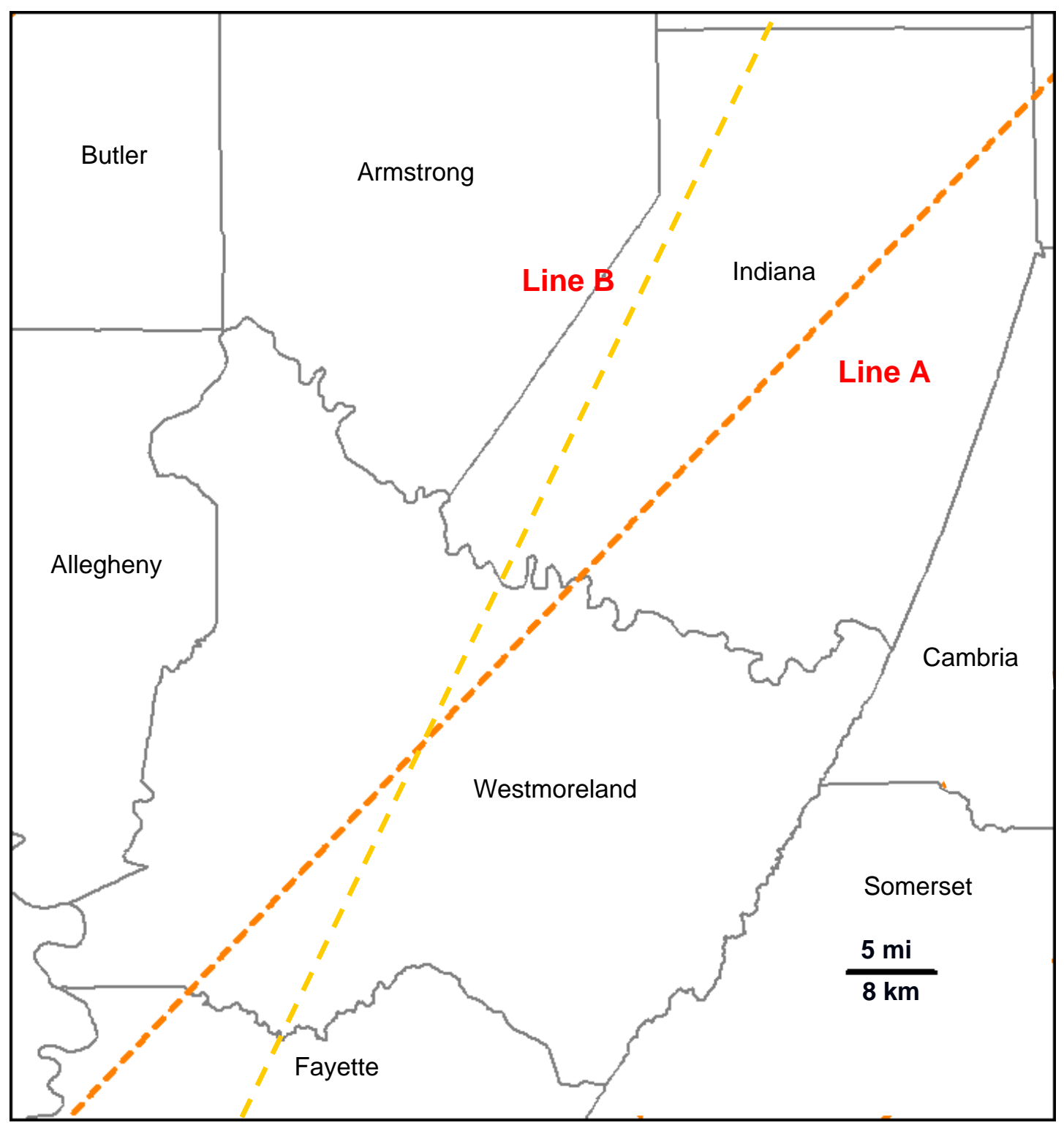

Figure 13. Line $A$ is the interpreted positioning of the eastern edge of the Rome Trough basement fault taken from Flaherty (1996.) Line B is the revised fault positioning based on data from this study. In general, the fault trace runs northeast-southwest. 


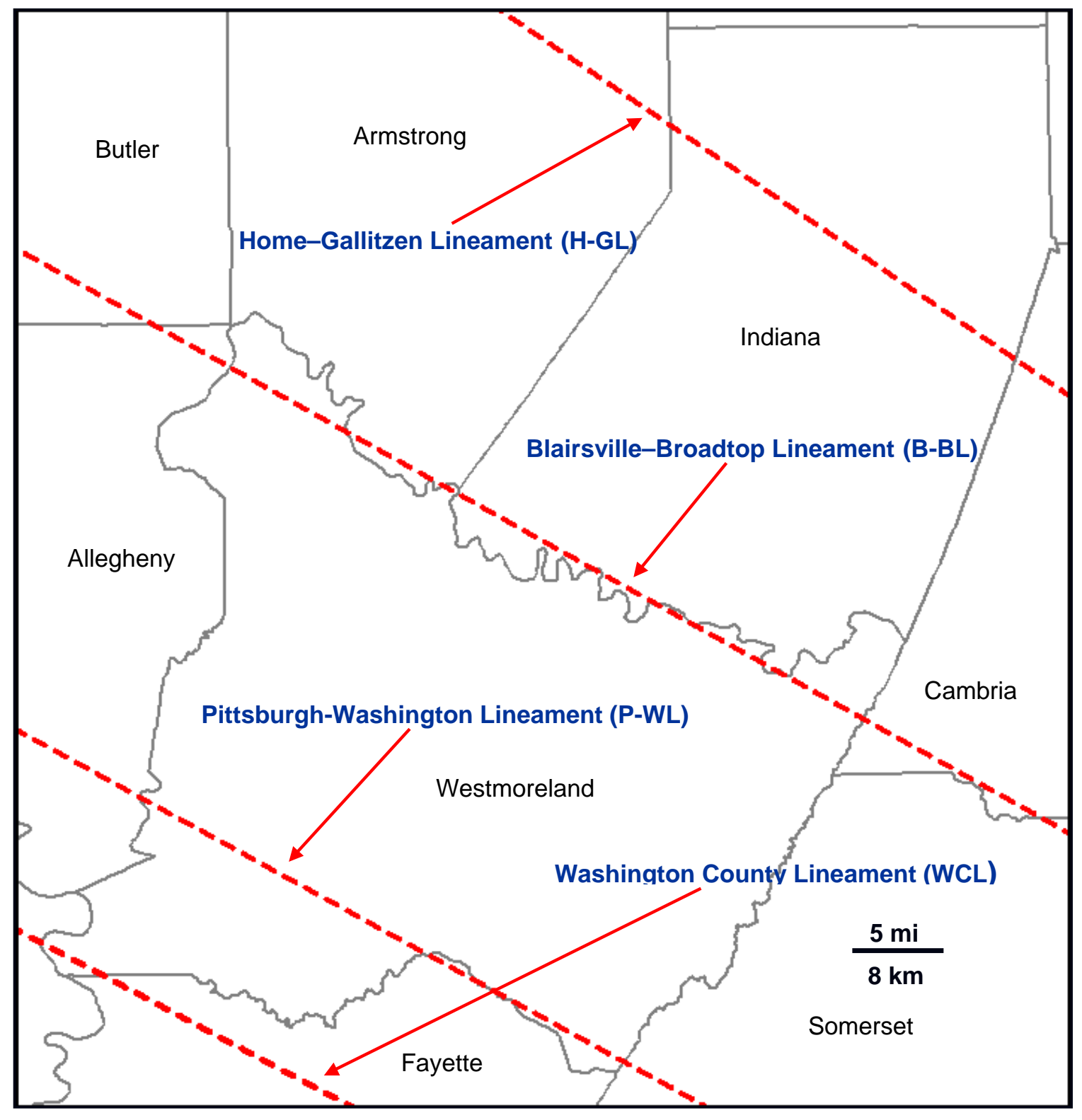

Figure 14. Inferred positions of lineaments within the study area. (Adapted from Flaherty, 1996.) 


\section{Method of Investigation}

The largest portion of available data came from geophysical logs utilizing the gamma-ray curve, and provided the simplest method of correlation over such a large area. Approximately 200 gamma-ray logs were utilized throughout the study (Figure 15). Where available, the author utilized density, neutron, and resistivity data to better confirm the nature of each sedimentary package to aid in correlation. Well logs for this study were predominantly taken from proprietary data obtained from Dominion Exploration and Production, Inc. (DEPI.) Where there are gaps in well-log data obtained from DEPI, additional wells were obtained from the Oil and Gas Division of the Pennsylvania Geologic Survey located in Pittsburgh, PA, as well as data from local oil and gas companies in western Pennsylvania.

One additional tool was the use of sample logs taken from various locations around the study area. Not only did they provide points of correlation, they also provided short lithologic descriptions that helped to identify one unit from another. Figure 16 is one such example of a sample log from Westmoreland County that was used to tie the outcrop data to the well log data.

In addition to well-log and sample-log information, an outcrop at Cramer, PA (along the Westmoreland and Cambria County borders) aided in tying well log correlations to a physical description of the Hundred Foot, Murrysville and Weir sandstones (Figure 17.) Approximately 100 feet (30 m) of Murrysville and 50 feet (15 m) of Weir sandstone, in addition to the Upper Venango Hundred Foot, are exposed at this location that is situated on the western flank of the Laurel Hill anticline. This is, unfortunately, the only good-quality outcrop that can be used for correlation ties, since there are no easily accessible equivalent outcrops within the study area. A detriment to this study is the paucity of subsurface data in the way of full-bore cores, which would lend themselves to environmental interpretation models beyond those proposed in this study.

The first and most critical step of this work involved the gathering and correlation of well logs throughout the study area. Figure 18 is the type log from the large Murrysville storage field in Westmoreland County used as the basis for the correlations in this study. All three zones of interest are represented here, especially the Hundred Foot and Murrysville. The Weir sandstone is the thinnest of the three zones in the type log because it is some distance westward of the main sandstone trend. 


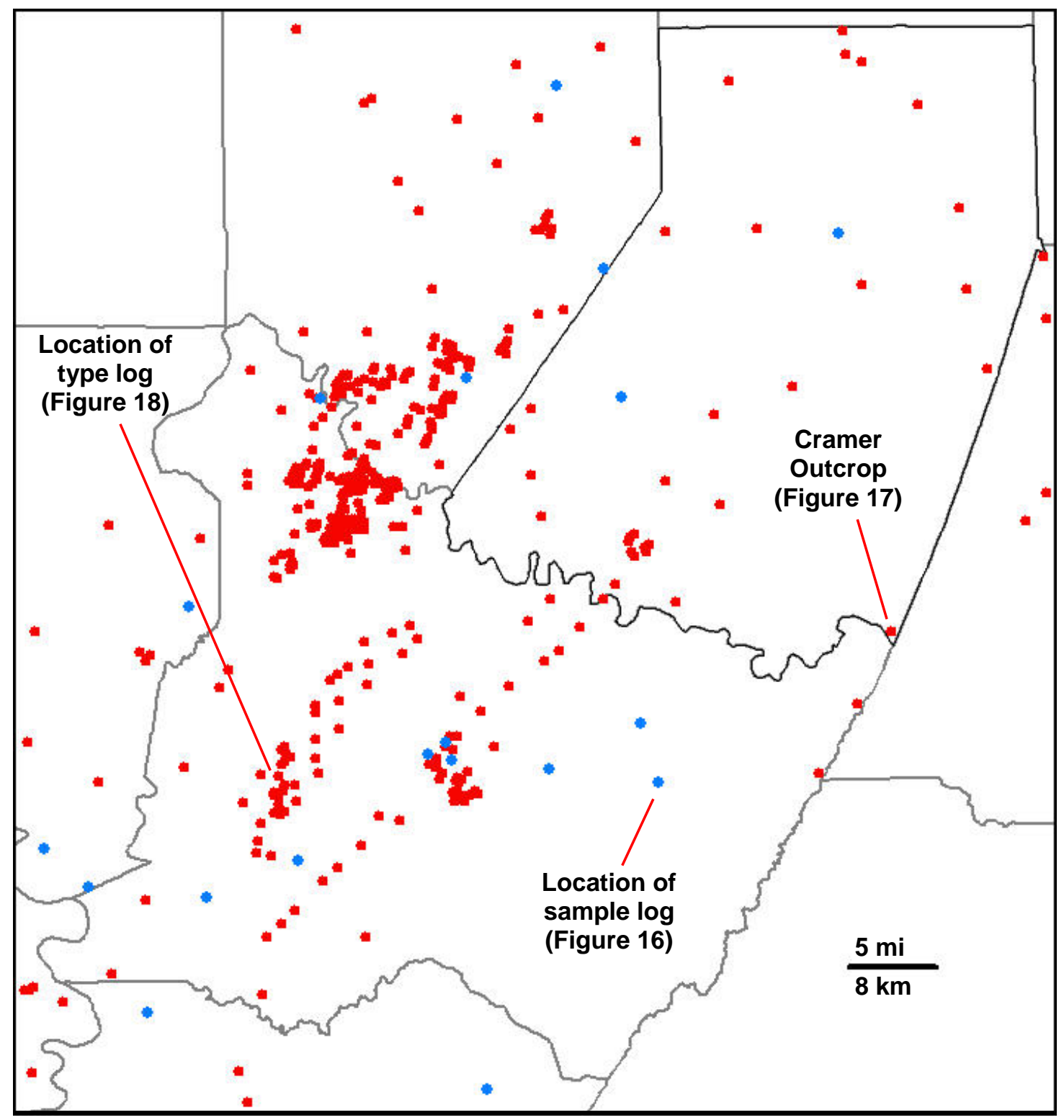

Figure 15. Position of data control points from well logs (in red) and sample logs (in blue) used in this study. The outcrop at Cramer, the type log, and a sample log used in the study are also shown. 


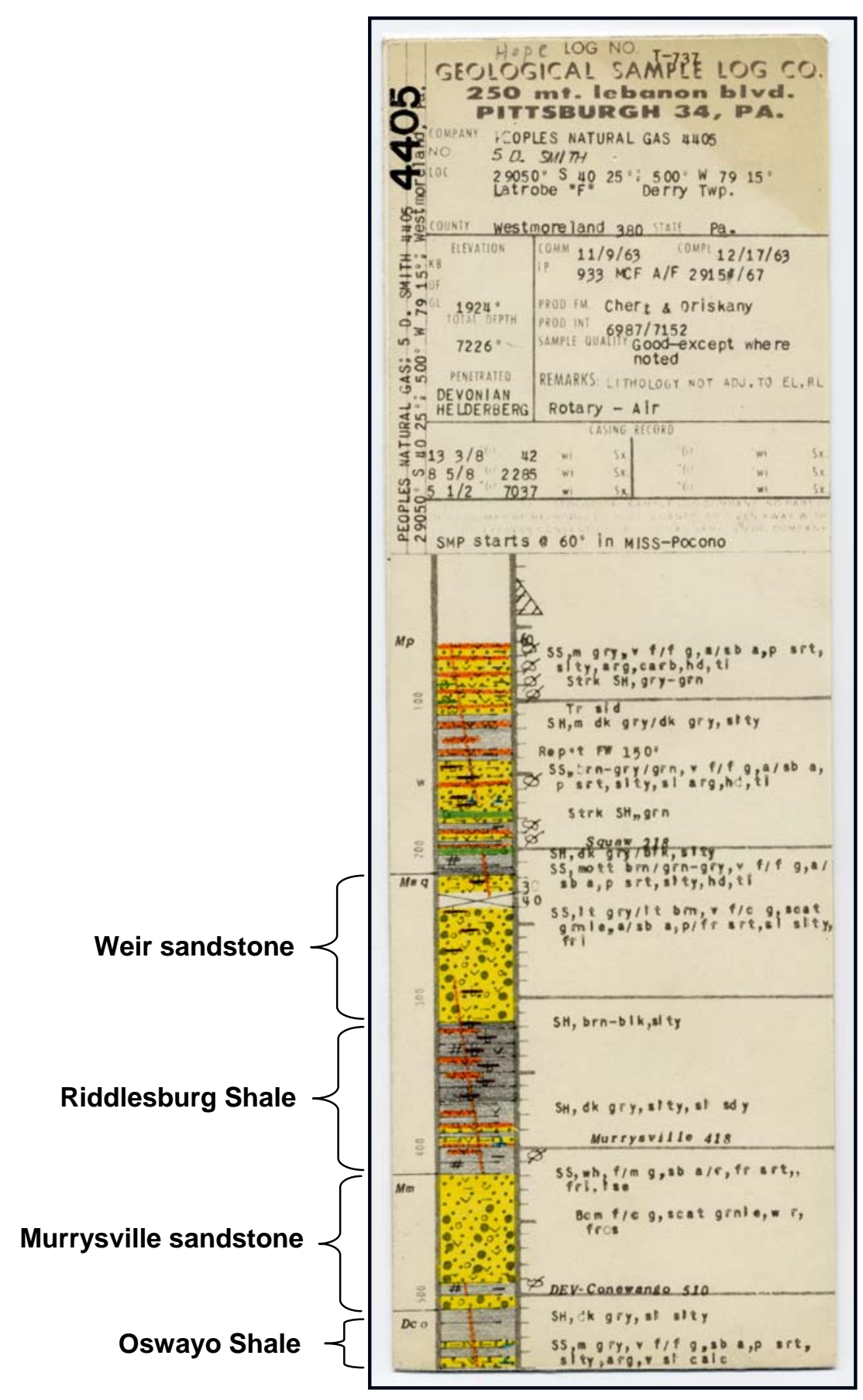

Figure 16. Sample log (PNG \# 4405) from Westmoreland County used in correlation of cross-sections and isopach mapping (from the Geological Sample Log Co., 1963.) 


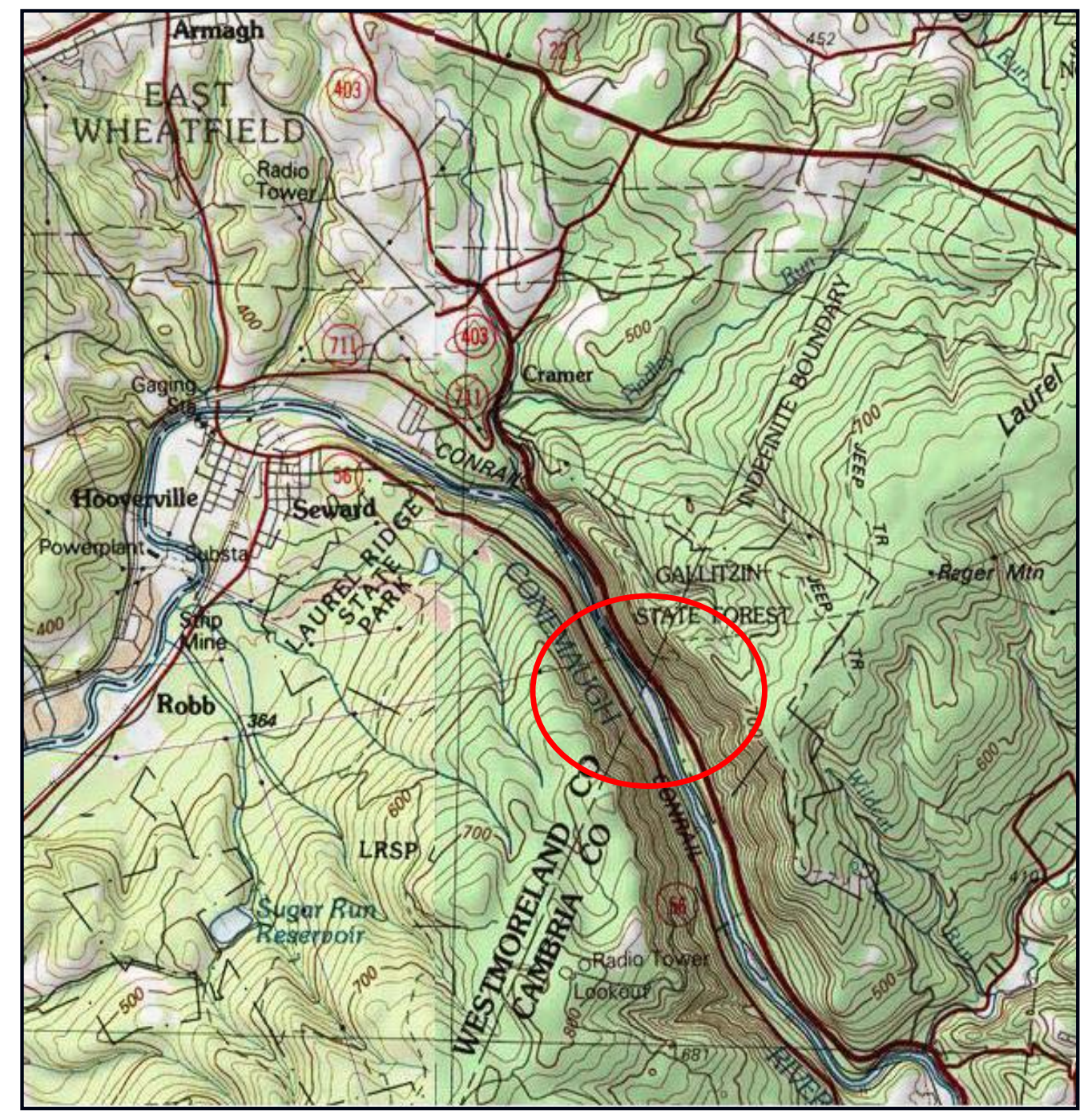

Figure 17. Location of Upper Devonian-Lower Mississippian Venango, Murrysville, and Weir outcrops in the Conemaugh Gorge area. 


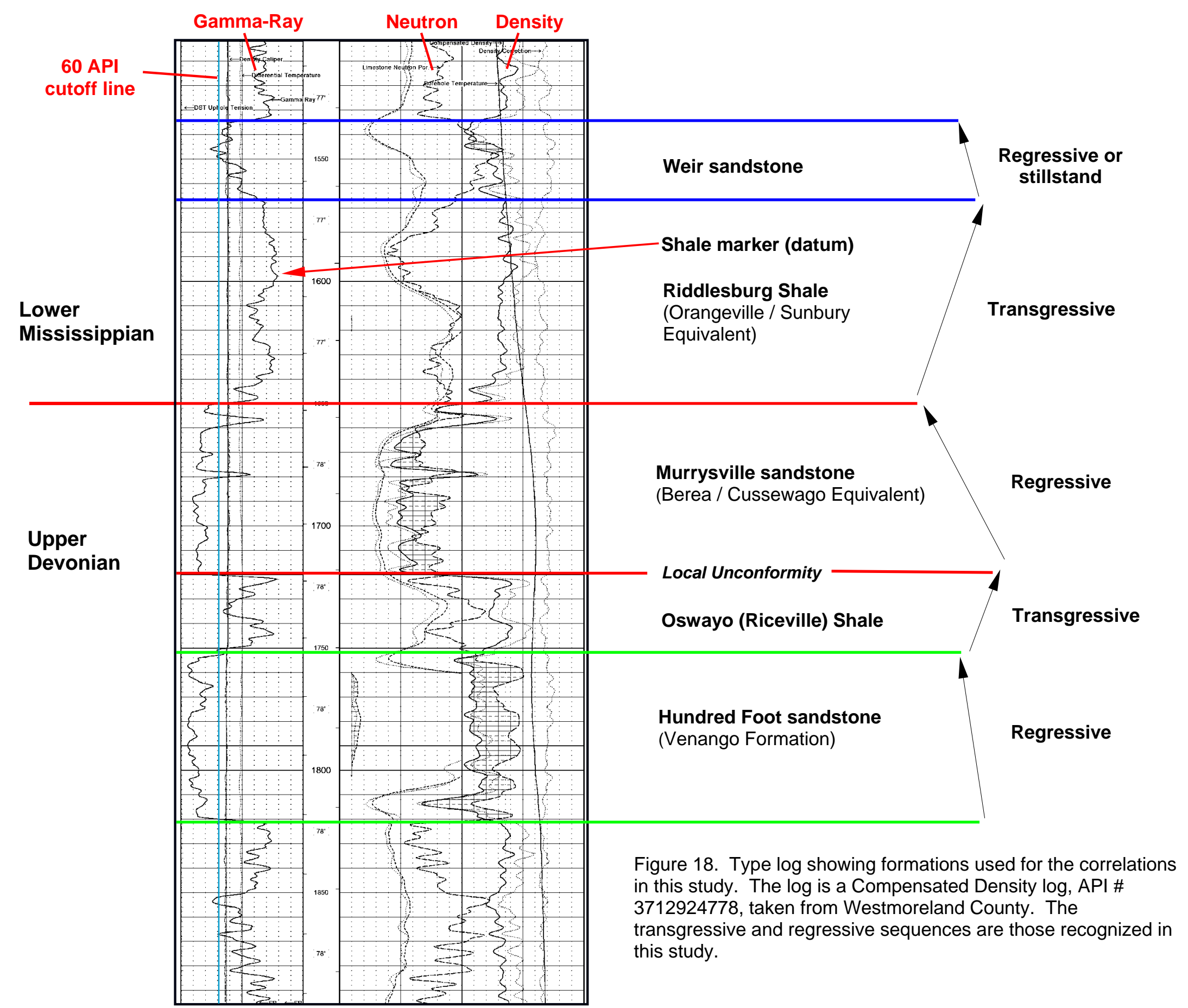


These selected zones were then correlated from the central area in Westmoreland County using the closed-loop method. The largest portion of the data was obtained from gamma-ray logs.

Sandstone tops and bottoms were determined as well as net sand thickness for each sediment package. The author chose a cutoff value of 60 API units to represent "clean sand" throughout the interval. The thickness of each section below the 60 API cutoff were added together to produce the net sand thickness. Although in a given interval there may be multiple layers of sand separate from one another, the several layers were summed together, ignoring any breaks, to produce a total sand thickness for each stratigraphic unit. The separate layers, however, were resolved within the cross sections.

Due to differing vintages of well-log data, an attempt was made to normalize curves where they appeared to be too high or too low in API units from the standard type curve. Once the net sand values were interpreted from each log, these data were loaded into GeoGraphix ${ }^{\mathrm{TM}}$ software, and a series of structural and isopach maps for each lithologic unit were generated. Gross sand maps were created for the Hundred Foot, Murrysville, and Weir sandstones, as well as a subsea map of the structural top of the Murrysville. Isopach maps of the gross shale interval for the Oswayo Shale and Riddlesburg Shale were also generated. Structural lineaments and basement faults were then superimposed on these data to make inferences about structural controls on deposition.

Eight cross-sections were generated, five strike lines and three dip lines (Figure 19), by digitizing selected gamma-ray curves along a proposed section and importing these data into GeoGraphix ${ }^{\mathrm{TM}}$ software. The original paper well logs were scanned, calibrated, and digitized in Neuralog ${ }^{\mathrm{TM}}$ software. Interpolation between gamma-ray logs was run in order to amplify common characteristics in each well. Positioning of the dip sections was controlled by the geometry of the isopach maps that were created previously; mainly to generate sections that were either "on-trend" or "off-trend," especially for the Murrysville sandstone. This enabled comparisons to be made between the stratigraphic sections that highlighted their depositional similarities and/or differences. Crosssections A-A', F-F', and G-G' were correlated from the outcrop to logs along strike and dip, respectively. 


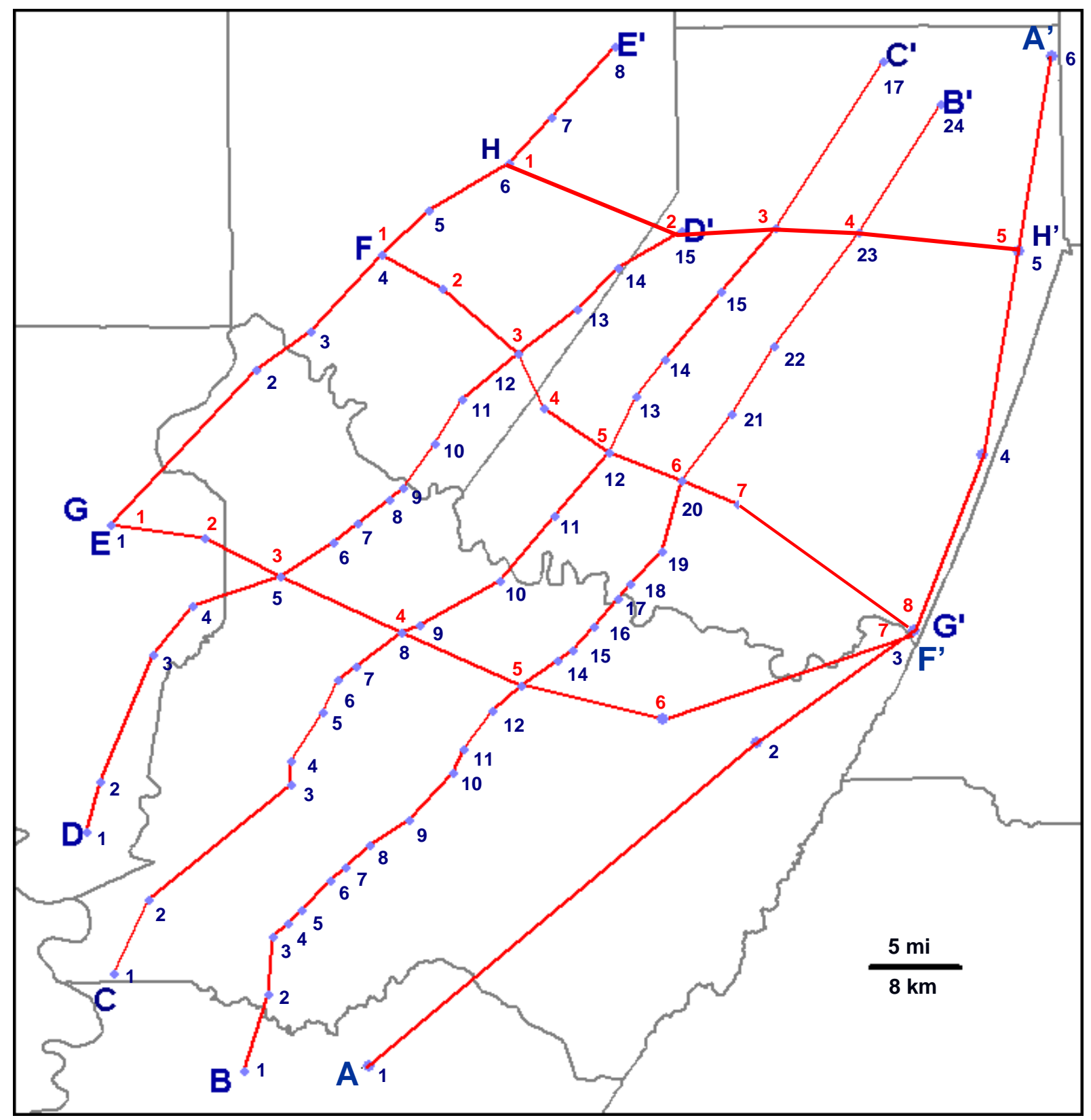

Figure 19. Index line map for the eight cross sections generated in this study. See the Appendix for further information on each well used in the cross sections. 
One difficulty in generating the cross sections in this study was the selection of the datum. A mundane, but crucial point, it was especially difficult in this study area where wildly discontinuous sandstones and shales exist throughout the stratigraphic section. The datum in this study is a marker in the Riddlesburg Shale that appears more or less widespread in the study (Figure 18.) Although some of the log markers varied greatly from one to the next, there was enough consistency to use this as a somewhat reliable datum. 


\section{Measured Sections at Cramer, PA}

Harper et al. (1989) presented an excellent description of Upper Devonian and Lower Mississippian depositional systems in southwestern Pennsylvania, especially those exposures of the Venango Formation, Murrysville and Weir sandstones in the Conemaugh Gorge near Cramer, PA. Whereas the outcrop description is not a central focus of this paper, it is crucial in correlating and interpreting the isopach maps generated by subsurface information as well as correlating the cross sections. Therefore, it is worthwhile here to present a brief description of the findings as presented by Harper et al. (1989). The key to the outcrop symbols can be found in Figure 20.

\section{Hundred Foot Section}

Approximately $125 \mathrm{ft}(40 \mathrm{~m})$ of section of the Hundred Foot interval is exposed at Cramer and is presented in Figure 21. The lowermost 57 feet $(17 \mathrm{~m})$ of the Hundred Foot sandstone contains interbedded sandstones, siltstones, and shales thought to represent nearshore tidal-flat, shoal, and tidal-channel deposits (above) with estuarine and fluvial deposits (below.) This section contains abundant brachiopod fossils as well as fish remains and vertical and horizontal burrows. The next $67 \mathrm{ft}$ (20 $\mathrm{m}$ ) of section that lies just below the Murrysville is the Oswayo, which is comprised mostly of shale, with a few interspersed sand bodies. The Oswayo Shale is thought to represent a restricted-marine environment, and contains occasional brachiopod and crinoid remains as well as burrowing traces. As we shall see, the Hundred Foot section, described as the Upper Sandy Zone by Harper et al., 1989, does not show the same depositional environment that log analysis and isopach interpretation suggest in areas farther west.

\section{Murrysville Section}

Figure 22 is the measured section from the Cramer outcrop showing almost 100 feet $(30 \mathrm{~m})$ of exposed Murrysville section and includes sedimentary features and their interpreted facies. The unit is dominated by trough-cross-bedded, pebbly sandstone at its base, namely the Cussewago equivalent. Approximately 65 feet $(20 \mathrm{~m})$ of Cussewago is exposed that comprises mostly fine- to coarse-grained sandstones with noticeable trough cross-bedding features. There is a scoured base at the bottom of the Murrysville that may represent a disconformity at the underlying Oswayo Shale section. The only fossils noted in this section are plant debris, a factor that suggests a nonmarine environment. This 


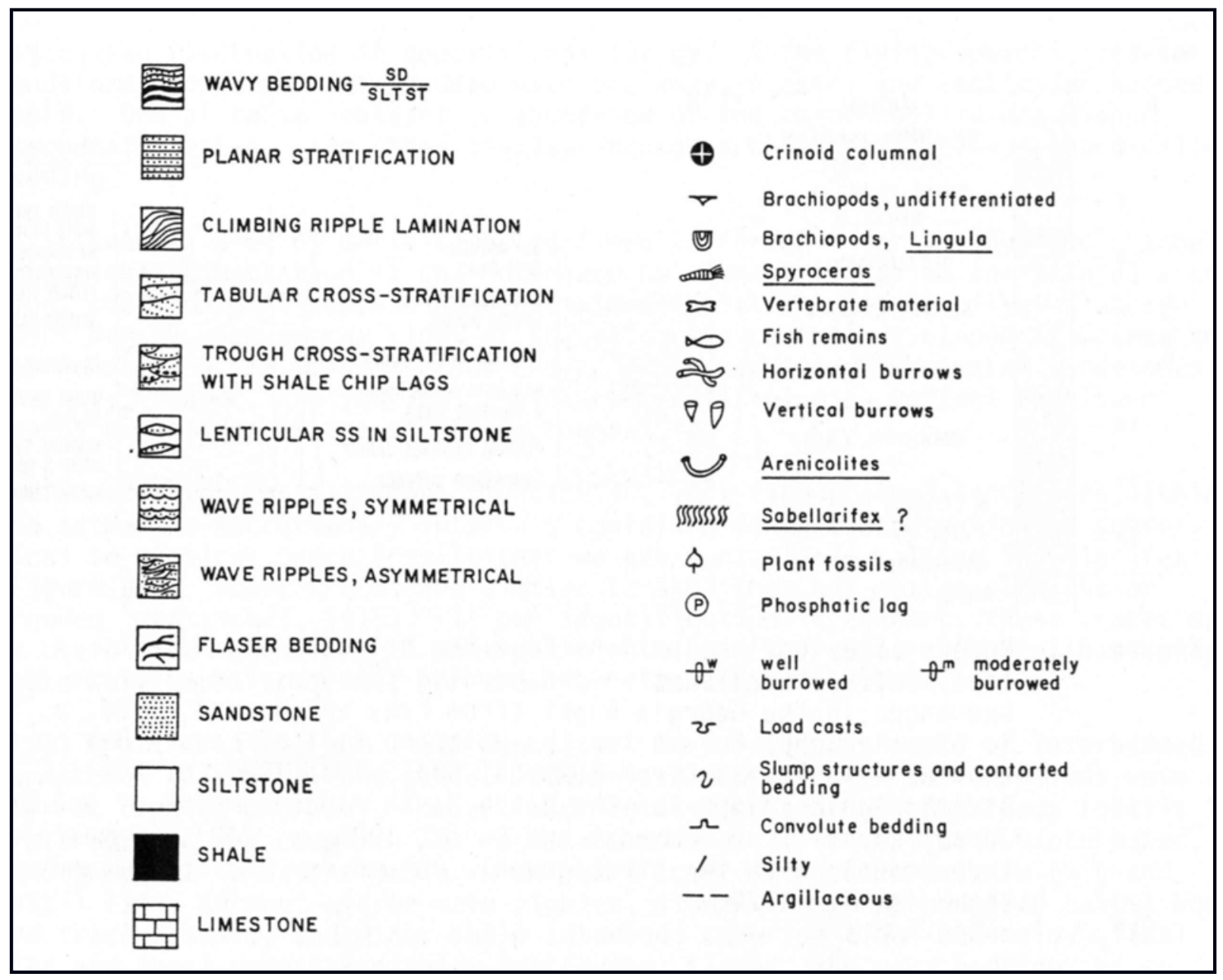

Figure 20. Key to symbols of the measured sections found in Figures 21, 22, and 23 (from Harper et al., 1989.) 

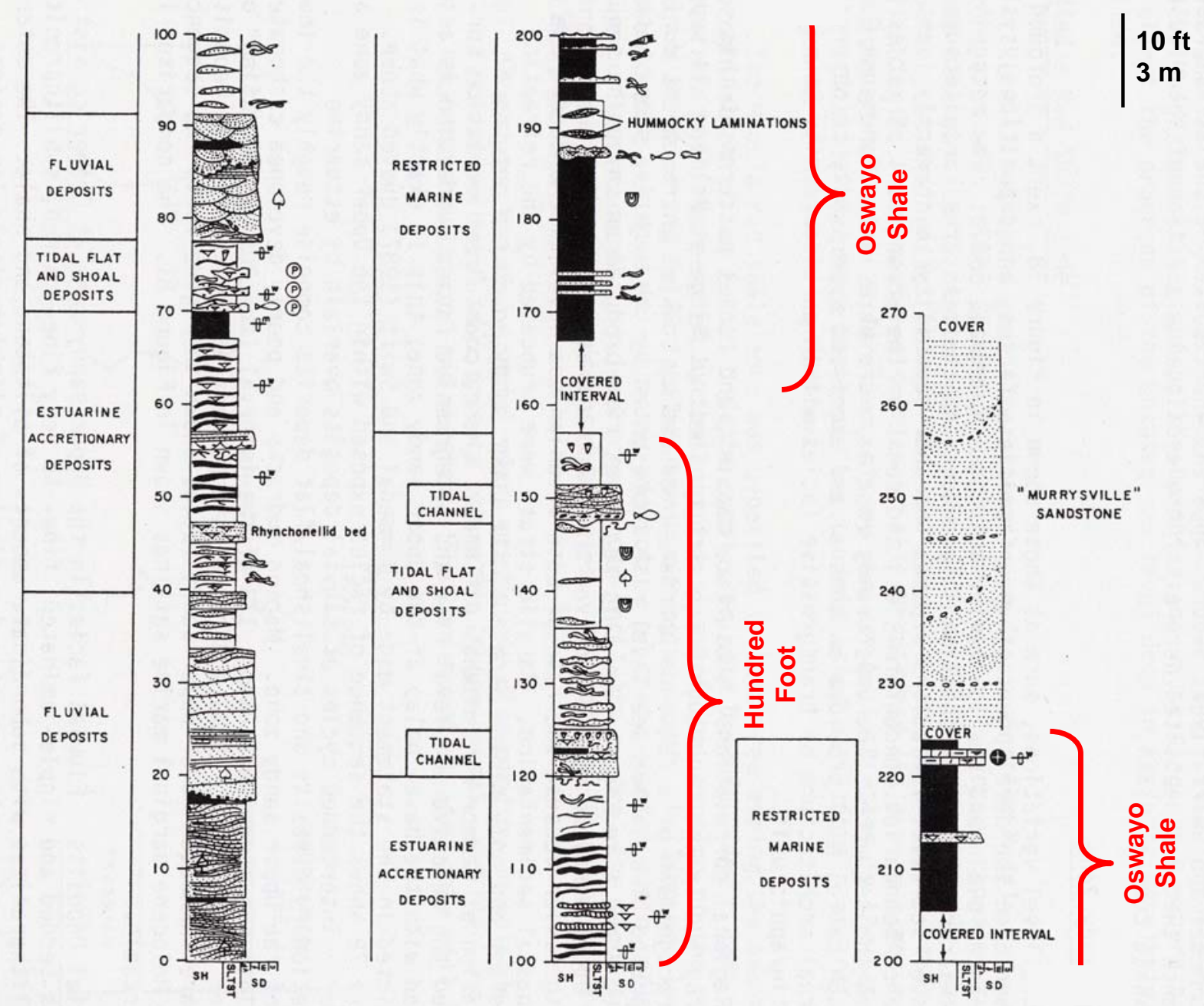

Figure 21. Measured section of the Hundred Foot (Venango Group) near Cramer, PA. The Hundred Foot in the western portion of the study (interpreted as a barrier-bar in this study) is dramatically different than the measured outcrop that is interpreted to be tidal-flat and shoal deposits with associated channels (from Harper et al., 1989.) 


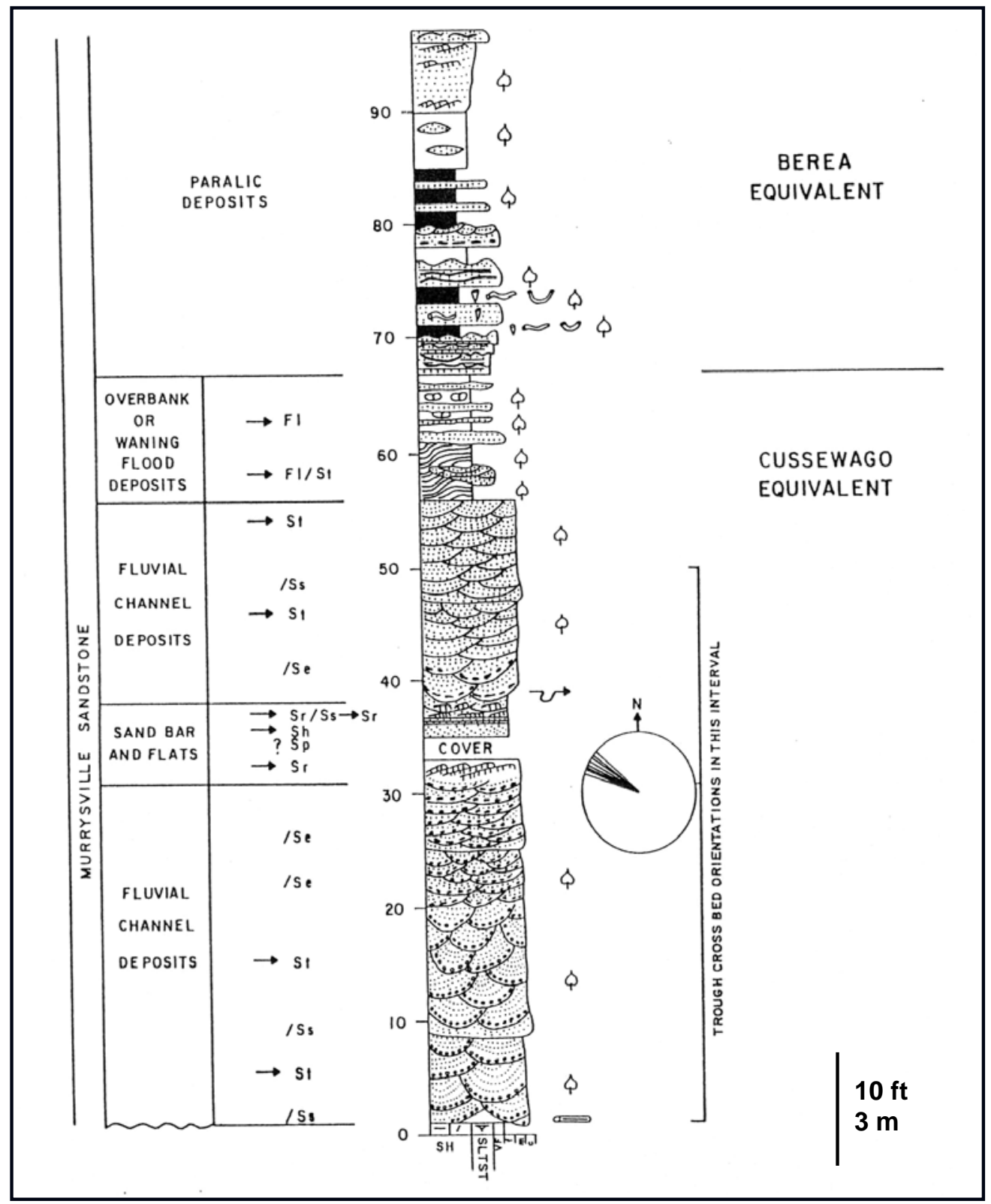

Figure 22. Measured section of the Murrysville near Cramer, PA. The Cussewago section has been interpreted as a braided stream deposit with dominant current direction to the northwest. The upper Berea section is interpreted to be paralic, likely indicating the beginning of sea-level rise prior to Riddlesburg Shale deposition (from Harper et al., 1989.) 
lower portion of the Murrysville has been interpreted as a braided-channel deposit with the dominant current direction, as measured from the cross-bedding, to the northwest. A small section of planar bedded sandstone with subjacent ripple-marked sandstone occurs in the middle of the massive fluvialchannel section, and has been interpreted as a sand bar and flat. The uppermost section of the Cussewago equivalent grades upward into fine sandstone, siltstone, and mudstone all of which display fine laminations and ripple marks with associated plant fossils. This upper section has been interpreted as overbank and flood deposits.

The Berea equivalent section (Figure 22) is markedly different from the underlying Cussewago, and may represent a post-Murrysville flooding surface. This section includes sandstone, siltstone, and shale with wave and current ripples, flaser, wavy and lenticular bedding, in addition to scour surfaces and rip-up clasts. Plant debris and trace fossils are common throughout this section. This section has been interpreted as a paralic, marginal-marine environment, and may represent the beginning rise in sea level that would eventually drown the Murrysville and associated sediments prior to deposition of the Riddlesburg Shale.

\section{Weir Section}

In addition to the Murrysville, the Weir sandstone section is also exposed in the Conemaugh Gorge near Cramer, PA. The measured section is shown in Figure 23. This exposure displays a classic coarsening-upward sequence that is evident not only in outcrop but on gamma-ray logs as well. The shales of the Riddlesburg grade upward and are conformable with the Weir sandstone above, with the Weir being almost $60 \mathrm{ft}(18 \mathrm{~m})$ in thickness. The lowermost sandstone of the Weir displays trough cross-bedding and it is interbedded with siltstones and shales. This section grades upward into sporadic shale, rippled sandstone, and scour-based conglomerate interbeds that are eventually capped by trough cross-bedded sandstones and a massive conglomerate section. The entire Weir section contains numerous horizontal trace fossils, and the subjacent Riddlesburg contains brachiopods, trace fossils and plant debris at the upper portion of the shale.

The Weir sandstone also exhibits "swell-and-pinch" structures within the sandstone sections. Although not described in detail, previous interpretations postulate that these bedforms may be 


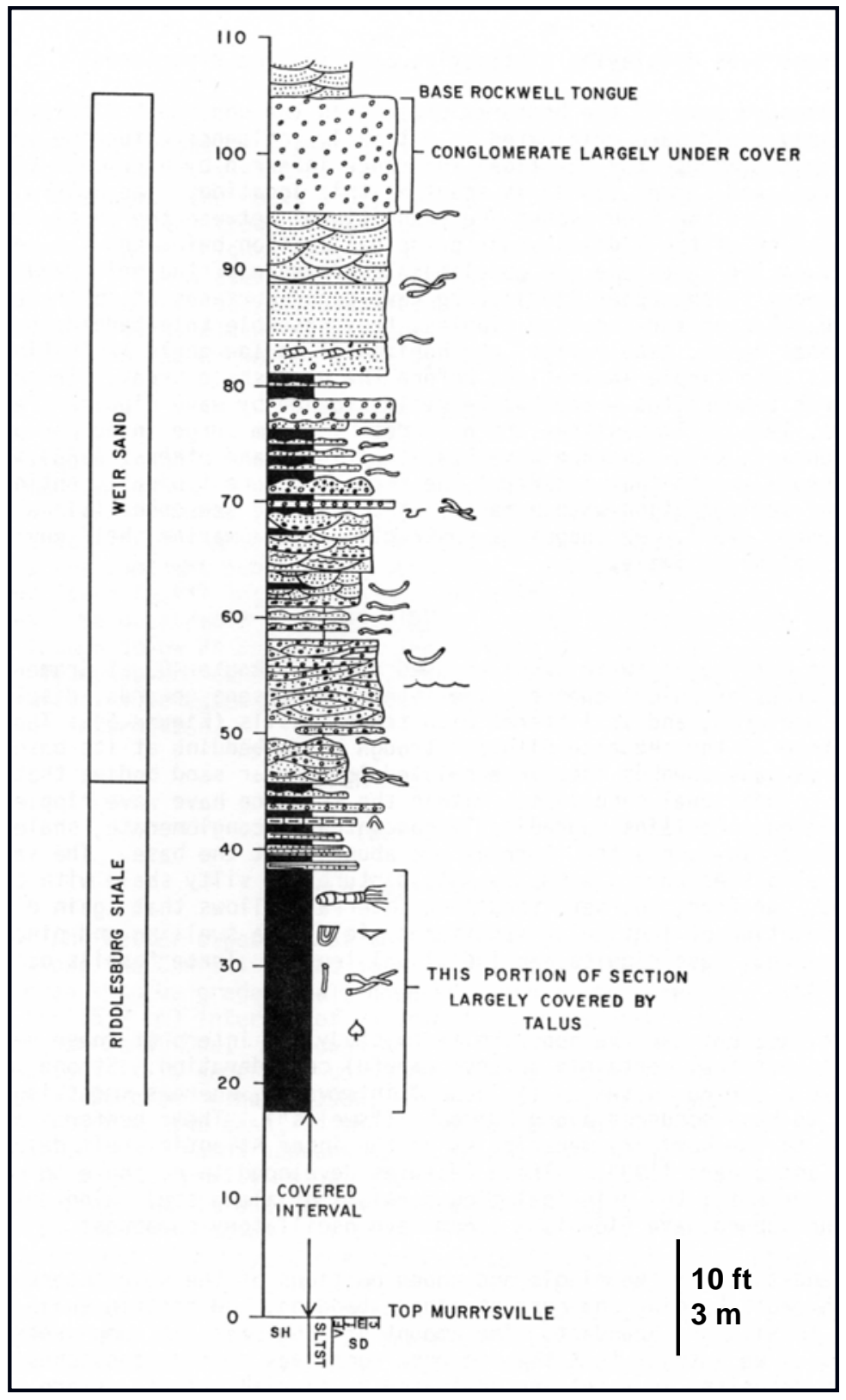

Figure 23. Measured section of the Weir near Cramer, PA. This section was originally interpreted as a mouth bar deposit suggested from its coarsening-upward sequence, but may actually be a shoreface complex as shown in this study (from Harper et al. 1989.) 
indicative of hummocky megaripples in an area of rapidly changing currents along a shelf environment. The Weir section has been described as "marine sandstones and conglomerates deposited in a setting dominated by fluvial output; upward coarsening originated through mouth-bar progradation" (Harper et al., 1989.) 


\section{Description and Interpretation of Isopach Maps}

\section{Hundred Foot sandstone Isopach Map}

Figure 24 is the isopach map generated for the Hundred Foot sandstone within the study area, and a number of features are apparent from its distribution. There are three roughly parallel sand bodies striking $\mathrm{N} 10^{\circ} \mathrm{E}$ with the thickest body, approximately 60 feet $(18 \mathrm{~m})$ thick, occurring near the study's western edge. The other, north-south trending sandstone bodies are smaller in size, and sit immediately to the east of the western trend. From these thicks, the sandstone thins to the east until there is only 10 feet $(3 \mathrm{~m})$ of sandstone at Cramer. Interestingly, this decrease in sandstone deposition to the east coincides with a proposed Rome Trough basement fault. Observations on similar Venango Formation sandstones in West Virginia (Boswell, 1985) show sandstone shoaling / thickened sections on or near proposed basement faults. Fault movement may have produced enough relief across the fault block (or blocks) to influence deposition.

There seems to be no direct correlation of the sand geometry with the lineaments identified in this study. One could make the argument that portions of the isopach show thinning near a lineament, especially along the Home-Gallitzen Lineament where the eastern trend terminates abruptly to the north, and along the Blairsville-Broadtop Lineament where the bar trend seems to be offset in northeastern Westmoreland County. Unfortunately, a lack of well control along the northern edge of the study may have created some bias in these areas. For now, the issue remains unresolved.

The linear geometry of the Hundred Foot suggests a barrier-bar system, and the blocky, clean character of the Hundred Foot in log section (Figure 18) supports this interpretation. Although the westernmost barrier-bar is not completely within the study area, the portion that falls within the study's boundaries is approximately 40 miles $(64 \mathrm{~km})$ in length, $5-7$ miles $(8-11 \mathrm{~km})$ in width, and about 60 feet (18 $\mathrm{m}$ ) of sand at its thickest point. The bars to the east are slightly smaller with the center bar being approximately 35 miles $(56 \mathrm{~km})$ long, 5 miles ( $8 \mathrm{~km})$ wide, and 80 feet $(24 \mathrm{~m})$ thick; the easternmost bar being approximately 35 miles $(56 \mathrm{~km})$ in length, 5-7 miles $(8-11 \mathrm{~km})$ in width and 80 feet $(24 \mathrm{~m})$ thick. The spacing between the barrier bars is approximately 5 miles (8 km.) Boswell (1985) has also described the Hundred Foot as a barrier-bar system in West Virginia. The two trends are probably linked and likely represent a large barrier-bar system that existed at the end of Catskill Delta deposition. 


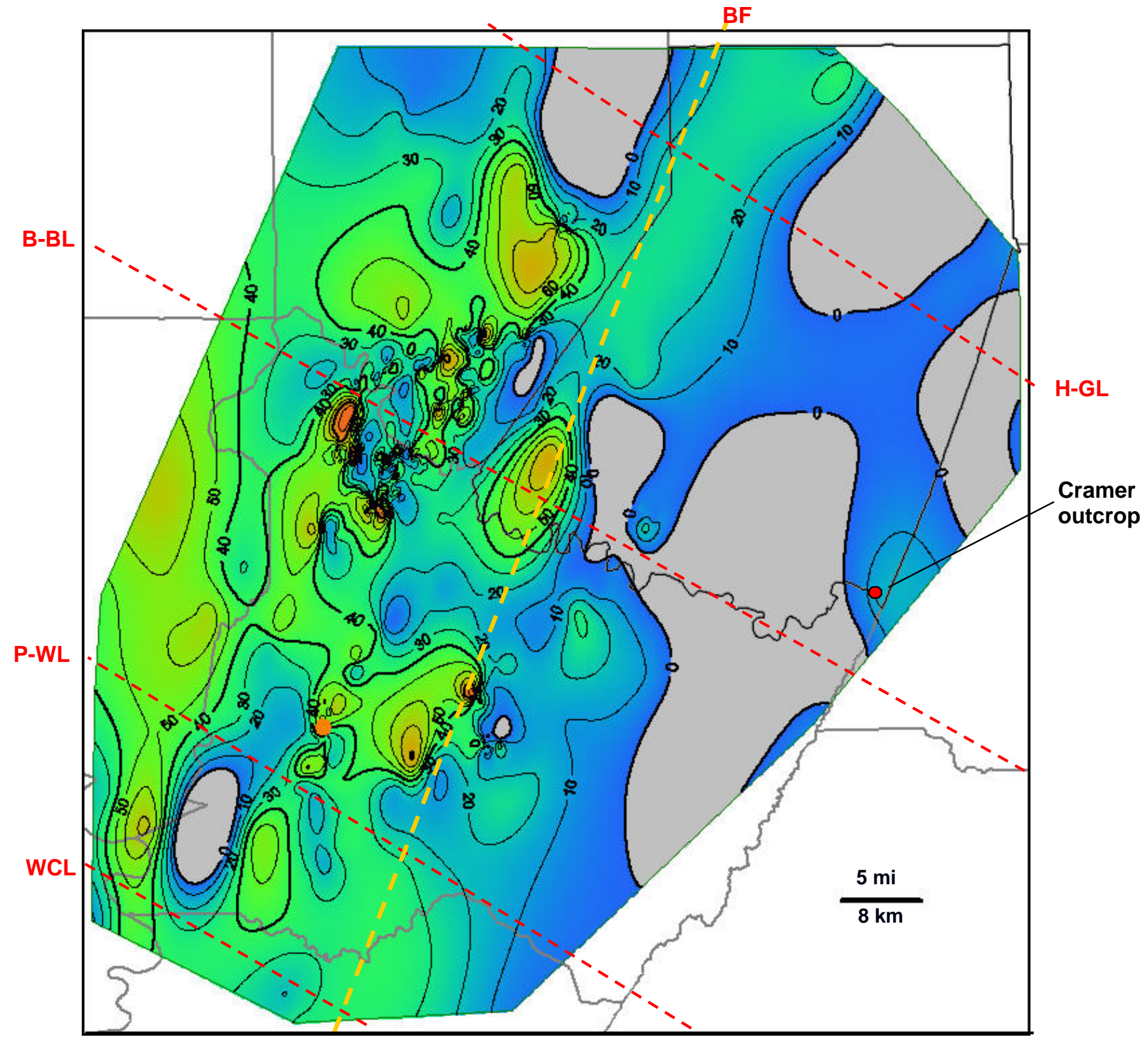

Figure 24. Isopach map of the Hundred Foot sandstone with superimposed lineaments and Rome Trough basement fault. Notice that there is very little sandstone east of the proposed basement fault. It is unclear from the data if the changes in sandstone thickness near the Blairsville-Broadtop Lineament (B-BL) and the Pittsburgh-Washington Lineament (P-WL) were influenced by the lineaments themselves. There is however, a noticeable eastward thinning of the sandstone as it crosses the basement fault. Cool colors represent thin sandstones and warm colors are thick sandstones. The contour interval is $10 \mathrm{ft}$. ( $3 \mathrm{~m}$.) 
There are also two sandstone bodies that occur to east of the easternmost bar trends, perhaps suggesting flood-tidal deltas.

Despite the lack of a thick, clean sandstone at the Cramer outcrop, the tidal-flat and tidalchannel sandstones, siltstones and shale below the Oswayo Shale may be correlative to the Hundred Foot farther west. The tidal-flat and tidal-channels described by Harper (1989) may represent the tidalinfluenced lagoon behind the barrier-bar system. The main shoreline was likely to be farther east of Cramer at the end of Catskill deposition.

\section{Oswayo Shale Isopach Map}

Figure 25 is the isopach map generated for the marine, Oswayo Shale that caps the Hundred Foot sandstone across much of the study area. The isopach was generated by calculating the amount of shale from the top of the Hundred Foot sandstone to the base of the Murrysville sandstone. In general, the thickest shale interval lies in the western part of the study area, approximately 60 feet (18 $\mathrm{m})$, and thins eastward. The post-Hundred Foot flooding event would have deepened the basin on the western side and increased the accommodation space for shale deposition. In the eastern area of the study, especially at Cramer, PA, there is about 50 feet $(15 \mathrm{~m})$ of shale at this location as well. Just to the west of the outcrop and throughout a significant portion of the eastern area of the study, the Oswayo shale thickness becomes unreliable. In this area, the Oswayo Shale lies directly on the lagoonal shales behind the Hundred Foot barrier bar system and becomes difficult to distinguish by log signature alone. Also evident from the isopach map is the thinner shale section in Westmoreland County and portions of Indiana County. In this area the Oswayo ranges from 10-30 feet (3-9 m). This thin section may reflect some scouring and removal of the upper portion of the Oswayo Shale by the superjacent Murrysville fluvio-deltaic system whose main axis of deposition coincides with the thinner Oswayo.

\section{Murrysville Isopach Map}

The isopach map generated for the Murrysville (Figure 26) is strikingly different from the Hundred Foot sandstone discussed previously. Immediately evident is the dominating direction of deposition. In the eastern portion of the study, the Murrysville displays a $\mathrm{N} 90^{\circ} \mathrm{W}$ orientation with an 


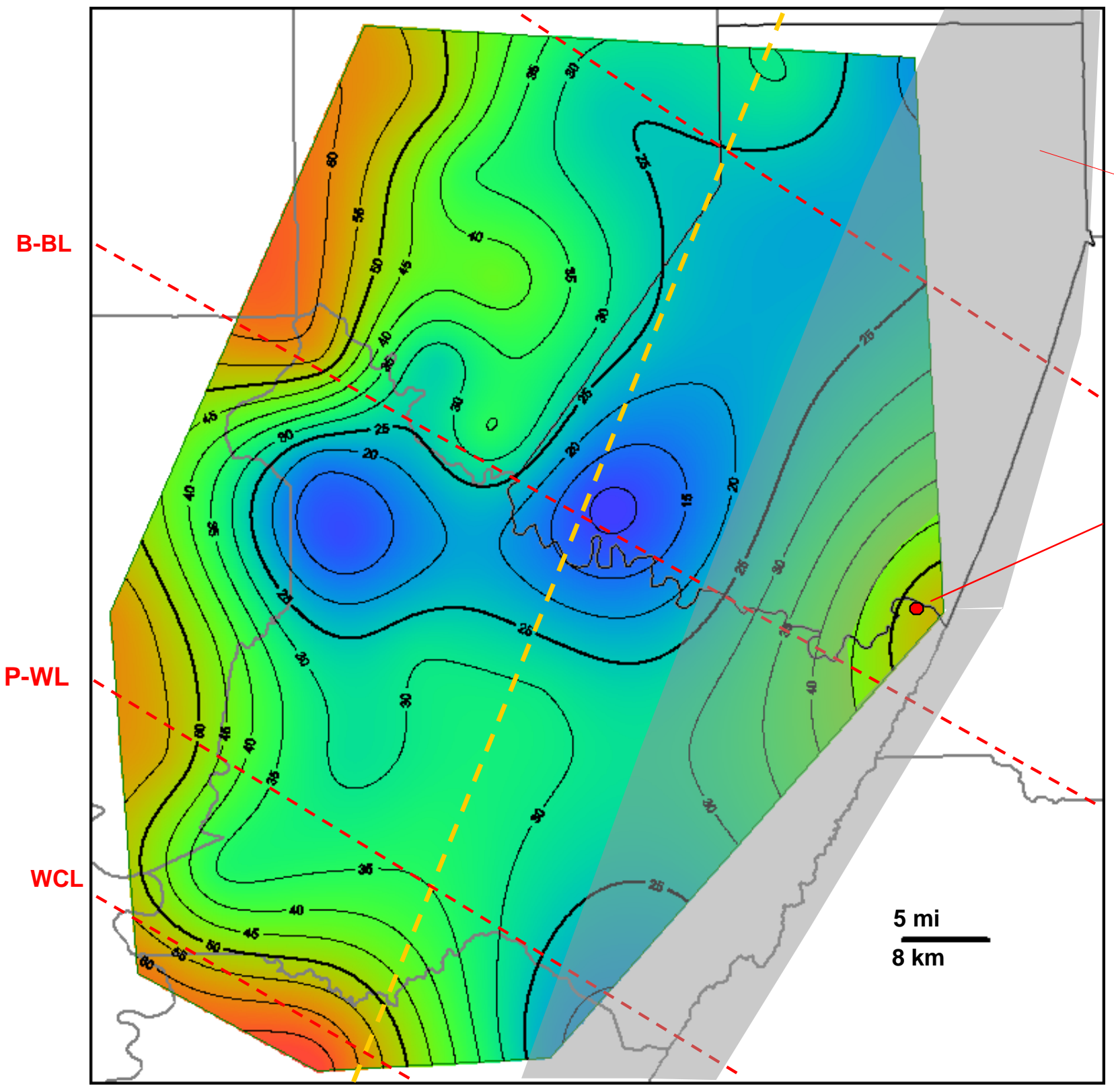

Unreliable data area

H-GL

Cramer outcrop

Figure 25. Isopach map of the Oswayo Shale. In general, the Oswayo thickenes to the west. The thicknesses in the eastern section of the study (gray shaded area) become unreliable as the Oswayo interfingers with the Hundred Foot lagoonal facies to become one large shale package. The thin shale section across northern Westmoreland County may be evidence that the superjacent Murrysville may have scoured and removed the upper portion of the Oswayo. Cool colors represent thin shale and warm colors are thicker shale. The contour interval is $5 \mathrm{ft}$. $(1.5 \mathrm{~m}$.) 


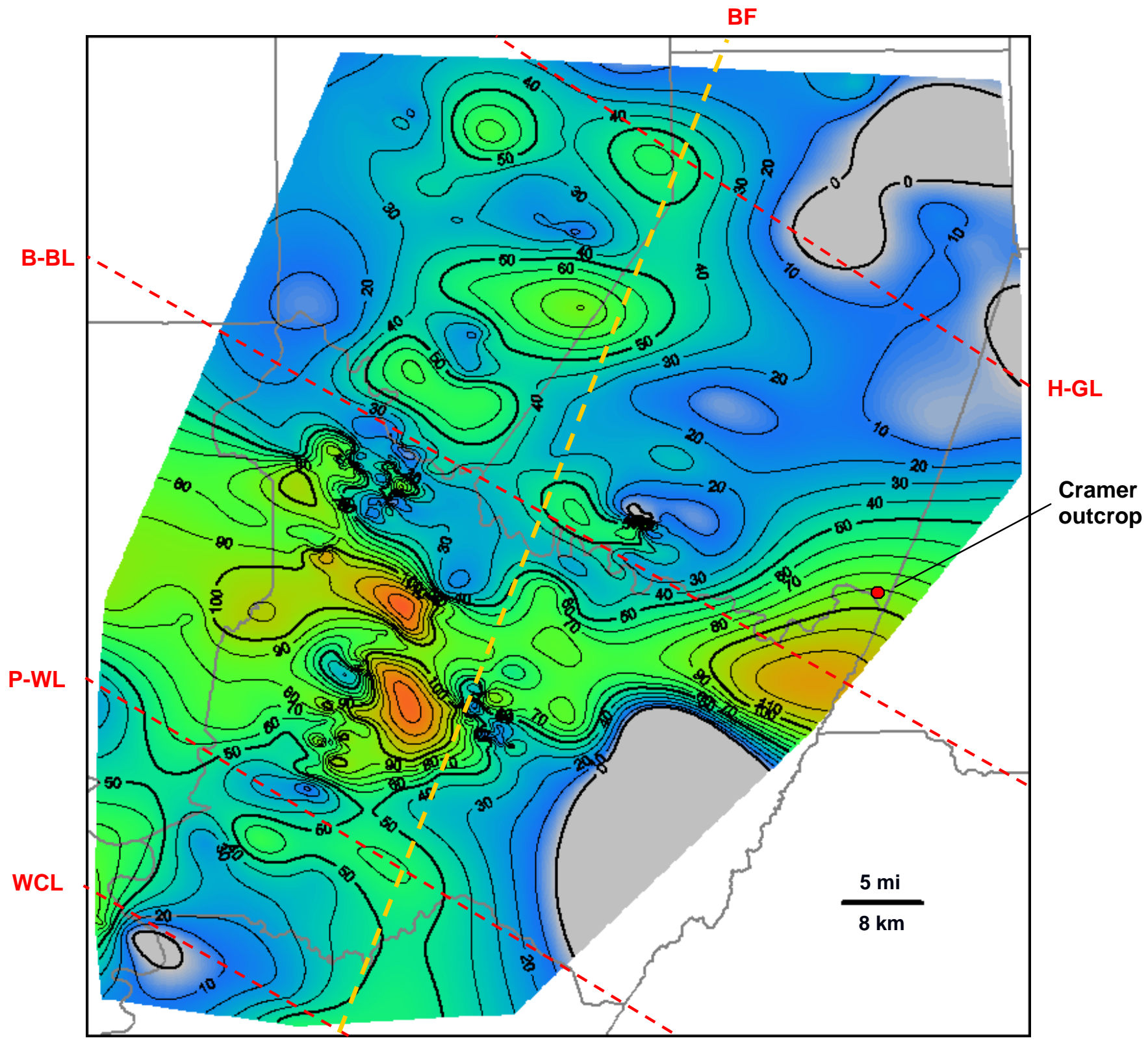

Figure 26. Isopach map of the Murrysville sandstone with superimposed lineaments and basement fault. Notice that the thickest sand portion is between the Blairsville-Broadtop Lineament (B-BL) to the north and the Pittsburgh-Washington Lineament (P-WL) to the south. Also notice a thickened sequence just to the west of the inferred basement fault, suggesting a slightly downthrown western block. Cool colors represent thin sandstones and warm colors represent thick sandstones. The contour interval is $10 \mathrm{ft}$. $(3 \mathrm{~m}$.) 
abrupt change of direction to $\mathrm{N} 60^{\circ} \mathrm{W}$ near the proposed basement fault. The Murrysville in the eastern portion of the study has fairly narrow shape, approximately 5 to 10 miles $(8-16 \mathrm{~km})$ in width in eastern Westmoreland County, whereas deposition to the west shows greater lateral accumulation, approximately 19 miles (31 km), in western Westmoreland County and into Allegheny County.

The map also shows distinctive sand thins at the southern Armstrong and Indiana County borders as well as at the southern border of Westmoreland County. It is postulated that this thinning occurred primarily due to cross-structural lineaments that were acting as lateral barriers during deposition. Figure 26 also shows the Murrysville isopach with superimposed lineaments. The Blairsville-Broadtop Lineament and the Pittsburgh-Washington Lineament may have had slight relief, producing these thins during deposition of the Murrysville. An elevation change on the order of a few feet between the northern and southern sides of the lineament would be enough to restrict and channelize flow, especially if we accept that the Murrysville at Cramer represents braided-stream deposition (Harper et al., 1989.) Continuation of Acadian tectonism would have provided the needed relief to allow braided streams to form. The narrow eastern channel is oriented near the BlairsvilleBroadtop Lineament; however, the isopach map suggests that the Murrysville may have cut obliquely across the lineament in a southwestern direction. The paleocurrent directions at the Cramer outcrop range from $\mathrm{N} 40^{\circ} \mathrm{W}$ to $\mathrm{N} 60^{\circ} \mathrm{W}$, an observation that also fits with isopach measurements in this paper.

A second feature of the Murrysville isopach is the relatively thick section of sandstone deposited across west-central Westmoreland County. This blocky section is most likely a stacked deltaic sequence prograding westward. The thickness ranges from 30 feet $(9 \mathrm{~m})$ to more than 140 feet $\left(43 \mathrm{~m}\right.$ ) of sand with an orientation of $\mathrm{N}^{\circ} 0^{\circ} \mathrm{W}$, and may represent braid-delta deposition. This thickened section is what originally made the Murrysville such a prolific gas reservoir, and once depleted, allowed the creation of storage fields that are still in use today. The anomalous thickness may be due to the eastern edge Rome Trough basement faults that were reactivated during Acadian tectonism. Two scenarios could be possible (1) basement faults were reactivated and the Rome Trough graben faults were slightly downthrown creating accommodation space for the Murrysville or (2) the amount of sediment coming into the Rome Trough from the uplifted eastern terrain may have created faster subsidence across this fault zone. 
Lastly, outside of the main sandstone trend, there are also some anomalously thick sandstone sections that show some uniformity, one section is north of the Blairsville-Broadtop Lineament and the other is south of the Pittsburgh-Washington Lineament. Although the outcrop at Cramer has been described as nonmarine, it is difficult to say if the Murrysville farther west is still nonmarine or transitional marine in nature. One could argue that the widespread Murrysville sands in the north and south of the lineaments may be downcurrent sands transported along the axis of the shoreline. This scenario if plausible if we accept that the Murrysville in western Westmoreland County represents braided-delta deposition. In this case, the paleoshore would be situated somewhere in west-central Westmoreland County and into west-central Indiana County. However, it is more likely that the sandstone bodies to the north and south of the main channel are abandoned delta lobes. These

sandstones have orientations perpendicular to the shoreline suggesting abandoned distributary channels. As delta building advanced throughout the Late Devonian, the main distributary as the locus of deltaic sedimentation would constantly be switching in response to slight sea-level changes, sediment supply and tectonic activity. The shoreline also coincides with the proposed Rome Trough basement fault and may have had some impact on shoreline orientation. It is clear that there is a rather dramatic drop in relative sea-level or progradation of shoreline from the Hundred Foot / Oswayo sections to the Murrysville.

\section{Riddlesburg Shale Isopach Map}

The isopach map for the Riddlesburg Shale is shown in Figure 27, and was generated by calculating the footage of shale between the top of the Murrysville sandstone and the base of the Weir sandstone. There is some variability from well to well especially in the western areas where defining the base of the Weir sandstone is difficult due to lack of key markers. A second issue is that the superjacent Weir sandstone feeder channel may have scoured into portions of the Riddlesburg Shale in the eastern part of the study area. This can be seen from the isopach map in the area of southern Indiana County where there is an unusually thin, narrow shale section.

In general, the Riddlesburg Shale ranges from 30-120 feet (9-37 m) across the study area with the thickest portion within Westmoreland County. Subsidence of the lineament-bound crustal block may have allowed for thicker shale deposition across Westmoreland County although this is 


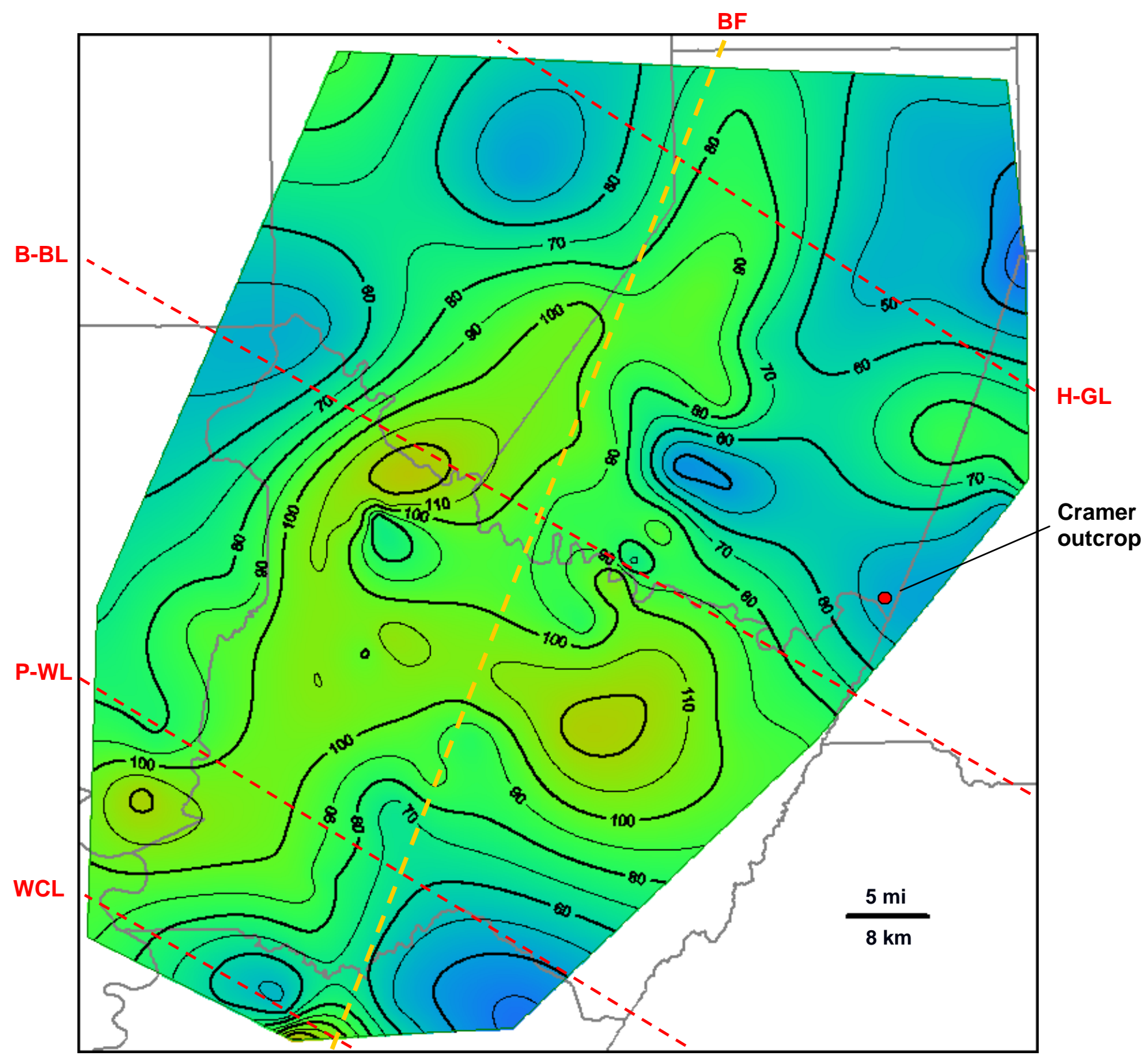

Figure 27. Isopach map of the Riddlesburg Shale. The thin shale section in southern Indiana County may show evidence that the superjacent Weir sandstone channel may have scoured into the upper portion of the Riddlesburg. Cool colors represent thin shale and warm colors represent thick shale. The contour interval is $10 \mathrm{ft}$. ( $3 \mathrm{~m}$.) 
speculative. Incised valley fill may also be a mechanism for generating the thick Riddlesburg Shale that sits above the older Murrysville channel.

\section{Weir Isopach Map}

The Weir sandstone isopach (Figure 28), in contrast to the Murrysville sandstone below it, has two noticeable trends, one $\mathrm{N} 10^{\circ} \mathrm{E}$ that ranges from Indiana County to east-central Westmoreland County and the other oriented $\mathrm{N}^{\circ} 0^{\circ} \mathrm{W}$ across southern Indiana County. The thickest Weir section occurs in southern Indiana County where net thicknesses are approximately 45 feet $(14 \mathrm{~m})$. In the northeastern portion of the study area, there are three noticeable sandstone bodies with slight breaks between them, suggesting a barrier-bar system reminiscent of the Hundred Foot sandstone. Sandstone thickness generally decreases westward across the study area with some intermittent sandstone trends in western Westmoreland County and into Allegheny. Sandstone is altogether absent in the extreme western portion of the study. The sandstones of the Weir thin abruptly just before reaching the area of the proposed Rome Trough basement fault. It is unclear if the Weir sandstone was actually influenced by Rome Trough basement faults or if deposition adjacent to the fault was coincidental. Interestingly enough however, there is a depositional change across the fault from shoreface sedimentation to what may be offshore deposits. Compared to the earlier Hundred Foot sandstone isopach where sandstones concentrated on the western side of the Rome Trough fault, here the Weir displays a thickened section on the east side of the basement fault. (Compare Figures 24 \& 28.) Although there is very little evidence for it, the differences in sedimentation between the two sandstones may have been due to changes in offset of the basement fault through time. A slightly downthrown western basement block would increase sedimentation on that side while a reversal, or a downthrown eastern block, would create a thickened section on the east side. The Acadian orogeny may have induced small movements along pre-existing basement faults to create such a scenario, either by compression and relaxation, or by differential loading of one side over the other.

Interestingly enough, the Weir sandstone feeder channel is also oriented along nearly the same path as the Murrysville channel discussed earlier, suggesting that the Weir channel may have also been influenced by the Blairsville-Broadtop Lineament. The Weir sandstone may represent either a short-term hiatus in sea-level rise, or sediment influx temporarily overcame the transgression for a short 


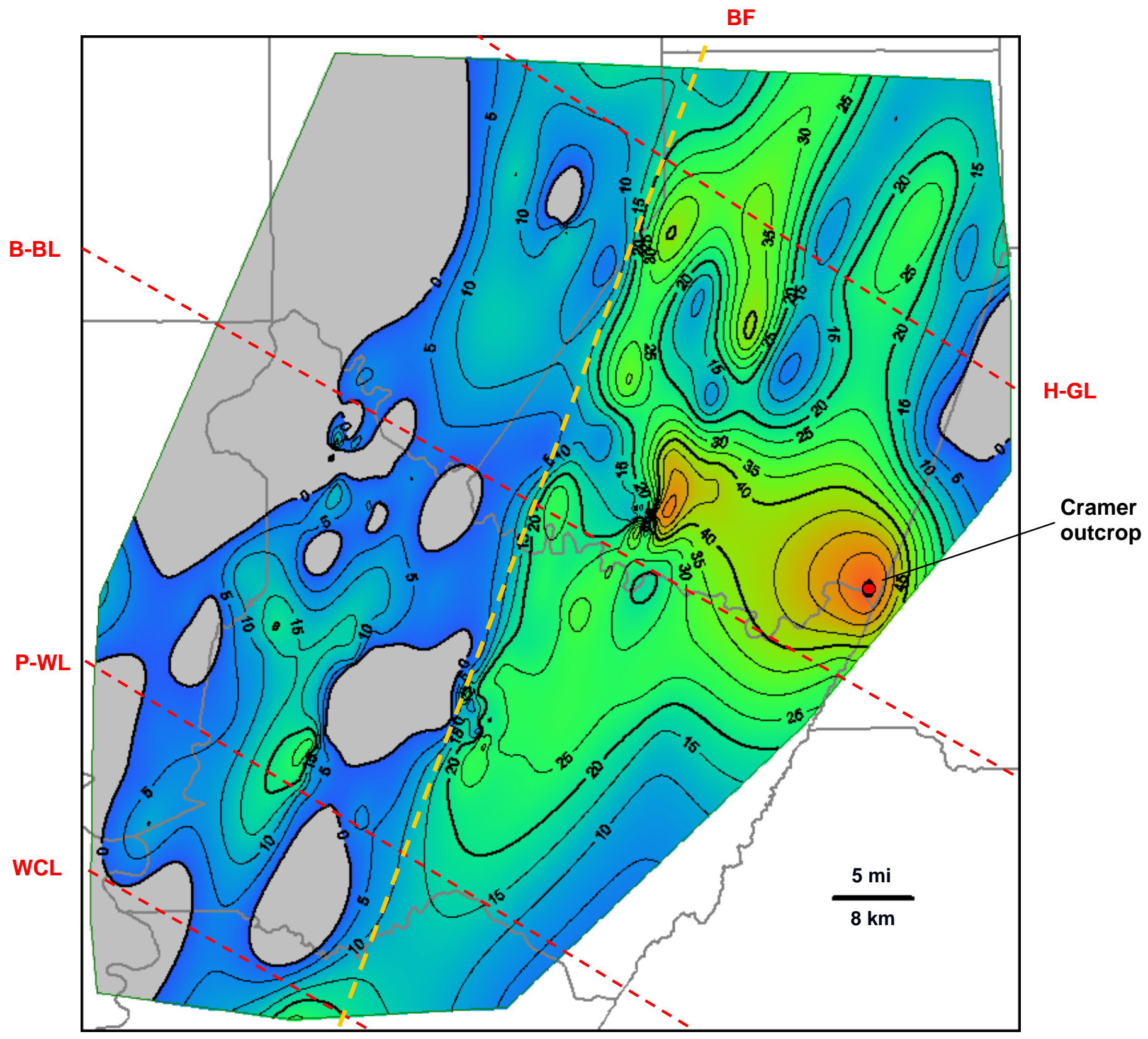

Figure 28. Isopach map of the Weir sandstone with superimposed lineaments and basement fault. Notice the abrupt thinning westward across the proposed basement fault. The thick sand section at the east of the study may have been controlled by the Blairsville-Broadtop Lineament (B-BL.) Cool colors represent thin sandstones and warm colors represent thick sandstones. The contour interval is $5 \mathrm{ft}$. $(1.5 \mathrm{~m}$. 
time. The latter may be the most plausible since there may be a potential flooding surface that occurs above the conglomerates and coarse-grained sands at the top of the Weir. The interpretation by Harper and Laughrey (1989) that the Weir sandstone represents mouth bar deposition, presumably in a marine environment dominated by fluvial output, is somewhat contradictory to the findings here. The Weir sandstone isopach map generated in this paper supports a coastal / shoreface interpretation. The isopach sandstone orientation, lateral extent, and coarsening-upward sequence observed in well-logs (Figure 18) support a prograding coastal-sand body. The sandstone is too large and in the wrong orientation for a distributary mouth bar described by Harper et al. (1989.)

Although the Weir discussed in this study is interpreted to be a coastal sand body, there may be two possible depositional environments that could be inferred from the limited data. (1) The Weir is a barrier-bar system trending northeast-southwest with a lagoon that sits to the east of the study area and coast farther east, or (2) the Weir is a coastal sandstone body, directly on the main shoreline with no lagoon behind. The latter assumes that Harper et al's. (1989) outcrop description may actually represent a fluvial system cutting into a coarsening-upward beach section, rather than the coarseningupward sequence of a distributary mouth bar. More data are needed throughout Cambria County to determine if the Weir is indeed shoreface or barrier bar in nature. 


\section{Description and Interpretation of Cross-sections}

Whereas the isopach maps were a summation of the total sand from each formation, and were useful in determining the sandstone geometry, the cross sections presented in this portion of the study allow for better resolution of the individual sandstone bodies and their migration direction within the basin. Eight sections were constructed, five strike lines and three dip lines. One of the strike lines and two of the dip lines were correlated to the outcrop at Cramer, PA. Evidence from the sections lends support to the idea that cross-structural lineaments may have controlled sediment distribution patterns as well as Rome Trough faulting.

\section{A - A' Cross Section}

Figure 29 is the section generated along the A-A' line in the easternmost portion of the study area and is comprised of five logs that were correlated from Fayette County to Indiana County and incorporated the outcrops at Cramer, PA. The Murrysville zone dominates the central portion of the cross-section as the line crosses the braided channel near Cramer. Immediately to the northeast, the Murrysville disappears completely into the adjoining interfluvial shale and siltstone. The BlairsvilleBroadtop Lineament (B-BL) may have been responsible for the facies change between the channel and interfluvial sections seen in the cross-section. The correlation from well logs 1 and 2 may represent a facies change between the minor stream sandstones versus main channel sandstones. The change in the gamma-ray log characteristics from thinning sands to blocky sands may be evidence of this change.

The Hundred Foot sandstone is nearly nonexistent in this cross-section since it is far to the east of the main barrier bar trend. The shale and siltstone with intermittent sandstones may represent tidedominated lagoonal and estuarine deposits between the barrier system to the west and the shoreline to the east. The outcrop has been interpreted to be restricted marine (Harper et al., 1989), and the lack of sand as seen from the well logs, and the sand geometry and distribution from the isopach map also support this interpretation.

The Weir sandstone is fairly well developed along this section, but there is a noticeable thinning to the northeast as the sediments cross the Blairsville-Broadtop Lineament. The Cramer outcrop may represent the feeder channel that was distributing sediments into a coastal beach system located to the 


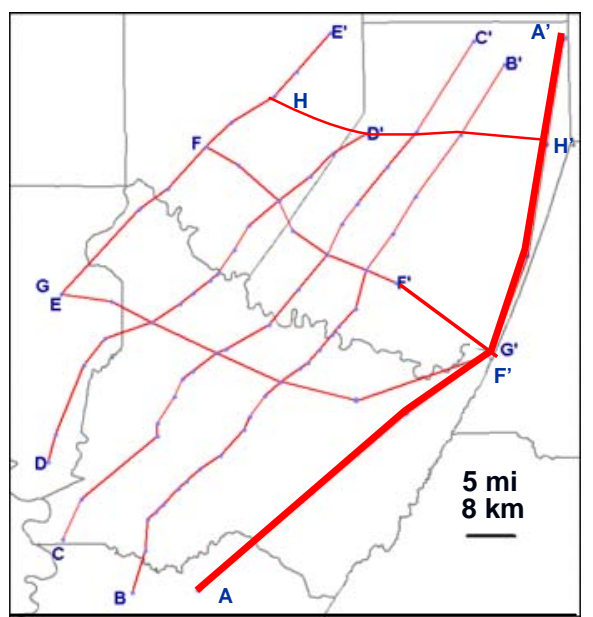

Figure 29. Cross section A-A'. The thick, blocky Murrysville channel changes abruptly into interfluvial sediments to the north as it crosses near the Blairsville-Broadtop Lineament.

Murrysville sands in the southwest are likely secondary channels and abandoned delta lobes. The Weir sandstone is best developed in the outcrop but still shows the coarsening-upward sequence in log sections. The Weir sediments are pervasive in this section since barrier bar development is strike-trending with the cross section. The Hundred Foot sandstone is almost non-existent since the majority of this interval contains lagoonal siltstones and shales. See Figure 19 for the location of each numbered well.

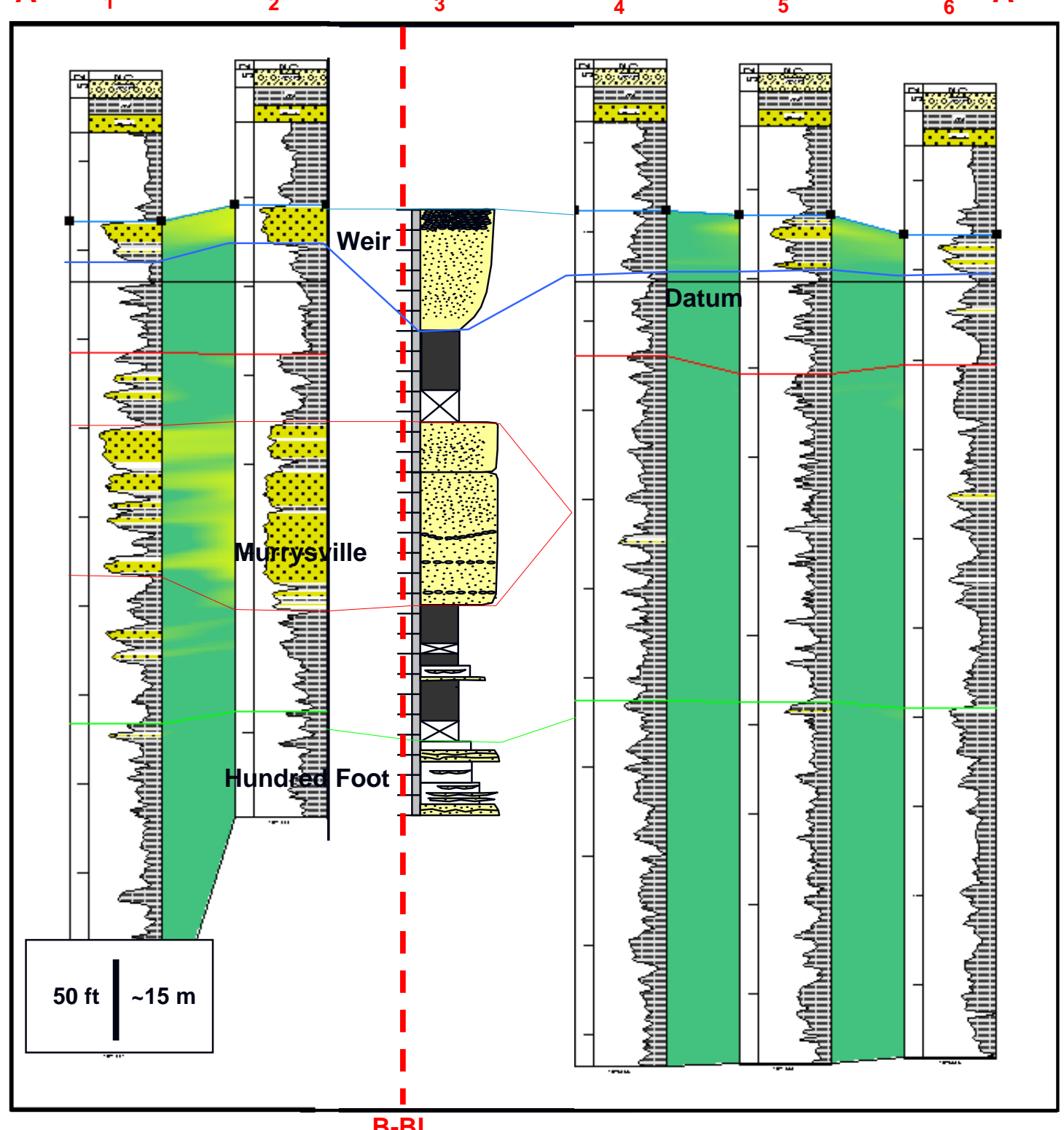

B-BL 
west. The Weir feeder channel may have also contributed to the removal of the underlying Riddlesburg Shale by scouring, as the Riddlesburg datum becomes unreliable near Cramer.

\section{B - B' Cross Section}

Figure 30 is the section generated along the B-B' line, and is comprised of 24 well logs that run from northern Fayette County into Indiana County. Figure 31 is a section zoomed in to the thick Murrysville sandstone trend at the center of the cross-section. Immediately apparent is the thick braided-stream Murrysville sequence at the center of the section that grades somewhat abruptly into thinner, more discontinuous interfluvial sandstones at its extreme northeast and southeast ends. The Home-Gallitzen Lineament (H-GL), Blairsville-Broadtop Lineament (B-BL), and the PittsburghWashington Lineament ( $\mathrm{P}-\mathrm{WL})$ have also been interpreted along this section. The lineament interpretations in the B-B' section agree with the position of the lineaments inferred from the isopach maps, as well as the positioning of the lineaments by other authors (Parrish and Lavin, 1982.) The suggestion here is that the position of the Murrysville was controlled by bounding lineaments on the north and south that kept the fluvial system entrenched between them, either by acting as barriers during lateral movement, or by dropping down the block between the lineaments in response to regional Acadian tectonics (Figure 32.) The discontinuous sandstone sections outside of the main Murrysville fluvial channel represent nonmarine interfluvial deposition.

The Hundred Foot sandstone is very intermittent along this line due to its position on the extreme eastern edge of deposition, most likely in a tidally influenced lagoon environment based on the near complete absence of sand. One could make the argument that the somewhat thick, blocky sands of the Hundred Foot that show up below the Murrysville also look as if they pinch out near the inferred lineaments, but this is debatable. The blocky sandstone characteristic along this section my represent tidal channel deposits.

The Weir sandstone in contrast displays a distinctive wedge of coarsening-upward sandstone, indicative of a mainland sand body that thins from the northeast to the southwest and terminates altogether into southern Westmoreland County and into Fayette County. From the cross sections, there is minimal evidence to suggest that the Blairsville-Broadtop Lineament somehow influenced Weir sandstone deposition although there is a definite thickening of section south of the proposed HomeGallitzen Lineament. 
B

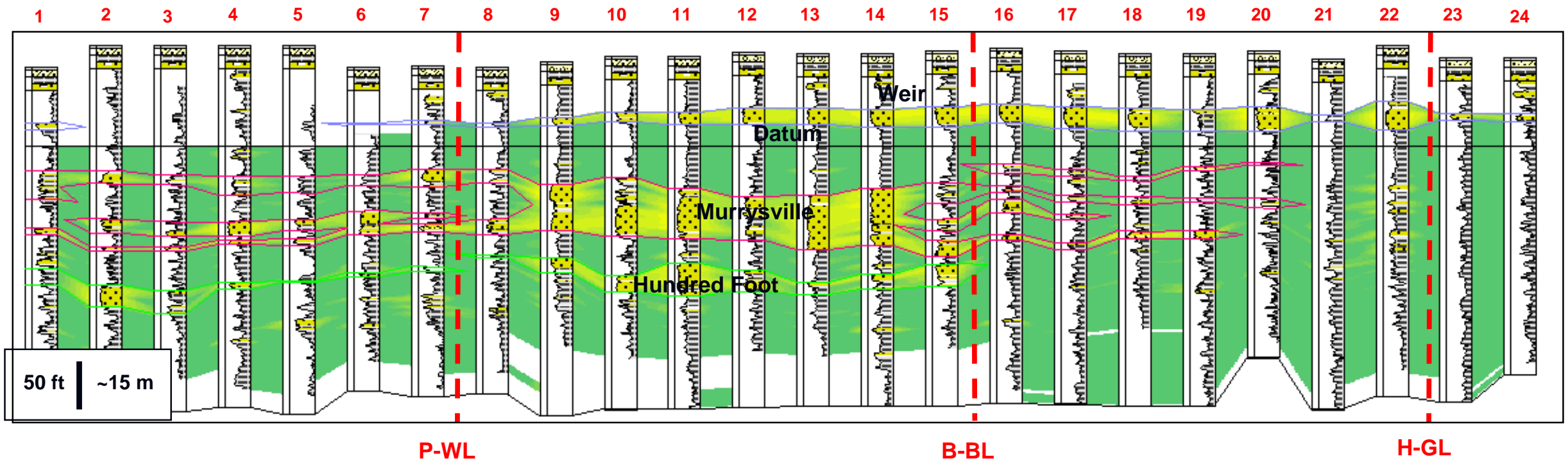

Figure 30. Cross section B-B'. The thick Murrysville across Westmoreland County grades into thinner, more discontinuous layers as it crosses the Blairsville-Broadtop Lineament (B-BL) to the north and the Pittsburgh-Washington Lineament (P-WL) to the south. The Weir shows a gradual thinning from northeast to southwest. The Hundred Foot is poorly developed in this section. See Figure 19 for the location of each numbered well.

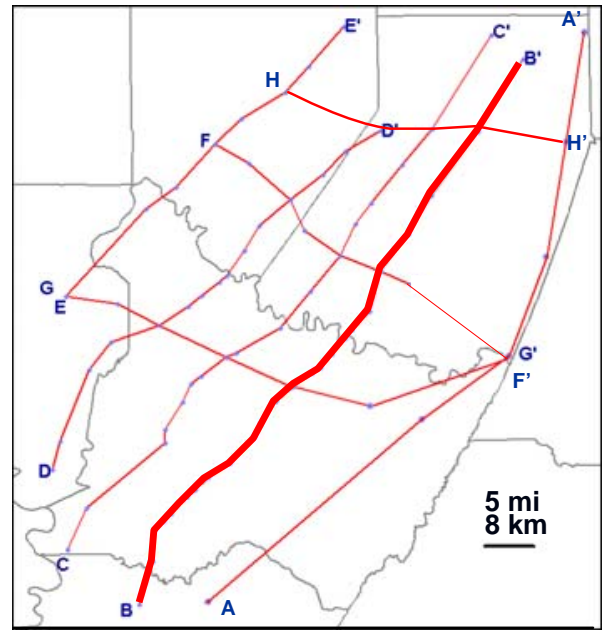


B 7 $8 \quad 9$ $10 \quad 11$

$12 \quad 13$

14

B'

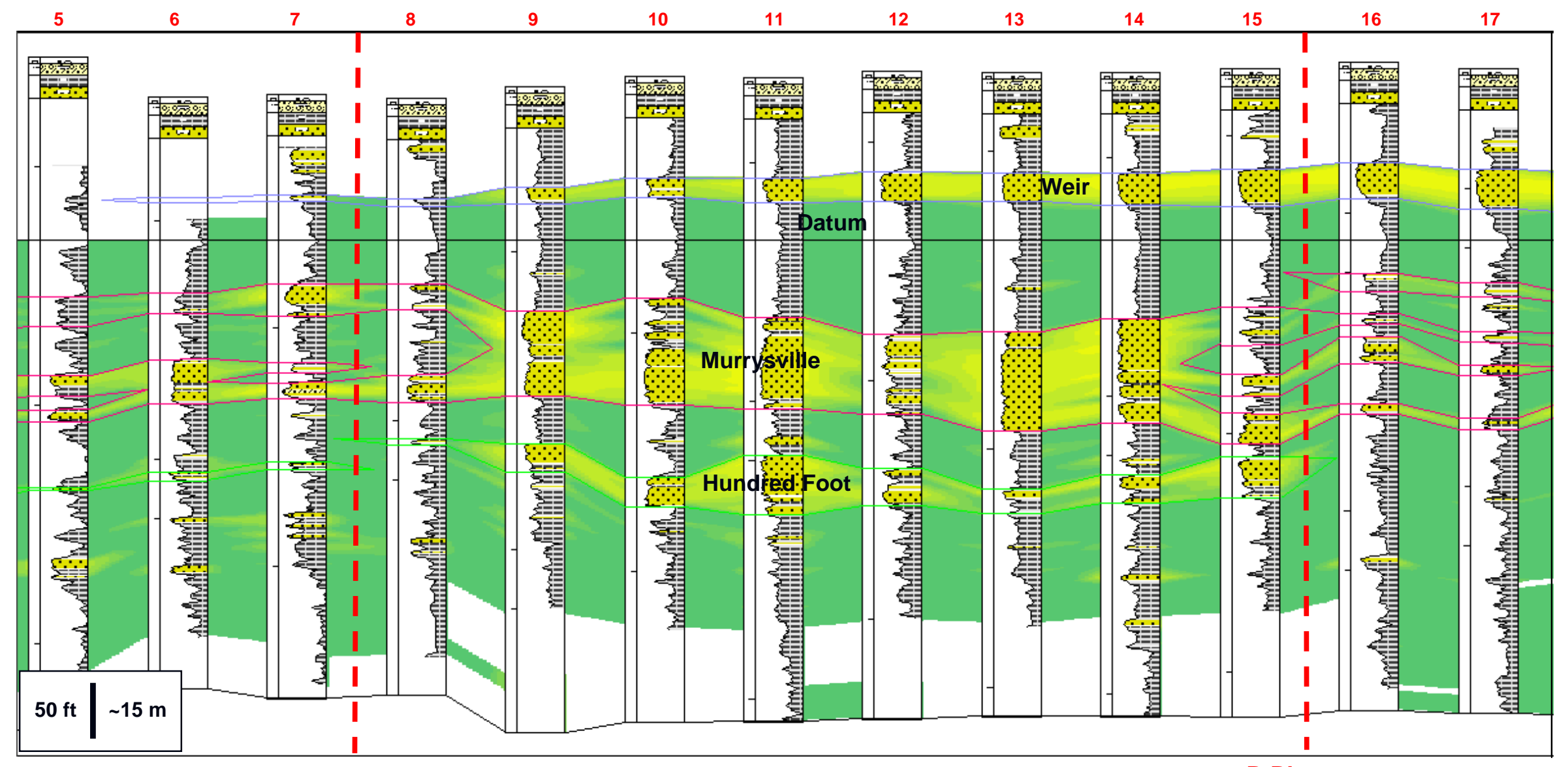

\section{P-WL}

Figure 31. Zoom section of line B-B' to show more detail. Notice the coarsening upward sequence of the Weir across much of the study area. The outcrop at Cramer shows this same coarsening upward sequence. Where the Murrysville channel exists, the log character displays a large, blocky sandstone and gradually thins to the north and south, likely as abandoned delta lobes. The Hundred Foot is intermittent but where developed shows a blocky character much like the Murrysville See Figure 19 for the location of each numbered well.

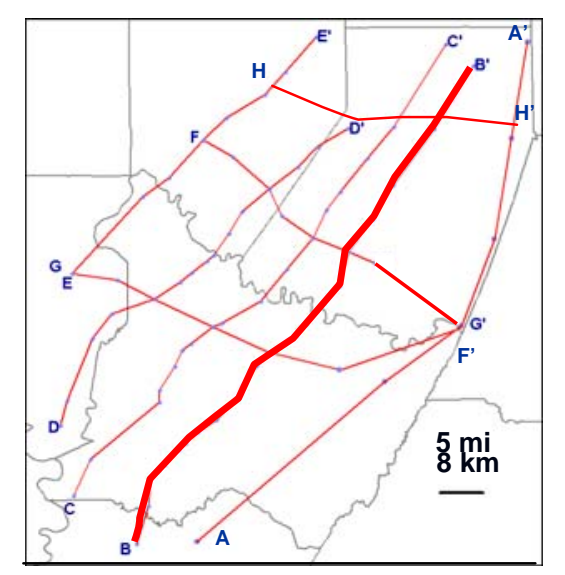




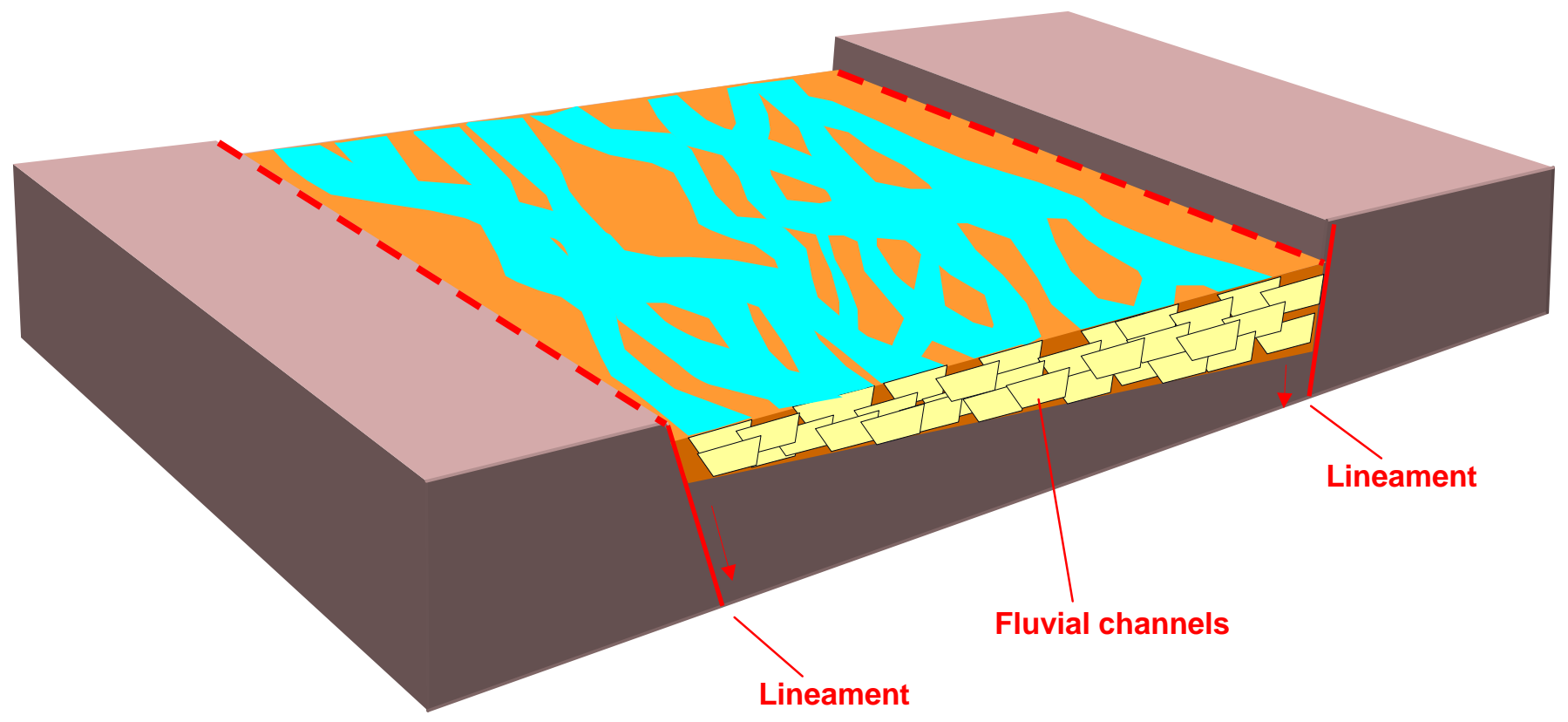

Figure 32. The working model to describe Murrysville distribution suggests that the bounding lineaments to the north and south were acting as lateral barriers during braided stream migration across the area. Acadian tectonics may have also created the mechanism to not only cause lateral movement along lineaments but also vertical movement as well. Relief of only a few feet would be enough to contain the fluvial system. 


\section{C - C' Cross-Section}

Section C-C', consisting of 17 logs as seen in Figure 33, also shows the same braided stream type Murrysville in Westmoreland County grading into thinner, more discontinuous sandstones north and south of the projected lineaments. The total sand thickness for the Murrysville is approximately 80 100 feet $(24-30 \mathrm{~m})$ which is slightly greater than in the B-B' line due to the inferred basement fault that runs between the two, especially across Westmoreland County. The thickness of the braided deposit hints at an incised valley system controlled by bounding lineament to the north and south, and by small movements of the basement. The inferred fault may have been reactivated during the Acadian orogeny allowing sediments to accumulate on the downthrown (west) portion of the fault block.

The Hundred Foot sandstone is slightly better developed here than in the B-B' line due to its position closer to the barrier-bar system and away from the lagoonal facies. Notice that the Hundred Foot pinches out in close proximity to the inferred lineaments and may hint at potential lineament control on deposition. The Weir sandstone becomes more erratic in this section due to its position near the western edge of the shoreface system but still displays a general thinning from north to south.

\section{D -D' Cross Section}

Section D-D' (Figure 34) contains 15 logs that are correlated from eastern Allegheny County, through northwestern Westmoreland County, and into southern Armstrong County. This section displays the most striking example of the thinning of the Murrysville across the Blairsville-Broadtop Lineament as well as extreme thinning across the Pittsburgh-Washington Lineament. The thick Murrysville sandstone section represents braided-delta deposition while the thin represent off-delta sedimentation. Also evident here is a second Murrysville sandstone thick that lies along the northern half of the cross-section, thought to be abandoned delta lobes adjacent to the developing delta. Sealevel fluctuations and longshore currents (and perhaps minor subsidence of the tectonic block between the Home-Gallitzen Lineament and Blairsville-Broadtop Lineament) would have influenced these delta lobes.

The Hundred Foot sandstone is best developed along this section, with thinning from south to north, and the blocky sandstone indicates that we are within the barrier system, and away from the tidally influenced lagoon. Notice that when crossing the Blairsville-Broadtop Lineament the Hundred 
C

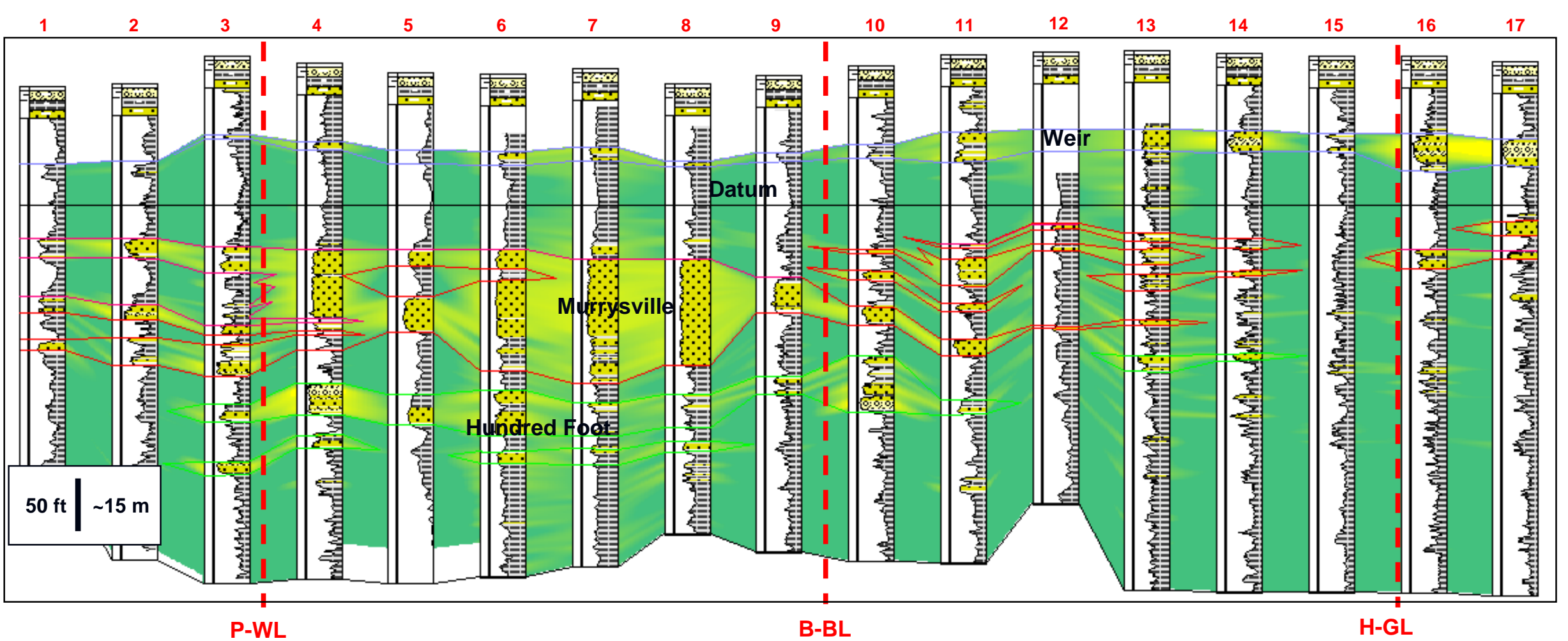

Figure 33. Cross section along C-C'. This line is similar to B-B' in that it also shows Murrysville sandstone thinning across the proposed lineaments. The Hundred Foot becomes slightly more prominent while the Weir sandstone becomes thinner and more erratic. The Murrysville sandstone also displays an unusual westward thickening than in the previous B-B' section that suggests some depositional control from the Rome Trough basement fault that is in a similar orientation as the cross-section. See Figure 19 for the location of each numbered well.

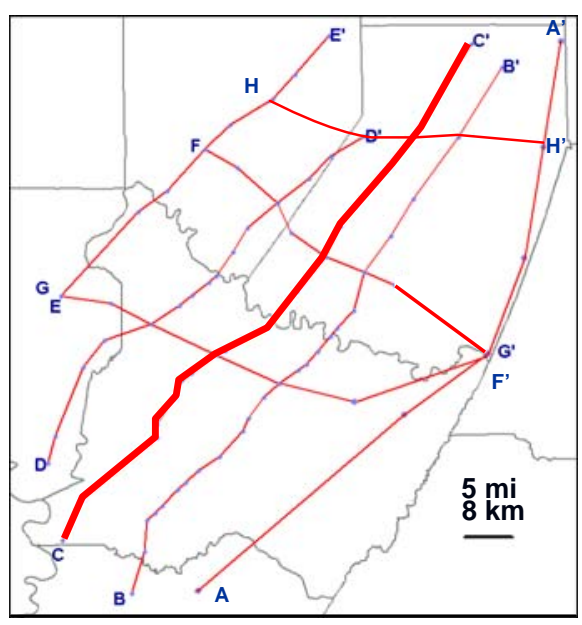


D

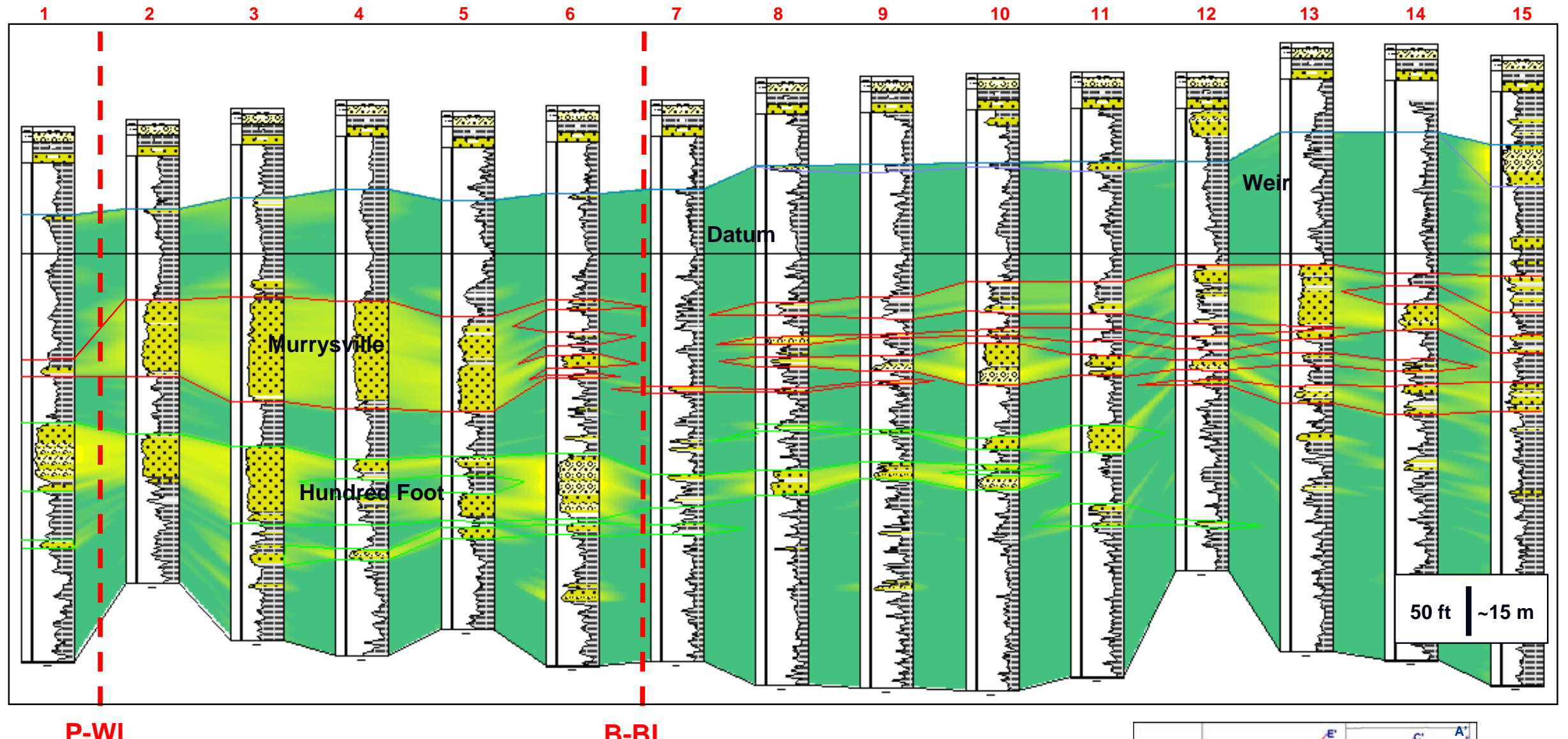

Figure 34. Cross section along D-D'. The most dramatic thinning occurs along this line as the Murrysville crosses the Blairsville-Broadtop Lineament (B-BL). Also evident is that there are two thick sequences of Murrysville, one thick and blocky in the southwest and another that lies to the northeast. It is unclear how this northeastern Murrysville relates to the blocky section to the south. One hypothesis may be that the north Murrysville may be nearshore deposits deposited north and south of the main channel the or perhaps these sandstones are abandoned delta lobes. The Weir is thin since it is far to the west of its depositional trend. The Hundred Foot becomes thick to the south, and it is here where the barrier bar sequence is best developed. See Figure 19 for the location of each numbered well.

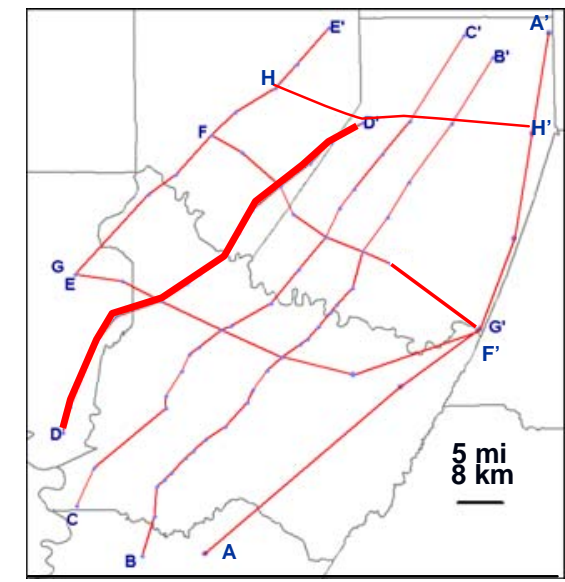


Foot goes from thick, blocky sand to a thin, more discontinuous one. This may lend some support that deposition was lineament controlled. The Weir sandstone is almost non-existent along this section due to being offshore from the coastal sequence. Sandstone in this area is thin and discontinuous and may represent small bars of shelf sandstones west of the coastal beach system. The coarsening-upward sequence seen previously in the eastern sections is altogether absent in this area.

\section{E - E' Cross Section}

The E-E' section (Figure 35) consists of 8 logs and displays the most variability among the six sections due, in part, to its position in relation to the Murrysville and Hundred Foot trends. Once again we see the Murrysville thin across the inferred Blairsville-Broadtop Lineament. The Hundred Foot also thins from south to north, and it, too, pinches out near the proposed Blairsville-Broadtop Lineament. Interestingly enough, two rather thick, blocky sections of the Hundred Foot are displayed in this line, both being separated by a siltstone and shale interval. This may represent some sort of depositional break in the barrier bar system, likely caused by moving from one barrier bar to the next as they migrate seaward. The Weir sandstone is practically non-existent in the E-E' section since it is well west of its depocenter.

\section{F - F' Cross Section}

The first of the two dip lines is shown in Figure 36. Section F-F' was drawn along a line that would purposely be "off-trend" of the main Murrysville thick to the south. Comparisons could then be made between the cross sections that are either "on-trend" or "off-trend." The section runs from western Armstrong County and across southern Indiana County to the outcrop at Cramer, PA. The Murrysville sandstones along the F-F' section are the thin, discontinuous sands that lie to the north of the main Murrysville thick section. The Rome Trough basement fault (BF) has also been included on this section to highlight some interesting depositional patterns. The cross section highlights the change from interfluvial Murrysville deposits in the east to nearshore-marine sandstones further west. First, the Murrysville sandstone displays an abrupt southeast thinning as it crosses the inferred Rome Trough basement fault. The fault in this case would be downthrown on the western side, and presumably may have created more accommodation space for sedimentation than those areas on the relatively stable eastern side of the fault. This may be the reason that there are stacked nearshore sandstones in the Murrysville on the downthrown side of the basement fault. Second, the Weir sandstone shows rapid 
thinning from east to west up to the inferred fault where it disappears altogether. The fault coincidentally marks the changeover from coastal beach Weir to emerging barrier-bar or shallow shelf Weir. Along this line of section the Weir sandstone appears to be rising to the west in relation to the datum suggesting a regressive sandstone generated during shoreface progradation. The Hundred Foot sandstone is relatively thin and discontinuous throughout this section due to the line of section crossing some of the thinner portions of the Hundred Foot isopach.

\section{G - G' Cross Section}

Section G-G' (Figure 37) is an "on-trend" dip line that runs parallel to the fluvio-deltaic Murrysville isopach trend of Figure 25 and runs from eastern Allegheny County, through Westmoreland County, and to the outcrop at Cramer, PA. This 7-log section ties the outcrop at Cramer, a sample log, and subsurface well logs across the study area. Three observations are immediately evident from this section and all are related to the Rome Trough basement fault. (1) The Hundred-Foot sandstone, in general, goes from a thick sandstone (barrier island) in the west, and gradually thins eastward until the basement fault is reached where it nearly disappears altogether (into lagoonal facies.) It also shows that the 3 main bars are stepping seaward through time (from wells four, to three to wells one and two) in relation to the datum, suggesting a westward prograding barrier-bar system. (2) The thickest portion (braid-delta) of the Murrysville sandstone along this line of section occurs just to the west of the basement fault, implying some vertical displacement either before or during Murrysville deposition, whereas the Murrysville sandstone east of the fault shows braided stream deposition. The shoreline during Murrysville time may have been controlled by basement faults. (3) The Weir sandstone thins from east to west and disappears altogether once it crosses the basement fault. As in section F-F' the Weir sandstone appears to be rising in section in relation to the datum, once again suggesting a prograding shoreface sequence.

This section provides the most striking example of possible Rome Trough fault control on each of the three sandstones studied. Although inconclusive, the G-G' section hints that during Hundred Foot and Murrysville time deposition was focused on the western side of the fault while during Weir time deposition was focused on the eastern side of the fault. The sedimentation pattern suggests differential fault movement through time although it is unclear whether this may be a relaxation phase during post- 
Acadian tectonism or perhaps tectonism was occurring later in the Devonian than previously thought (simultaneously with deposition.)

\section{H-H' Cross Section}

Section H-H' (Figure 39) is comprised of 5 logs running west-to-east in the northeastern portion of the study area. Both the Hundred Foot and Murrysville sandstones show the dramatic eastward thinning near the Rome Trough basement fault as seen in the previous sections. Although not as evident as in sections F-F' and G-G' since the easternmost two wells in the cross section (wells 4 and 5) are within the thinner sandstone areas, the Weir in section $\mathrm{H}-\mathrm{H}^{\prime}$ appears to be stepping seaward (west) in relation to the shale datum. As stated earlier, the Weir is likely a regressive sandstone generated during shoreface progradation. There may have been a minor regressive cycle during Weir time, or potentially a stillstand, that allowed the Weir to move westward across the study area before the next transgressive cycle that would shift sediments to the east and flood the developing shoreline. 
E
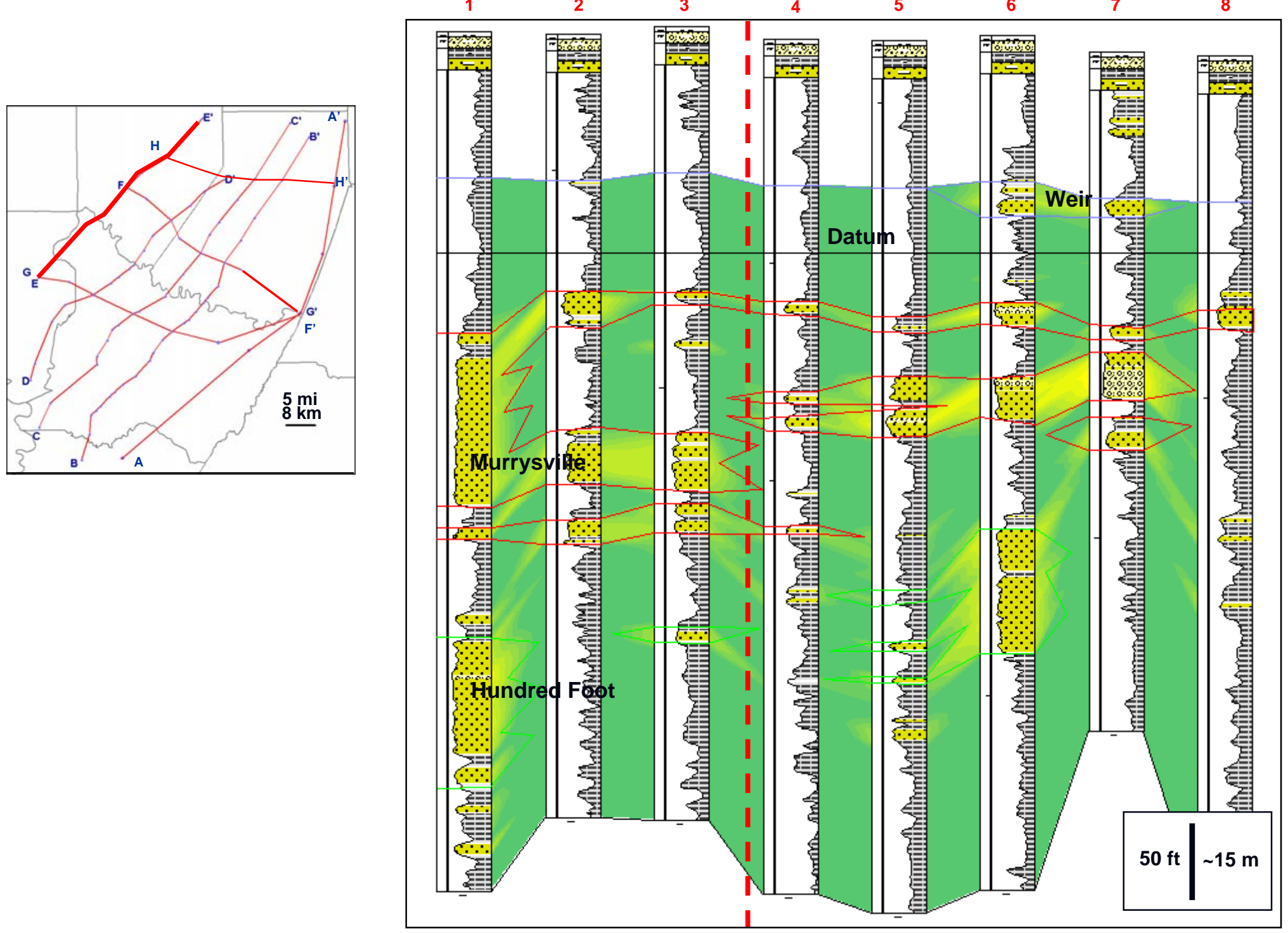

B-BL

Figure 35. Cross-section along E-E'. This is the most erratic section in terms of correlative sand units. The data becomes difficult to interpret within this section, but there is still some evidence that the Blairsville-Broadtop Lineament (B-BL) may have had some influence on deposition of the

Murrysville. The Weir sandstone is nearly gone this far west, with only a few intermittent sandstones. See Figure 19 for the location of each numbered well. 

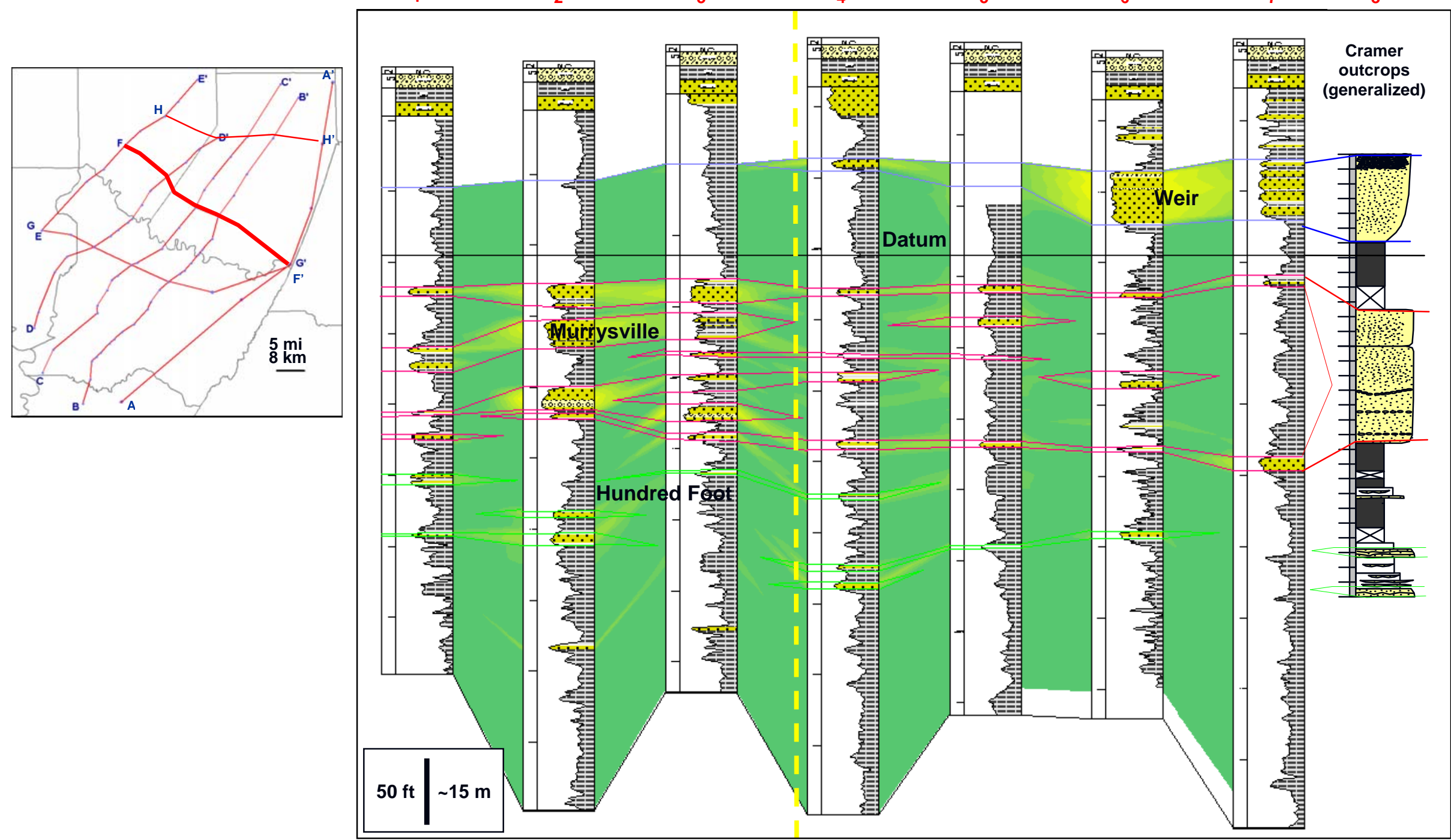

$\mathrm{BF}$

Figure 36. Cross-section along F-F'. This section was taken to show the "off-trend" or out-of-channel Murrysville. The Murrysville is developed in some areas, but is erratic with abundant shale interbeds. The Weir thickens to the east, while the Hundred Foot is almost non-existent. Notice however that there is a thickening of the Murrysville section on the northwestern side of the proposed basement fault suggesting some control on deposition. See Figure 19 for the location of each numbered well. 

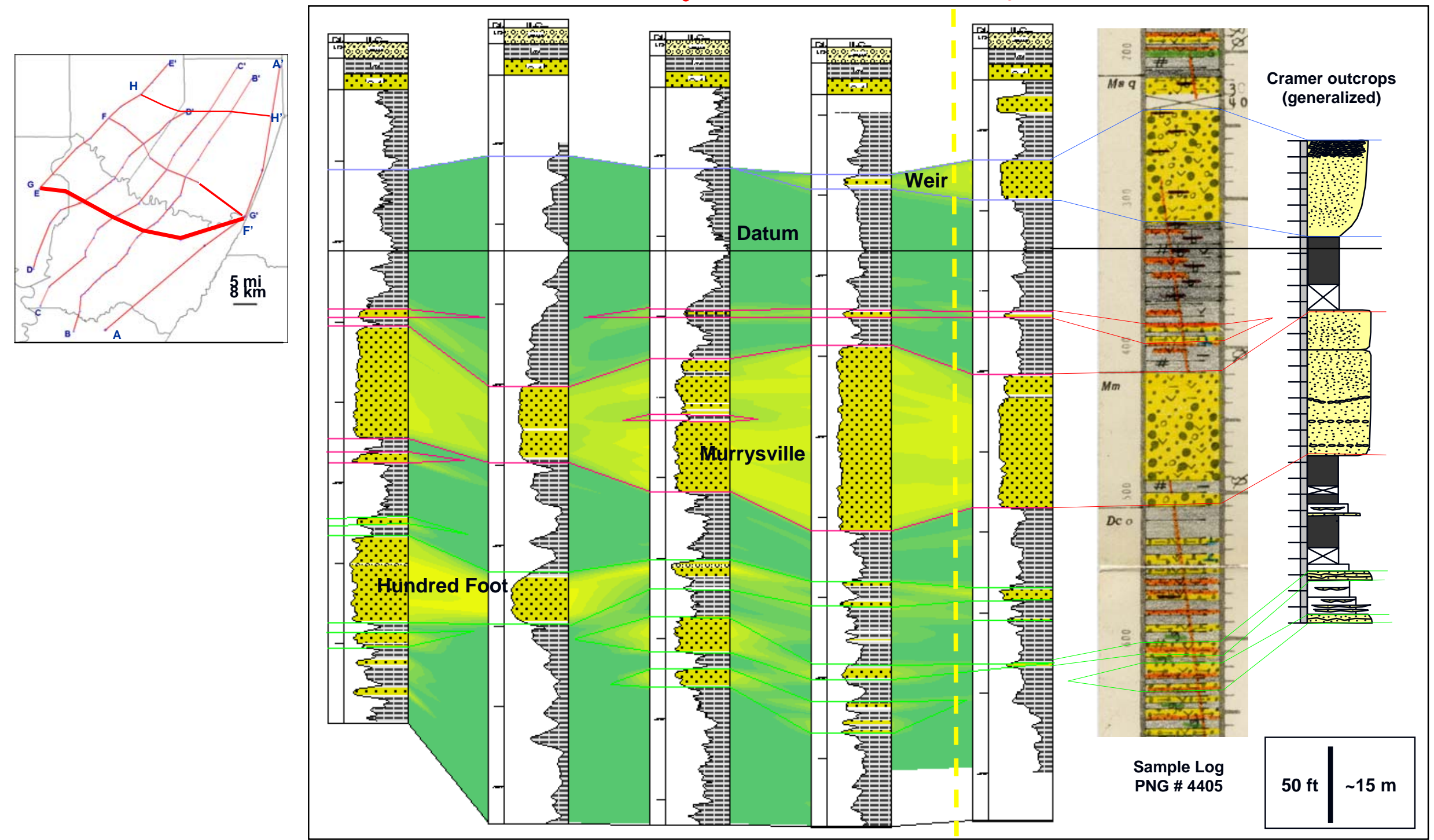

BF

Figure 37. Cross section along G-G' section. This section attempts to tie the well log section to the outcrop data along the major Murrysville trend. Three things are evident from the section. (1)The Weir dramatically thins to the west across the proposed basement fault. (2)The Murrysville displays a thickened section to the west of the basement fault. (3)The Hundred Foot thins eastward as it reaches the basement fault. See Figure 19 for the location of each numbered well. 


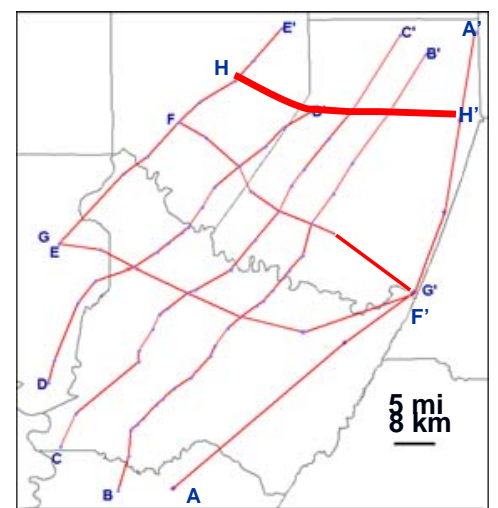

Figure 38. Cross section along section $\mathrm{H}-$ $\mathrm{H}^{\prime}$. Although not as evident as in sections F-F' and G-G', the Weir seems to rise in section in relation to the datum suggesting westward progradation of shoreline. The Hundred Foot and Murrysville sandstones show the same distinct thinning near the Rome Trough basement fault seen in previous sections. See Figure 19 for the location of each numbered well.

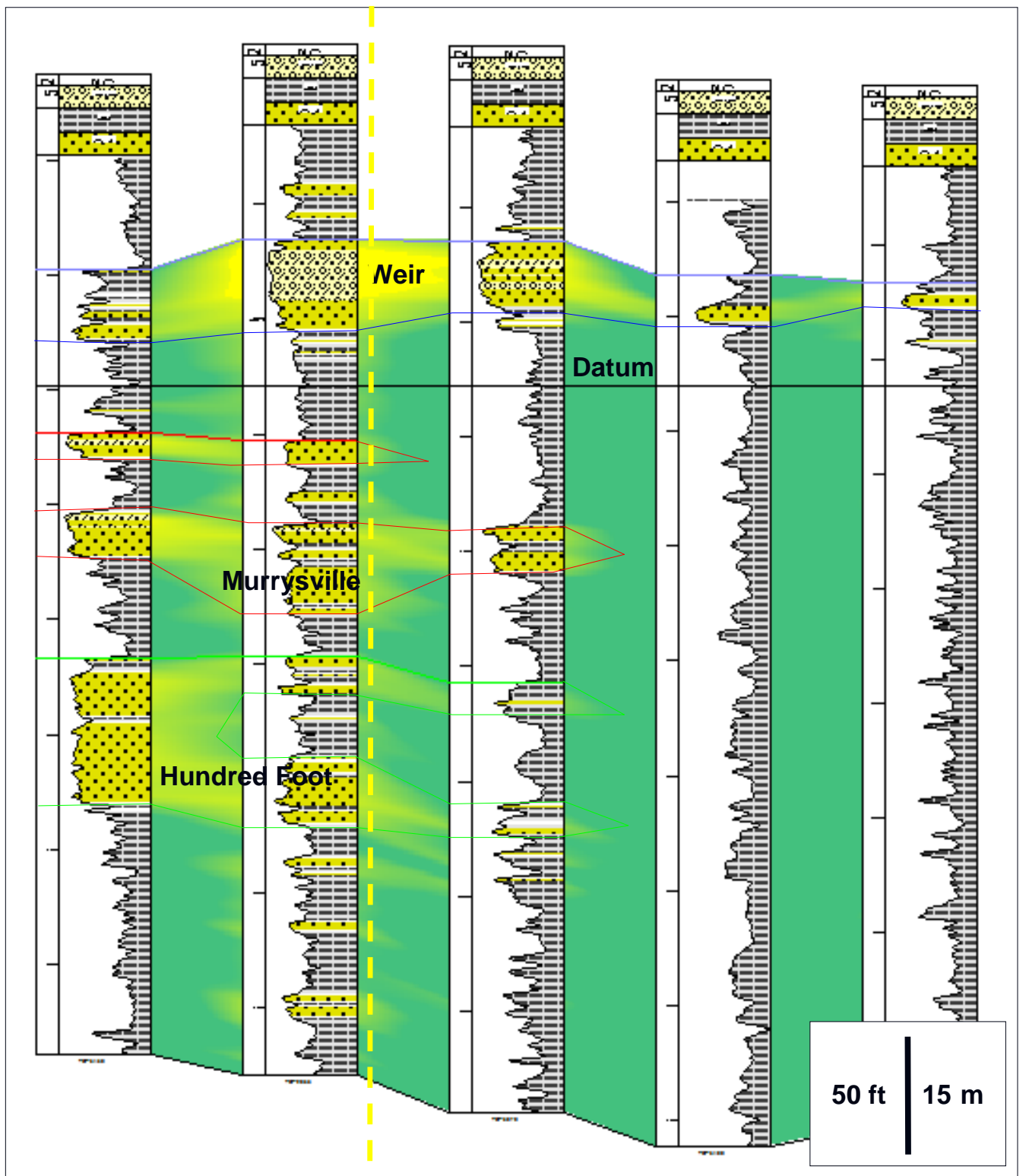

BF 


\section{Paleogeography}

\section{Hundred Foot Time}

Figure 39 is the facies distribution during Hundred Foot time. This study suggests that the Hundred Foot sandstone is a migrating barrier-bar sequence that trends nearly north-south with a tide dominated lagoon behind the barrier system. The study area shows evidence of three barrier-bars (labeled 1, 2,and 3.) As stated earlier, the western barrier-bar (3) is approximately 40 miles (64 km) in length, 5-7 miles (8-11 km) in width, and about 60 feet $(18 \mathrm{~m})$ of sand at its thickest point. The bars to the east are slightly smaller with the center bar (2) being approximately 35 miles $(56 \mathrm{~km})$ long, 5 miles $(8 \mathrm{~km})$ wide, and 80 feet $(24 \mathrm{~m})$ thick; the easternmost bar (1) is approximately 35 miles $(56 \mathrm{~km})$ in length, 5-7 miles $(8-11 \mathrm{~km})$ in width and 80 feet (24 $\mathrm{m})$ thick. The spacing between the barrier bars is approximately 5 miles ( $8 \mathrm{~km}$.) It is likely that the bars were migrating seaward through time possibly during a minor regression prior to the transgressive sequence that peaked with the deposition of the overlying Oswayo Shale. In this hypothesis, barrier-bar 1 would be the oldest and barrier-bar 3 , the youngest. The isopach mapping suggests this geometry as well as the blocky, relatively clean character of the well logs that show westward stepping bars in relation to the datum.

Also noticeable are two flood-tidal deltas deposited just to the east of barrier-bar 1 . This barrier-bar shows evidence of having been breached three times by tidal channels as sediments were washed into the lagoon behind. Both flood deltas are approximately $20-30$ feet (6-9 m) thick. Behind the barrier bar system is the tidally influenced lagoon that is dominated by shale deposition with minor amounts of sand and silt washed in by tidal and storm action. The facies change from barrier-bar and flood deltas to lagoonal facies may have been controlled by the suspected Rome Trough basement fault that runs through this area with subsidence on the western side. With the positive elevation change of the eastern portion of the fault block, any sediments moving into the area from the eastern source may have been bypassing the high eastern

block into lower areas. A second possibility is the sediments may be moving into the area by longshore drift from the north or south of the study area. The Cramer outcrop in the east displays tidal flat, shoal, tidal channel and estuarine deposition and not barrier-bar like those sequences in the western area. The position of the Hundred Foot shoreline is likely east of Cramer.

\section{Murrysville Time}

The facies distribution map for the Murrysville is shown in Figure 40. The Murrysville most likely represents fluvio-deltaic sedimentation characterized by a major braided channel (possibly in an incised- 


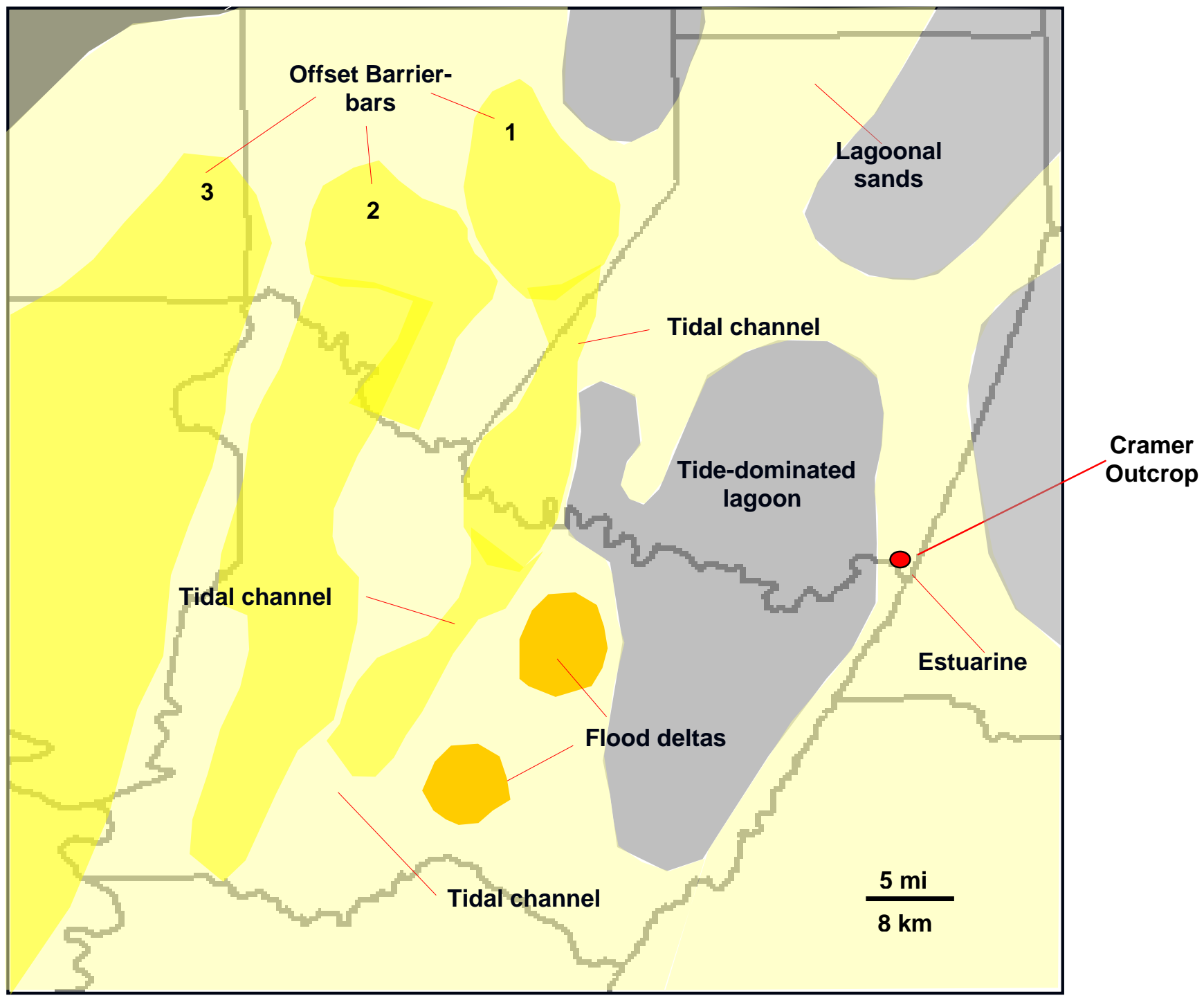

Figure 39. Paleogeography during Hundred Foot time. The Hundred Foot is thought to represent a westward migrating barrier bars $(1,2$, and 3 ) with a tidally influenced lagoon and estuarine deposits behind. Barrier bar (1) is the oldest and barrier-bar (3) is the youngest. Tidal channels and flood-tide deltas are evident from the isopach maps presented earlier. This sequence thought to represent a regressive or stillstand system with shoreline to the east. A post Hundred Foot sea-level rise would eventually flood the shelf and allow deposition of the superjacent Oswayo Shale. 


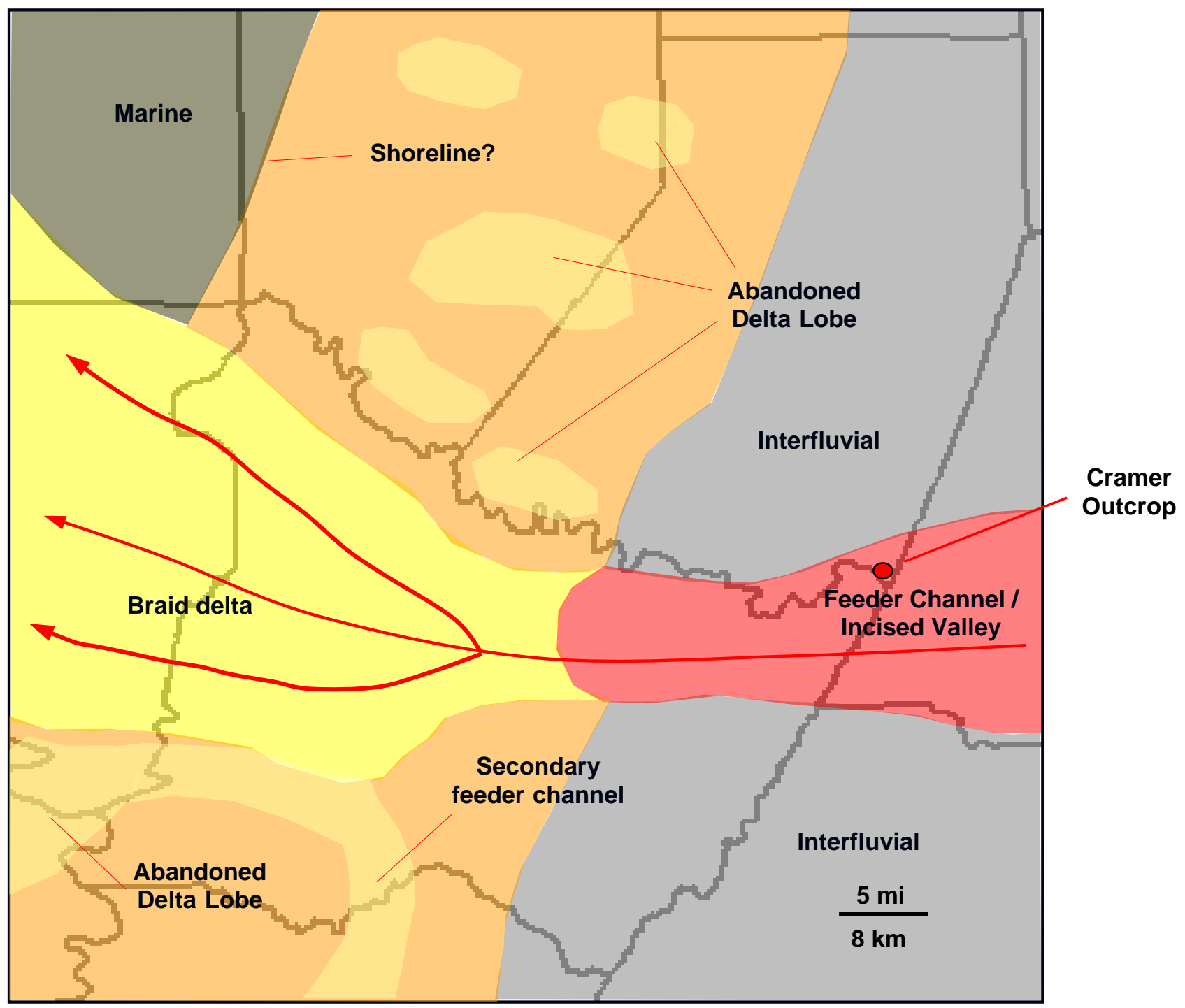

Figure 40. Paleogeography during Murrysville time. The distribution is dramatically different than earlier Hundred Foot paleogeography. The Murrysville is thought to represent a westward flowing fluvial channel forming a braid-delta at its mouth. Sandstone deposition outside of the main delta are likely abandoned delta lobes cutoff during delta switching. A secondary feeder stream may also be entering the main delta from the south. This sequence is a regressive system with shoreline migrating westward. Late Devonian glaciation may have played a role in dropping sea-level and shifting the shoreline back to the west. A flooding surface likely exists above the Murrysville as a transgression flooded the delta and allowed deposition of the Riddlesburg Shale. 
valley) flowing in an east-to-west direction and terminating in a braid-delta. Pepper et al. (1954) and Pashin and Ettensohn (1995) suggested a similar depositional scenario for the Berea / Cussewago in western Pennsylvania. The Murrysville depositional pattern is radically different that that of the Hundred Foot section and suggests a relative sea level fall that caused movement of shoreline to the west. South American glaciation during the Late Devonian (Isaacson, 1999; Sandberg et al., 2002) may have played a role through eustatic fluctuations of sea level with base level in Pennsylvania dropping enough to allow the formation of Murrysville fluvial channels. Figure 41 is a generalized sea-level curve for Pennsylvania from the Frasnian Stage to the Tournaisian Stage that shows a marked sea-level fall during Berea/Cussewago time.

The main fluvial channel has a dominantly $\mathrm{N} 90^{\circ} \mathrm{W}$ direction and is approximately 5-10 miles (8-16 $\mathrm{km})$ in width and may contain up to 100 feet $(30 \mathrm{~m})$ of sandstone. The width and depth of the channel suggests that the Murrysville in eastern Westmoreland County may be an incised-valley system whose position may have been influenced by the Blairsville-Broadtop Lineament to the north and PittsburghWashington Lineament to the south. The channel and delta complex may also have incised into the underlying Oswayo Shale as seen from the unusually thin Oswayo Shale section in northern Westmoreland County and southern Indiana County (Figure 25.) At the mouth of the channel system in west-central Westmoreland County, a braid delta was forming and began prograding seaward in a $\mathrm{N}^{\circ} 0^{\circ} \mathrm{W}$ orientation. The change from channel sequence to braid-delta in Westmoreland County may hint at a facies change generated by the Rome Trough basement fault that runs through this area. The width of the delta was approximately 20 miles $(32 \mathrm{~km})$ and at least 25 miles $(40 \mathrm{~km})$ in length as it moved out of the study area. Notice that the delta has several long fingers of sandstone, likely distributary channels, that extend seaward suggesting a fluvial-dominated delta. These fingers may contain up to 140 feet $(42 \mathrm{~m})$ of sandstone. Not surprisingly, the Murrysville has been a prolific natural gas producer from the braid-delta sand in this area.

In addition to the main channel and braid delta, there are a number of other depositional features that can be inferred from the data. Interfluvial deposits occur on either side of the fluvial channel, especially in the eastern portion of the study. In general, there is very little sandstone deposition in these areas and the unit consists mainly of shale. In the southern portion of the study area, in northern Fayette County, there may be evidence of an abandoned feeder stream and associated delta entering the study area from the south. There is a noticeable $50-60$ foot (15-18 m) sandstone running in a north-south direction and turns west with a width of approximately 3 miles $(5 \mathrm{~km})$. 


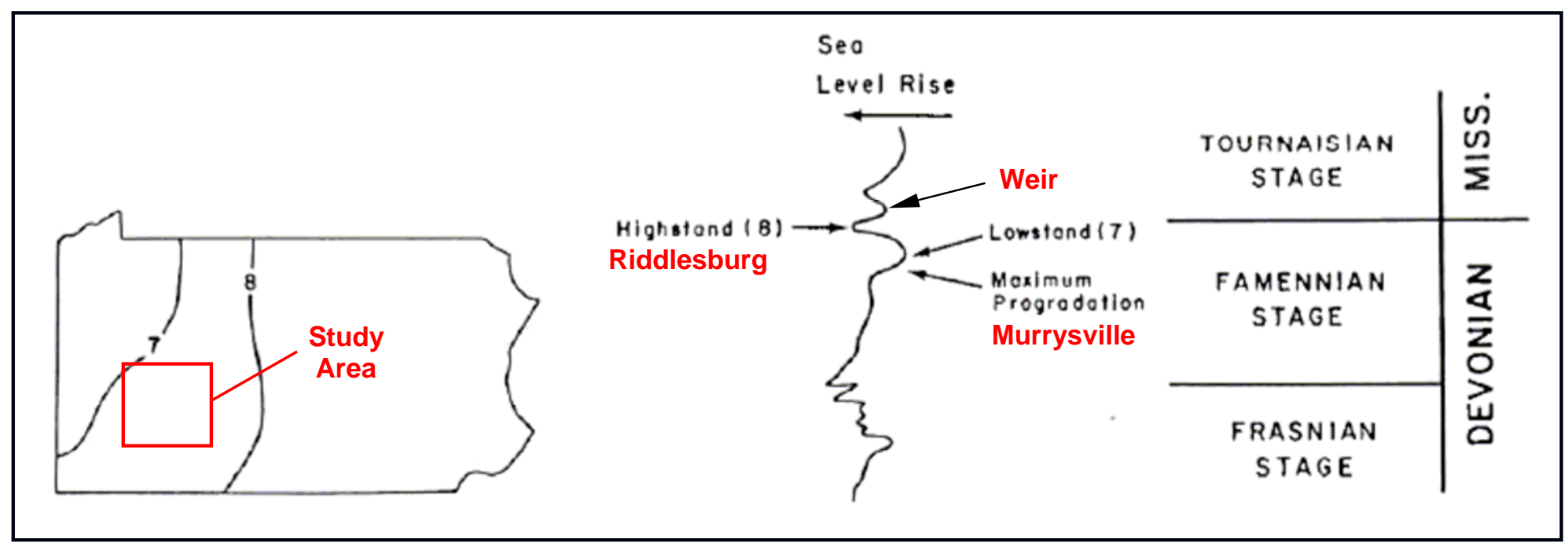

Figure 41. Sea-level curve and shoreline position during the Upper Famennian and Lower Tournaisian in western Pennsylvania. The data suggests a rapid sea-level fall during the Late Famennian (7) that lead to Murrysville incision and delta building. The highstand (8) flooded the shelf and Murrysville delta and lead to the deposition of the marine Riddlesburg Shale (from Dennison, 1985.) 
Lastly, there are a number of thick sandstones that occur to the north and south of the main braid delta system. While longshore currents moving sediments along the shoreline may have generated these sandstones, it is more likely that these bodies represent abandoned delta lobes as the distributaries became stranded during delta switching. In fact, some of the larger sand bodies, especially in Armstrong County, look similar to the seaward extending fingers of sandstone in the main channel, suggesting that these may indeed be abandoned delta lobes.

\section{Weir Time}

Figure 42 is the facies distribution during Weir time across the study area. Compared to Murrysville time there is a rather abrupt rise in sea level during this period that led to the deposition of the Riddlesburg Shale and later, the Weir sandstone. Log and isopach data as well as information from the Cramer outcrop suggest a northeast-southwest trending deposition along a coastal shoreline that had shifted eastward from Murrysville time.

A major feeder channel enters from the east of the study area and is approximately 5 miles (8 $\mathrm{km})$

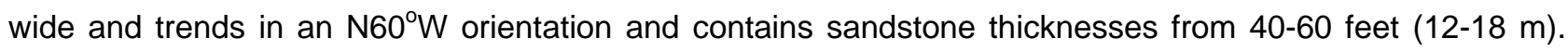
The isopach map of the Riddlesburg Shale (Figure 27) suggests that the Weir channel may have scoured 30-40 feet (9-12 $\mathrm{m})$ into the underlying shale as seen in the anomalously thin section of Riddlesburg in southern Indiana County. Interestingly, the position of the Weir feeder channel lies in nearly the same position and orientation as the older Murrysville feeder channel, suggesting that a structural element may be leading to similar stream development through time. The Blairsville-Broadtop Lineament may be a controlling factor for the development of these channels.

The coastal sandstone that trends $\mathrm{N} 30^{\circ} \mathrm{E}$ (perpendicular to the orientation of the channel) runs across the entire study area from north to south and contains from 10-35 feet (3-10 m) of sandstone. On the south side of the channel there appears to only be one large, elongate sandstone body, while north of the channel the sandstones look to split into a twin barrier bar complex. It is possible that the twin sandstone bodies in the north may not be barrier-bars, but perhaps a prograding shoreface. Interestingly, the relatively thick shoreface sandstone dramatically thins near the proposed Rome Trough basement fault, hinting that deep-seated structure may be influencing sediment deposition. Interestingly, Weir deposition is concentrated on the eastern side of the basement fault, when just the opposite was seen in the older 


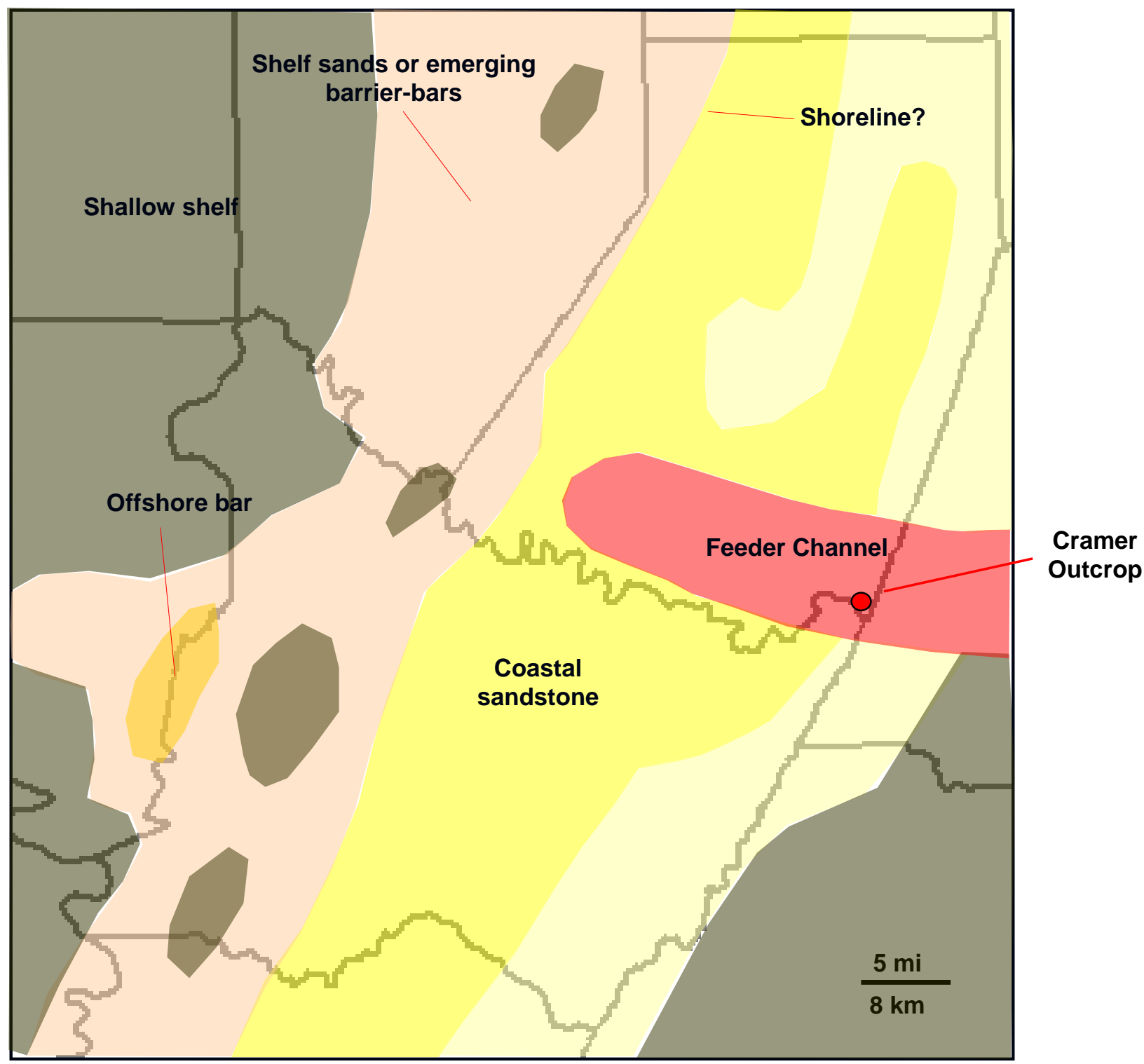

Figure 42. Paleogeography during Weir time. A post-Murrysville transgression has shifted the shoreline to the east. A westward flowing feeder channel was thought to be dispersing sediments along a coastal shoreline. These coastal sandstones may represent either a short hiatus in sea-level rise or that sediment supply was high enough to outpace the transgression. It is important to note that data in the southeast of the study area is sparse, and it has been interpreted here as an onshore coastal deposit. It is possible that what is interpreted as a coastal deposit may also be interpreted as a barrier-bar system if lagoonal deposits can be shown in the southeast. 
Hundred Foot. Although unclear from this data, there may have been some reversed tectonic conditions between deposition of the Hundred Foot and deposition of the Weir, perhaps as reverse movement on faults if collisional tectonism was still active, or as a relaxation phase along fault boundaries in response to postAcadian quiescent conditions.

Offshore to the west there appears to be a small bar in western Westmoreland County. This bar, surrounded by marine shale, is approximately 4-6 miles $(6-10 \mathrm{~km})$ wide, 20 miles $(32 \mathrm{~km})$ in length and contains $10-20$ feet (3-6 m) of sandstone. The offshore bar follows a similar orientation as the shoreface to the east. The thin, intermittent sandstones surrounding the barrier-bar and adjacent to the shoreface may be tidally influenced shelf sands or emerging bars.

It is hypothesized here that the Weir sandstone was a prograding beach complex fed and cut by a fluvial channel. Harper et al's. (1989) lower Weir section may be foreshore-shoreface sediments overlain by a channel conglomerate, rather than a prograding mouth bar sequence. It must be pointed out here that the sparse data in the southeastern section of the study may be biasing the interpretation in favor of a mainland beach. A shale sequence behind the elongate sandstone trend may show that the Weir could actually be a large barrier-bar system with a lagoon behind it, although the large fluvial channel may rule this scenario out. 


\section{Conclusions}

The Upper Devonian-Lower Mississippian depositional sequence in southwestern Pennsylvania was controlled by structural features, both cross-structural lineaments, and deep seated Rome Trough basement faulting, and by sea-level changes within the developing foreland basin. The lowermost unit of study, the Hundred Foot sandstone, constituted a barrier-bar system that was prograding westward across a shallow shelf during the Late Devonian. A short transgression inundated the barrier bar system and allowed the deposition of the Riceville Shale/Oswayo Shale across the study area and effectively ended the development of the Catskill Delta Complex. Rome Trough basement faulting is believed to have exerted some control on deposition, namely shoaling of sands, as the Hundred Foot shows an abrupt facies change from barrier-bar sandstone in the western half of the study to lagoonal and estuarine shales and sandstones in the east. The lack of sandstone in the eastern portion of the study, closer to the source area, suggests that sediments may have been bypassing the eastern shelf due to being structurally higher than in the western portion of the study area. There may also be the possibility that sediments were moving into the area by means of longshore currents carrying sediments into the area from the south.

At the beginning of Murrysville time, a pronounced regression dropped sea level and allowed the progradation of braided fluvial sediments across the newly emerged shelf. The Acadian orogeny and its associated collisional pulses provided the needed structural relief in eastern Pennsylvania to shed clastic sediments westward into the basin. The Blairsville-Broadtop Lineament and the Pittsburgh-Washington Lineament controlled drainage of the braided stream and deltas system on the north and south, respectively. The Murrysville also shows a marked thickening of section on the western side of the proposed Rome Trough basement fault suggesting that basement structures may have influenced deposition throughout Murrysville time. Progradation ended with another transgression that drowned the fluvial / delta system and forced the shoreline to the east, and allowed deposition of the marine Riddlesburg Shale.

The Weir sandstone, the youngest unit in this study, witnessed the re-emergence of sediments into the eastern portion of the study area with the formation of coastal shoreface sediments with an associated bar sandstones. The data presented here suggests that the Weir is located on the main shoreline rather

than a barrier-bar system. However, if lagoonal shale can be found in the southwestern portion of the study, this may lean the interpretation more toward a barrier-bar environment. It is likely that the prograding regressive shoreface may have been structurally influenced by the Blairsville-Broadtop Lineament, similar to 
the older Murrysville, as a Weir feeder channel exists along the lineament axis. The Weir sandstone also shows a sandstone shoaling effect to the east of the proposed Rome Trough basement fault suggesting tectonic influence on deposition. In contrast to the Hundred Foot that has its thickest sands on the western side of the basement fault, the differences in sedimentation on opposite sides of the fault may hint at fault reactivation or reversal between the two depositional events.

More work is necessary to fully evaluate the depositional systems discussed in this paper. Additional correlations into Somerset, Fayette, and Cambria County would further highlight depositional trends in southwestern Pennsylvania, and the availability of full core data that could be tied to well logs would be a huge benefit in deciphering depositional environments. There is also some confusion on how similar outcrops in West Virginia relate to their counterparts in Pennsylvania. The author believes that structural controls, especially the Pittsburgh-Washington Lineament, may have exerted greater control on depositional systems between the two states than previously thought. Lastly, since the fluvial/deltaic Murrysville seems to be restricted to southwestern Pennsylvania and occurs as the first sandstone below the Riddlesburg Shale, there may be the possibility that correlations in West Virginia presume that this first occurrence of sand below the Riddlesburg Shale must be the Murrysville. The first sand below the Riddlesburg Shale in West Virginia may actually be the Hundred Foot equivalent. 


\section{References}

Bjerstedt, T.W. and T.W. Kammer, 1988. Genetic stratigraphy and depositional systems of the Upper Devonian-Lower Mississippian Price-Rockwell Deltaic complex in the central Appalachians, U.S.A. Sedimentary Geology, v. 54, p. 265-301.

Bayles, R.E., 1949. Subsurface Upper Devonian sections in southwestern Pennsylvania. AAPG Bulletin, v 33, no. 10, p. 1682-1703.

Beardsley, R.W., R.C. Campbell, and M.A. Shaw, 1999. Part III, Chapter 20, Appalachian Plateaus, in The Geology of Pennsylvania, C.H. Shultz, ed. Pennsylvania Geological Survey and Pittsburgh Geological Society Special Publication 1, p. 286-297.

Boswell, R., L.R. Heim, G.R. Wrightstone, and A. Donaldson, 1996. Play Dvs: Upper Devonian Venango sandstones and siltstones, in The Atlas of Major Appalachian Gas Plays. J.B. Roen and B.J. Walker, eds. West Virginia Geological and Economic Survey, Pub. V-25, p. 63-76.

Boswell, R. 1985. Stratigraphy and sedimentation of the Acadian Clastic Wedge in Northern West Virginia. M.S. Thesis, West Virginia University., Morgantown, WV, $179 \mathrm{pp}$.

Butts, C. and F. Leverett, 1904. Kittanning folio, Pennsylvania. U.S. Geological Survey, Bulletin 52, Part 1, 568 p.

Butts, C., 1908. Pre-Pennsylvanian stratigraphy. Pennsylvania Geological Survey, $3^{\text {rd }}$ series, Report of 1906-1908, p. 190-264.

Cant, D.J., 1982. Fluvial facies models and their application, in Sandstone Depositional Environments. P.A Scholle and D. Spearing eds. AAPG Memoir 31, p. 115-137.

Carter, J.L. and T.W. Kammer, 1988. Late Devonian and Early Carboniferous brachiopods (Brachiopoda, Articulata) from the Price Formation of West Virginia and adjacent areas of Pennsylvania and Maryland. Annals of Carnegie Museum, v. 59 , no. 2 , p. $77-103$.

Castle, J.W. 2001. Foreland-basin sequence response to collisional tectonism. GSA Bulletin, v. 113, no. 7, p. 801-812.

Dennison, J.M., 1970. Stratigraphic divisions of the Upper Devonian Greenland Gap Group ("Chemung Formation") along Allegheny Front in West Virginia, Maryland, and Highland County, Virginia. Southeastern Geology, v.12, no. 1, p. 53-82.

--- 1985. Catskill Delta shallow marine strata, in The Catskill Delta. D.L. Woodrow and W.D. Sevon eds. GSA Special Paper 201, p. 91-105.

de Witt, W., Jr. 1946. The stratigraphic relationship of the Berea, Corry, and Cussewago sandstones in northeastern Ohio and northwestern Pennsylvania. U.S. Geological Survey Oil and Gas Investigations, Preliminary Chart 21.

--- 1970. Age of the Bedford Shale, Berea Sandstone, and Sunbury Shale in the Appalachian and Michigan Basins, Pennsylvania, Ohio, and Michigan. U.S. Geological Survey Bulletin 1924-G, 11p. 
Dolezal, 2004. Depositional environments and sequence stratigraphy of the Rockwell- Price Formation in Western Maryland, South-Central Pennsylvania, and Northern West M.S. Thesis, West Virginia University, Morgantown, WV, 116 pp.

Ettensohn, F.R. 1994. Tectonic control of formation and cyclicity of major Appalachian unconformities and associated stratigraphic sequences, in Tectonic and Eustatic Controls on Sedimentary Cycles, J.M. Dennison and F.R. Ettensohn, eds., p. 217-242.

Faill, R.T., 1985. The Acadian orogeny and the Catskill Delta, in The Catskill Delta, D.L. Woodrow and W.D. Sevon eds. GSA Special Paper 201, p. 15-37.

Fettke, C.R. and R.E. Bayles, 1945. Conemaugh Gorge section of the Mississippian System southeast of Cramer, Pennsylvania. Proceedings of the Pennsylvania Academy of Science, v. 19, p. 86-95.

Feldmann, R.M., J.T. Hannibal, and D.J. Mullett, 1992. The paleoecology of Echinocaris randallii Beecher from Drake well, Titusville, Pennsylvania, in Proceedings of the F.D. Holland, Jr., Geological Symposium, J.M. Erickson, ed. North Dakota Geological Survey Miscellaneous Series, No. 76, p. 137-147.

Flaherty, K. J., 1996. Play Dho: Fractured Middle Devonian Huntersville Chert and Lower Devonian Oriskany Sandstone, in The Atlas of Major Appalachian Gas Plays. J.B. Roen and B.J. Walker, eds. West Virginia Geological and Economic Survey, Pub. V-25, p. 103-108.

Gao, D., R.C. Shumaker, and T.H. Wilson, 2000. Along-axis segmentation and growth history of the Rome Trough in the Central Appalachian Basin. AAPG Bulletin, v. 84, p. 75-99.

Gold, D.P., S.S. Alexander, R. Cakir, A.G. Doden and S.I. Root, 2005. Precambrian basement map of the Appalachian basin and Piedmont province in Pennsylvania. Pennsylvania Geological Survey, Portion of Open-File General Geology (OFGG) Report OFGG 05-01.0.

Harper, J.A, D.B. Tatlock and R.T. Wolfe, Jr., 1999. Petroleum, shallow oil and natural gas, in The Geology of Pennsylvania. C.H. Shultz ed. Pennsylvania Geological Survey and Pittsburgh Geological Society Special Paper 1, p. 484-505.

Harper, J.A. and C.D. Laughrey, 1987, Geology of the oil and gas fields of southwestern Pennsylvania, Pennsylvania Bureau of Topographic and Geologic Survey, Mineral Resources Rep. M87, 166 p.

--- 1989. Upper Devonian and Lower Mississippian stratigraphy and depositional systems, in Geology in the Laurel Highlands of Southwestern Pennsylvania, J.A. Harper ed., $54^{\text {th }}$ Annual Field Conference of Pennsylvania Geologists Guidebook, Oct. 5,6, and 7, 1989, p. 191-202.

Hughes, H.H., 1933. Freeport quadrangle-geology and mineral resources. Pennsylvania Bureau of Topographic and Economic Survey, Fourth Series, Atlas A 36, 272 p.

Hussing, R.B., 1994. Structure and sedimentation of Upper Devonian Bradford Group "Kane" Sandstone of Cush Cushion Field, West-Central Pennsylvania. M.S. Thesis, West Virginia University, Morgantown, WV, 86 pp.

Isaacson, P.E., J. Hladil, J-W. Shen, J. Kalvoda, E. Diaz Martinez, and G. Grader, 1999. Late Devonian glaciation in Gondwana: setting the stage for Carboniferous eustasy. Subcommission on Devonian Stratigraphy, Dec. 1999, Newsletter No. 16, p. 37-46. 
Kammer, T.W. and T.W. Bjerstedt, 1986. Stratigraphic framework of the Price Formation (Upper Devonian-Lower Mississippian) in West Virginia.

Southeastern Geology, v. 27, no. 1, p. 13-33.

Laird, W.M., 1941. The stratigraphy of the Upper Devonian and Lower Mississippian In southwestern Pennsylvania. Pa. Topogr. Geol. Surv. Prog. Rep., 126: 23pp.

Lavin, P.M., D.L. Chaffin and W.F. Davis, 1982. Major lineaments and the Lake Erie-Maryland crustal block. Tectonics, v. 1, p. 431-440.

Matchen, 2003. Personal Communication. West Virginia Geological Survey.

Newberry, J.S., 1870. Report on the progress of the Geological Survey of Ohio in 1869. Ohio Division of Geological Surv., 176 p.

Parrish, J.B. and P.M. Lavin, 1982. Tectonic model for kimberlite emplacement in the Appalachian Plateau of Pennsylvania. Geology, v. 10, p. 344-347.

Pashin, J.C. and F.R. Ettensohn, 1995. Reevaluation of the Bedford-Berea sequence in Ohio and adjacent states: forced regression in a foreland basin. GSA Special Paper 298. 68 p.

Pepper, J.F., W. de Witt, Jr., and D.F. Demarest, 1954. Geology of the Bedford Shale And Berea Sandstone in the Appalachian Basin. U.S. Geol. Surv., Prof. Pap. 259, 109 pp.

Phalen, W.C., 1910. Johnstown folio, Pennsylvania. US Geological Folio 174, 15 p.

Potter, P.E., J.H. DeReamer, D.S. Jackson, and J.B. Maynard, 1983. Lithologic and environmental atlas of Berea Sandstone (Mississippian) in the Appalachian Basin. Appalachian Geol. So., Special Pub 1, 159 pp.

Reger, D.B., 1927. Pocono stratigraphy in the Broadtop Basin of Pennsylvania. GSA, v. 38, p. 397-410.

Roen, J.B., 1968. A transcurrent structure in Fayette and Greene Counties, Pennsylvania, in Geological Survey research 1968, Chapter C, U.S. Geological Survey Professional Paper 600-C, p. C149-C152.

Rogers, M.R., and T.H. Anderson, 1984. Tyrone-Mt. Union cross-strike lineament of Pennsylvania: a major Paleozoic basement fracture and uplift boundary. AAPG Bulletin, v. 68, p.92-105.

Root, S.I. and D.M. Hoskins, 1977. Lat $40^{\circ} \mathrm{N}$ fault zone, Pennsylvania: a new interpretation. Geology, v. 5, p. $719-723$.

Sandberg, C.A., J.R. Morrow, and W. Ziegler, 2002. Late Devonian sea-level changes, catastrophic events, and mass extinctions, in Catastrophic Events and Mass Extinctions: Impacts and Beyond, Koeberl, C. and K.G. MacLeod, eds. Geological Society of America Special Paper 356, p. $473-487$.

Stevenson, J.J., 1878. The Upper Devonian rocks of southwestern Pennsylvania. Am. Journal of Science, v. 15, p. 423.

Tomastik, T.E., 1996, Play Mde: Lower Mississippian-Upper Devonian Berea and equivalent sandstones, in The Atlas of Major Appalachian Gas Plays, J.B. Roen and B.J. Walker, eds., West Virginia Geological and Economic Survey, Pub. V-25, p. 56-62. 
Van Tassel, J. 1994. Evidence for orbitally-driven sedimentary cycles in the Devonian Catskill delta complex, in Tectonic and Eustatic Controls on Sedimentary Cycles, J.M. Dennison and F.R. Ettensohn, eds., p. 121-131.

Wagner W.R., and W.S. Lytle, 1976. Greater Pittsburgh region revised surface structure and its relation to oil and gas fields. Pennsylvania Geologic Survey, $4^{\text {th }}$ ser., Information Circular 80 , $20 \mathrm{p}$.

Wagner, W.R, 1971. Growth faults in Cambrian and Lower Ordovician rocks of western Pennsylvania. AAPG Bulletin, v. 60, p. 414-427.

White, I.C., 1881. The geology of Erie and Crawford Counties. Pennsylvania Bureau of Topographic and Economic Survey, Second Series, Report XXI, p. 94-96. 


\section{Appendix}

\section{Cross-Section Well Data}
$\underline{\text { API \# }}$
$\underline{\text { Well Name }}$
$\underline{\mathrm{API} \#}$
$\underline{\text { Well Name }}$

\section{A-A' Section}

$\begin{array}{lll}\text { 1. } & 3705120442 & \text { W. Herrington \#1 } \\ \text { 2. } & 3712925936 & \text { Tom-Morrow, Inc. \#3 } \\ \text { 3. } & \text { Outcrop at Cramer } \\ \text { 4. } & 3706327584 & \text { H. Cameron \#1 } \\ \text { 5. } & 3706333199 & \text { R. Stiffler \#8 } \\ \text { 6. } & 3706329608 & \text { Farmers \& Miners Tr 28 \#8 }\end{array}$

\section{B-B' Section}

$\begin{array}{ll}\text { 1. } & 3705121244 \\ \text { 2. } & 3712924724 \\ \text { 3. } & 3712922758 \\ \text { 4. } & 3712922972 \\ \text { 5. } & 3712920628 \\ \text { 6. } & 3712920615 \\ \text { 7. } & 3712900338 \\ \text { 8. } & 3712920627 \\ 9 . & 3712921717 \\ \text { 10. } & 3712924424 \\ 11 . & 3712924993 \\ 12 . & 3712924426 \\ 13 . & 3712922729 \\ 14 . & 3712920173 \\ 15 . & 3712924819 \\ 16 . & 3712921136 \\ 17 . & 3706328048 \\ 18 . & 3706327479 \\ 19 . & 3706333411 \\ 20 . & 3706328670 \\ 21 . & 3706322577 \\ 22 . & 3706323489 \\ 23 . & 3706322204 \\ 24 . & 3706328493\end{array}$

\section{C-C' Section}

1. $\quad 3712921370$

2. 3712924788

3. 3712924705

4. 3712925143

5. 3712920707

6. JW 143

7. JW 20

8. JW 104

9. JW 277

10. 3712924837

11. 3706324430

12. 3706326639

13. 3706300093

14. 3706333193

15. 3706326930

16. $\quad 3706333272$

17. 3706332998

\section{D-D' Section}

$1 . \quad 3700300752$

2. $\quad 3700300751$

3. 3700321261

4. 3700320063

5. $\quad 3712922047$

6. 3712925002

7. 3712924891

8. 3712924699

9. $\quad 3712924829$

10. 3700527174

11. 3700526652

12. 3700527121

13. 3700527128

14. 3700520747

15. 3706324993
D. Wells \#2

J. Lenart \#3

P. Eisaman \#2

A. Burnett \#2

M. Ruggiero

Oakford Storage

Oakford Storage

Oakford Storage

Oakford Storage

A. Stine \#7

W. Repine \#3

F. Boden \#4

G. Abel \#1

R. Greene \#5

K. Lewis \#1

A. Kinter \#3

FNB in Indiana \#6
M. Vankirk \#1

J. Finney \#1

Con. Rail Corp. \#2

M. Burke

W. Elwood \#1

Germroth \#3

Aikens \#2

H. McCullough \#2

J. Glass \#5

H. Bier \#4

R. Geiger \#4

D. Smith \#2

J. Bleakney \#2

A. Beers \#1

G. Brown \#1 


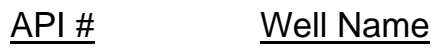

\section{E-E' Section}

$\begin{array}{lll}\text { 1. } & 3700321519 & \text { Penn Hills \#1 } \\ \text { 2. } & 3712900360 & \text { T. Kowaluk \#1 } \\ \text { 3. } & 3700501291 & \text { L. Cherry \#1 } \\ \text { 4. } & 3700501295 & \text { R. Shoemaker \#1 } \\ \text { 5. } & 3700525655 & \text { R. Bowser \#2 } \\ \text { 6. } & 3700527493 & \text { P. Stubrick \#2 } \\ \text { 7. } & 3700502297 & \text { A. Bowser \#1 } \\ \text { 8. } & 3700522336 & \text { R. Ellenberger \#2 }\end{array}$

\section{F-F' Section}

\begin{tabular}{lll} 
1. & 3700501295 & R. Shoemaker \#1 \\
2. & 3700524872 & W. Rimmel \#1 \\
3. & 3700527121 & D. Smith \#2 \\
4. & 3706332566 & J. Smith \#2 \\
5. & 3706326639 & F. Boden \#4 \\
6. & 3706328670 & T. Henry \#2 \\
7. & 3706326745 & J. Zoldak \#1 \\
8. & \multicolumn{2}{l}{ Outcrop at Cramer }
\end{tabular}

$\underline{\text { API \# }} \underline{\text { Well Name }}$

\section{G-G' Section}

1. 3700321519 Penn Hills \#1

2. $3700300766 \quad$ W. Barnett \#1

$\begin{array}{lll}3 . & 3712922047 & \text { W. Elwood \#1 }\end{array}$

4. JW $104 \quad$ Oakford Storage

5. $3712922729 \quad$ Keystone S.P. \#2

6. PNG \# 4405 Sample Log

7. Outcrop at Cramer

\section{$\underline{\mathrm{H}-\mathrm{H}^{\prime} \text { Section }}$}

1. 3700527493

P. Stubrick \#3

2. 3706324993

G. Brown \#1

3. 3706333272

4. 3706322204

5. 3706333199

A. Kinter \#3

C. Bence

R. Stiffler \#8 